\title{
Chromosome and flow cytometric studies of urinary bladder cancer
}

Citation for published version (APA):

Smeets, A. W. G. B. (1987). Chromosome and flow cytometric studies of urinary bladder cancer. [Doctoral Thesis, Maastricht University]. Rijksuniversiteit Limburg. https://doi.org/10.26481/dis.19870703as

Document status and date:

Published: 01/01/1987

DOI:

10.26481/dis.19870703as

Document Version:

Publisher's PDF, also known as Version of record

\section{Please check the document version of this publication:}

- A submitted manuscript is the version of the article upon submission and before peer-review. There can be important differences between the submitted version and the official published version of record.

People interested in the research are advised to contact the author for the final version of the publication, or visit the DOI to the publisher's website.

- The final author version and the galley proof are versions of the publication after peer review.

- The final published version features the final layout of the paper including the volume, issue and page numbers.

Link to publication

\footnotetext{
General rights rights.

- You may freely distribute the URL identifying the publication in the public portal. please follow below link for the End User Agreement:

www.umlib.nl/taverne-license

Take down policy

If you believe that this document breaches copyright please contact us at:

repository@maastrichtuniversity.nl

providing details and we will investigate your claim.
}

Copyright and moral rights for the publications made accessible in the public portal are retained by the authors and/or other copyright owners and it is a condition of accessing publications that users recognise and abide by the legal requirements associated with these

- Users may download and print one copy of any publication from the public portal for the purpose of private study or research.

- You may not further distribute the material or use it for any profit-making activity or commercial gain

If the publication is distributed under the terms of Article $25 \mathrm{fa}$ of the Dutch Copyright Act, indicated by the "Taverne" license above, 


\section{Chromosome and flow cytometric studies of urinary bladder cancer.}

Proefschrift

ter verkrijging van de graad van doctor in de geneeskunde aan de

Rijksuniversiteit Limburg te Maastricht, op gezag van de Rector Magnificus, Prof. Dr. F.I.M. Bonke, volgens het besluit van het College van Dekanen, in het openbaar te verdedigen op 3 juli 1987 om 16.00 uur.

door

Antonius Wilhelmus Godefridus Beatrix SMEETS geboren te Limbricht in 1941. 
Promotores: Prof. Dr. J.P.M. Geraedts R.L.

Prof. Dr. F.M.J. Debruyne K.U.N.

Referenten: Prof. Dr. F.T. Bosman R.L.

Dr. F.C.S. Ramaekers K.U.N.

This study was made possible thanks to the financial support of "Stiching Ziekenhu isapotheek en Klinisch Laboratorium Venray" and of "Psychiatrisch Centrum Venray".

Cover design : Peel Design Ventay

Layout : Chris Voskamp Mastricht

Printing office : Schrijen-Lippertz b.w. Voerendaal 
Nichts ist geworden, alles ist stets im Werden; in dem ewigen Strom der Veränderung ist kein Stillstand.

Goethe

To: Winy

Caroline, Laura and Lidwien. 


\section{Contents}

Chapter I Introduction Page

Chapter II Chromosomal analysis of bladder cancer. 11 Technical aspects.

Chapter III Comparison of tissue disaggregation techniques of transitional cell bladder carcinomas for flow cytometry and chromosomal analysis.

Chapter IV Tissue specific markers in flow cytometry of urological cancers. III.

Comparing chromosomal and flow cytometric DNA analysis of bladder tumors.

Chapter V Grading in superficial bladder cancer.

Cytogenetic classification.

Chapter VI Chromosomal analysis of bladder cancer. II.

A practical method.

Chapter VII Chromosomal analysis of bladder cancer. III.

Nonrandom alterations.

Chapter VIII General discussion.

Chapter IX Summary, samenvatting.

Acknowledgements

Curriculum vitae 


\section{Chapter I}

\section{Introduction}

\section{Frequency, diagnosis and prognosis of bladder cancer.}

Urinary bladder tumors can be divided in epithelial (about $98 \%$ ) and non-epithelial (about $2 \%$ ) tumors. The epithelial tumors include three types: Transitional cell carcinoma (TCC), Squamous cell carcinoma and Adenocarcinoma. In the western world, the frequency of these three types is: $95-98 \%, 1-3 \%$ and $1-2 \%$, respecrively [26].

The mortality of bladder cancer patients in the Netherlands in 1984 was for males 10.4 out of 100,000 and for females 3.4 out of $100,000[5]$.

This means that each year in the Netherlands about 1000 patients die due ro bladder cancer. Death risk increases with age, while mortality increases strikingly after the age of 60 years.

For TCC classification the criteria of histological grade and the depth of infilitration into or through the bladder wall ( = tumor stage) are used. The W.H.O. [55] has proposed a classification in three grades, i.e. G1, G2, G3, while the U.I.C.C. [21] introduced a staging system, indicating the depth of infiltration in the bladder wall, ranging from Ta to $\mathrm{T} 4$ (see addendum).

Superficial carcinomas (stage Ta and T1) generally are treated with transurethral(electro-)resection (TURT), whether or not followed by intravesical chemotherapy. Patients with these tumors have a five year survival rate of about $80 \%$ [36]. Deeply invasive carcinomas (stage T2, T3 and T4) need radical therapy (radiation therapy and/or cystectomy). The five year survival rate of these patients is about $40 \%$ for $\mathrm{T} 2$ tumors and declines to about $6 \%$ for tumors growing through the bladder wall, regardless of the forms of treatment employed $[24,36]$.

The majority of patients presenting with bladder tumor for the first time are staged as Ta (40\%) or T1 (27\%) [9]. Between 10 and 20 percent of the Tamors develop into less differentiated and or invasive tumors ( $\mathrm{T} 1$ or higher). About $30 \%$ of the T1 tumors will infiltrate to deeper layers. This behavior cannot be predicted with the current staging and grading systems. Tumors with identical histopathology are reported to vary significantly in their subsequent clinical course. Therefore, the clinical behavior of a certain tumor is hard to predict for each individual patient [9, 10].

A well known disturbing factor with respect to prediction is the discrepancy existing among pathologists in grading bladder tumors $[16,26,35,40]$.

From the foregoing it may be obvious that in addition to the current histopathological data more information about the biology of bladder cancer is needed for better management of the patients. In this respect it is of real importance to distinguish those Ta tumors which will infiltrate to stage T 1 or deeper, from the non-infiltrating ones and also those T1 tumors which are able to invade into deeper layers, in spite of the therapy applied. It is established that chromosomal studies and estimations of DNA content may contribute to the assessment of biological properties correlative with the prognosis of an individual patient with bladder cancer $[12,27]$. 


\section{Chromosomes and cancer.}

In 1914 Boveri published the hypothesis that a change in chromosome constitution is a prerequisite for cancer development. To test this hypothesis it was necessary to know the exact chromosome number of normal somatic cells. Owing to technical progress in 1956 Tijo and Levan and shortly afterwards Ford and Hamerton described the definite chromosome number of normal cells [40].

In 1960 Nowell and Hungerford established in the leukemic cells of patients with Chronic Myelocytic Leukenia (CML) a striking abnomal small chromosome, the so-called Philadelphia chromosome [40]. This is the first onset of a cascade of chromosomal data of cancer patients.

The need for an accurate nomenclature for human chromosomes resulted in the furst convention, to establish an international system for human cytogenetic nomenclature, held in Derver in 1960. This was followed by conferences in London in 1963, Chicago in 1966 and Paris in 1971.

Around 1970 chromosome banding techniques were introduced. These staining techniques visualise various intrachromosomal bands and/or regions of varying intensity, specific for the species. Since that time it is relatively easy to recognize the individual chromosomes and their structural abnormalities, if sufficient metaphases of adequate quality are present. The bulk of cytogenetic data presently available (more than 5000 cases with malignant disorders) is derived from various hematological malignancies. Solid tumors, quantitatively the largest group of human tumors, constitute less than $10 \%$ of the cases described [34]. This paucity of data in solid tumors attests to difficulties in obtaining adequate numbers of analyzable metaphases. Besides, the karyotypes of solid tumors generally are very complex in comparison with those of leukemia, and therefore very difficult to correlate with various biological, pathological and clinical aspects of these tumors $[43,50,5354]$.

In 1965 Shigematsu [44] was the first to study the chromosomes of transitional cell carcinome of the bladder. He found a relation between the number of chromosomes and the histological type.

Comprehensive studies confirmed the positive correlation between invasion of the tumor and the increasing chromosome count $[27,47]$.

Next to numerical aberrations of the karyotype of bladder cancer, structural aberrations, on behalf of their unrecognizability called "marker chromosomes" were revealed [13, 14, 39]. The presence of marker chromosomes indicates a poor prognosis with respect to recurrence and progression of the tumor $[14,32,48]$. However, also in the absence of markers, recurrence was observed [11].

At the beginning of our study, in 1980 , practically no new data regarding chromosome abnormalities in bladder had been presented during the last ten years. This was largely due to difficulties in disaggregation of the tumor specimens, low mitotic activity and the poor quality of the metaphases $[6,18,19,40,52]$. At that time Sandberg $[40,41]$ stipulated that it was imperative that the studies should be extended to a much larger series of patients at a variety of medical centers around the world, to obtain a body of data that would make it possible to establish the usefulness of the cytogenetic picture in the diagnosis, therapy and prognosis of cancer of the bladder. Direct preparations of the metaphases from tumor cells i.e. without previous cell culture, is preferred. Although 
culturing of the cells provides more recognizable chromosomes, it also implies the risk of selecting some cell types and chromosomal changes during culture time $[40,52]$.

Non-random karyotypic changes in some solid tumors were emphasized, for example interstitial deletion of chromosome $13 \mathrm{q} 14$ in retinoblastoma and of $11 \mathrm{p} 13 \mathrm{in}$. Wilms' tumor $[2,46]$. In an extensive study of bladder tumors published in 1984 [19] no specific chromosome abnormalities could be obtained after direct examination of the tumor specimens, due to insufficient quality of the preparations. Primary karyotypic changes are possibly related to the basic etiology of the disease. Secondary changes, that originate in a later stage of tumor growth, may play a crucial role in the biology of such tumors, and influence their invasiveness, metastatic spread and response to therapy $[42,57]$.

Establishing chromosomal aberrations is of great importance with respect to the study of the location of oncogenes. For example, the oncogene $\mathrm{c}-\mathrm{Ha}$-ras 1 on chromosome \# 11 has drawn much attention $[30,31,38,45]$. It is also of significance for obtaining insight in the process of oncogenesis $[25,42,57]$.

\section{Estimation of DNA content in bladder cancer.}

Estimation of the relative DNA mass showed that as TCC becomes more aggressive, there is a progressive shift from the modal DNA content to higher values $[8,29,49]$.

For measuring the DNA mass, the two major technical approaches are image cy tometry and the flow cy tometry.

In image cytometry the nuclear DNA-content of 100-200 cells spread on a glass slide and Feulgen stained is analyzed with an imaging system based on the microscope [22, 33]. In flow cytometry, cells are measured in a monodisperse suspension. With this technique, introduced in the mid seventies, thousands of cells can be analyzed per second $[4,33]$. Cytochemical or immunocytochemical probes, such as fluorescent dyes and labeled antibodies, are used to examine the cell properties of interest [33]. For DNA estimation in FCM, the cells can be stained with a fluorochrome, for instance propidium iodide. When this fluorochrome is excited at a specific wave length, light of higher wave length is emitted, proportional to the amount of DNA. The signal per cell is registered and quantitatively analyzed with the DNA content of normal human lymphocytes as standard. As a result of the large number of cells that can be measured, different phases of the cell cycle can be analyzed and evaluated statistically. Therefore, flow cytometric DNA measurements can be used to assess the relative DNA mass and cell kinetic data of a certain tumor $[1,12,20,22,28,51,56]$. Normal DNA contents are characteristic for highly differentiated tumors $[7,29]$ which normally also show low proliferative activity. On the other hand, less differentiated tumors, normally show an abnormal DNA content and moderate or even high proliferative fractions [3, 51].

For DNA estimations of the cell type of interest, labeling with antibodies is possible. Tumors with near diploid and pseudo-diploid chromosome abnormalities cannot be detected by FCM $[17,40,56]$. This may be due to the fact that flow cytometric DNA analysis is often disturbed by the presence of stromal or inflammatory cells in the cell suspensions obtained from these neoplasms. Recent developments in cell biology have led to the identification and characterization of tissue specific proteins which make up part of the cell matrix. These so-called intermediate filament proteins (I.F. P.) have a diameter of $7-11 \mathrm{~nm}$, and can be subdivided into five subgroups according to their protein type. Epithelial cells contain cytokeratins, while for instance mesenchymal cells contain 
vimentin and muscle cells contain desmin [15,37]. By application of antibodies to cytokeratin, the epithelial (numor) cells of TCC can be stained specifically [15]. Immunolabeling of the cell suspension with these antibodies makes it possible to discriminate the epithelial cells from non-epithelial cells that are present in the cell suspension.

\section{Aims of this study.}

The aim of this study was to investigate bladder tumors in search for new diagnostic and prognostic factors. Especially the chromosomes and the DNA content of the tumor cells were examined in order to obtain information about the biological characteristics in addition to the routine histopathological data.

The techniques for obtaining chromosomes available at the beginning of this study did not result in quantitatively and qualitatively sufficient data. The development of a technique for obtaining representative chromosome pictures of the tumor cells was our first goal. In addition we wished a practicable, not-laborious technique. Ultimately, the chromosomes must be identified by means of banding techniques, in order to see whether or nor nonrandom abnormalities in the chromosomes could be determined.

For estimation of nuclear DNA by means of flow cytometry, our second goal in this study, single cell suspensions were needed. Therefore, currently available methods for disaggregation of the solid tumor specimens were compared. The cytometrically obtained results were compared and related to the data of chromosomal analysis. 
Addendum.

List of abbreviations used:

Grading system [55].

G1: Tumor with the least degree of cellular anaplasia, compatible with the diagnosis of malignancy.

G2: Intermediate cellular anaplasia.

G3: Tumor with the most severe degree of anaplasia.

\section{Staging system [2r].}

Ta: The tumor is confined to the epithelial tissue, without infiltration.

T1: The tumor is infiltrated in to the connective tissue. ( $\mathrm{Ta}+\mathrm{Tl}$ are superficial tumors).

$\mathrm{T} 2$ : The tumor is invaded into the superficial muscular tissue.

T3: The tumor is invaded into the deep muscles or into the perivesical fat.

T4: The tumor has reached the adjacent organs.

TURT: Trans Urethral Resection of the Tumor.

FCM: Flow Cyto Metry.

TCC: Transitional Cell Carcinoma.

Some examples of cytogenetic nomenclature:

$47, \mathrm{XY},+21$ : $\quad 47$ chromosomes, $\mathrm{XY}$ sex chromosomes and an additional chromosome \# 21 .

$45, \mathrm{XX},-8: \quad 45$ chromosomes, $\mathrm{XX}$ sex chromosomes and a missing chromosome \# 8 .

$47, \mathrm{XY},+14 \mathrm{p}+:$ Male karyotype with 47 chromosomes including an additional chromosome \# 14 which has an increase in the length of its short arm.

$47, \mathrm{XX},+1 \mathrm{lq}-:$ Female karyotype with 47 chromosomes including an additional chromosome \# 1 which has a loss of the length of its long arm.

deletion (abbreviated del): Loss of a chromosome part.

translocation (abbreviated $\mathrm{t}$ ): Breakage followed by exchange of chromosome material between chromosomes.

triploid: $\quad$ All the chromosomes are present in triplicate i.e. 69 chromosomes ( $3 n$ ). near diploid: The modal number cannot be given as a precise number $(2 n \pm)$.

pseudo-diploid: The number of chromosomes is equal to the diploid number (for human beings 46) but numerical and/or structural aberrations are present. 


\section{References}

1. Baisch $H_{3}$ Onto U, König $K$, Klöppel $G$, Köllemann M, Linden WA (1982): DNA conten of human kidney carcinoma cells in relation to histological grading. Brit J Cancer 45: 878-886.

2. Balaban $G_{\text {, }}$ Gilbert $F$, Nichols $W$, Meadows $A T$, Shields J (I98z): Abnomalities of chromosome 13 in retinoblastomas from individuals with normal constitutional karyotyper.

Cancer Genet Cytogener 6:213-221.

3. Barlogie B, Raber MN, Schunann J, Johnson TS, Drewinko B, Swartzendruber DE, Göhde W, Andreeff $M$, Freireich EJ (1983): Flow cylometry in clinical cancer research. Cancer Res 43: 3982-3997.

4. Bunn PA ir, Carney DN, Gazdar AF, Whang-Peng J, Matthews MJ (1983): Diagnostic and biological implications of flow cytometrie DNA contene anatysis in lung cancer. Cancer Res 43: 5026-5032.

5. Centraal Bureau voor de Statistiek (1986). In: Overledenen naar doodscorzaak, leeftijd en geslacht in het jaar 1984. Uitg. C.B.S. serie AL. Den Haag.

6. Chapelle de la A, Berger $R$ ( 1984 ): Report of the committee on chromosome rearrangements in neoplasia and on fragile sites. Cyrogenet Cell Genet 37: 274-311.

7. Collste LG, Darzynkiewicz Z, Traganos F, Sharpless TK, Sogani P, Grabstald H, Whitmore WF ir, Melamed MR (1980): Flow cylometry in bladder cancer detection and evaluation using acridine orange metachromatic nucleic acid staining of irrigation cytology specimens. J Urol 123:478-485.

8. Cooper EH, Levi PE, Anderson CK, Williams RE (I969): The evolution of tumour cell populations in human bladder cancer. In: The chromosomes in human cancer and leukemia. AA Sandberg (1980). ed. Elsevier-North Holland, New York, pp 458-51.6.

9. Cummings KB (1980): Carcinoma of the bladder: Predictors. Cancer 45: 1849-1855.

10. Cutler SJ, Heney NM, Friedell GH ( 1982 ): Longitudinal study of patients with bladder cancer: factors associated with disease recurrence and progression. In: AUA Monographs, vol. 1. Bladder Cancer, Bonney WW and Prout GR, ed. Willians and Wilkins, Baltimore. Chapter 4, pp. 35-46.

11. Dagg K, Roy JB, Bottomley RH (1980): In: Sandberg AA (1986): Chromosome changes in bladder cancer: Clinical and other correlations. Cancer Gener Cytogenet 19: 163-175.

12. Devonec $M$, Darzynkie wicz $Z$, Whitmore WF, Melamed MR (198r): Flow cyrometry for follow up examinations of conserwatively treated low stage bladder tumors. J Urol 126: 166-170.

13. Falor WH (1971): Chromosomes in noninvaswe papillary carcinoma of the bladder. J Am Med Assoc 216: 791.794 .

14. Falor WH, Ward RM (1978): Prognosis in early carcinoma of the bladder besed on chromosomal analysis. JUrol $119: 44-48$.

15. Feitz WTJ, Beck HLM, Smeets AWGB, Debruyne FMJ, Vooijs GP, Herman CJ, Ranaekers FCS (1985): Tissuc-specific markers in flow cytometry of urological cancers: Cytoketatins in bladder carcinoma. Int I Caneer 36: 349-356.

16. Friedell GH, Bell JR, Burney SW, Soto EA, Tiltman AJ (1976): Histopathology and classification of urinary bladder carcinoma. Unologic Clinics of North Ameriea 3: 53-70.

17. Granberg-Ohnnan I, Tribukait B, Wijkström H, Berlin T, Collste L (1980): Papillary carcinoma of the urinary bladder. A study of chromosomal and cytofluorometric DNA analysis. Urol Res 8: 87-93.

18. Granberg-Öhman I, Tribukait B, Wijkström $\mathbb{H}$, Alim A, Berlin T (1982): Chromosome and DNA cytometric study of a papillary carcinoma of the bladder with a high stemline and numerous double minutes. Cancer Gonet Cytogenet 5: 227-235.

19. Granberg-Ohman I, Tribukait B, Wijkström H(1984): Cytogenetic analysis of 62 transitional cell bladder carcinomas. Cancer Genet Cytogenet 11:69-85.

20. Gustafson H, Tribukait B, Esposti PL (1982): The prognostic value of DNA analysis in primary carcinoma in situ of the urinary bladder. Scand J Urol Nephrol. 16: 141-146. 
21. Harmer MH (ed.) (1978): TNM classification of malignant tumours. Third edion, pp. 113-117, UTCC. Geneva.

22. Herman CJ, Vooijs GP (1982): Flow cytometry in clinical oncology. In: E. Lewy (ed). Advances in pathology. Vol. 2. Pergamon Press, Oxford and New York.

23. Hoshi S, Orikasa S, Imai Y, Agatsurna Y (1980): Fenlgen-deoxyribonucleic ncid values in the cyology of bladder cancer. J Urol 124:601-604.

24. Kieler JF (r984): Invasiveness of transformed bladder epirhelial cells. Cancer Metastasis Reviews 3: 265296.

25. Knudson AG jr (1985): Hereditary cancer, oncogenes, and antioncogenes. Cancer Res 45: 1437-1443.

26. Koss LG (1975): Tumors of the urinary bladder. Ia: Atas of Tumor Pathology, 2nd. series, fasc. 11, pp. 19-4.3. Ed. Armed Forces Institute of Pathology, Washington, D.C.

27. Lamb D (1967): Correlation of chromosome counts with histological appearances and prognosis in transitional-cell carcinoma of bladder. Brit Med J 1 :273-277.

28. Learum OD, Farsund $\mathbf{T}$ (1981): Clinical application of flow cytometry: a review. Cytometry $2: 1-13$.

29. Levi PE, Cooper EH, Anderson CK, Path MC, Williams RE (1969): Analysis of DNA content, nuclear size and cell proliferation of transitional cell carcinoma in man. Cancer 23: 1074-1085.

30. Littlefield JW (1984): Genes, chromosomes, and cancer. J Pediat 104: $489-494$.

31. Martinville de B, Giacalone J, Shilh $C_{\text {, }}$ Weinberg RA, Francke U ( 1983$)$ : Onoogene from human EJ bladder carcinoma is located on the short arm of chromosome 11. Science 219:498.501.

32. Martorana G, Giberti C, Ferrari de M, Calvi P, Ottaggio L, Pescatore D (1983): Cytogenenic analysis of transitional cell carcinoma of the bladder. Clinical implications. Eur Urol 9:28-31.

33. Mayall BH (1986): Cytometry in the clinical Jaboratory: Quo vadis? Ann N Y Acad Sci 468: pp. 1-17.

34. Mitelman F (1986): Clustering of chromosonall break-points in neoplasia. Cancer Genet Cytogener 19: $67-71$.

35. Ooms ECM, Andersson WAD, Alons CL, Boon ME, Veldhuizen RW (1983): Analysis of the performance of pathologists in the grading of bladder tumors. Human Pathology 14: 140-143.

36. Prout GR ir, Griffin PP, Shipley WU (1979): Bladder carcinoma as a systemic disease. Cancer 43: 25:32-2539.

37. Ramaekers FCS, Beck HLM, Vooijs GP, Herman CJ (1984): Flow cylometric analysis of mixed cell populations using intermediate fillament amtibodies. Exp Cell Res 153: 249-253.

38. Rowley JD (r983): Human oncogene locations and chromosome aberrations. Nature 301: 290-291.

39. Sandberg AA (1977): Chromosome markers and progression in bladder cancer. Cancer Res 37: 222-229.

40. Sandberg AA (1980): The chromosomes in human cancer and leukemia. Elsewier-North Holland, New York.

41. Sandberg AA (198I): Chromosome studies in bladder cancer. In: Carcinoma of the bladder, JG Cornelly, ed. Raven, New York, pp 127-141.

42. Sandberg AA (1983): A chromosomal hypothesis of oncogenesis. Cancer Genet Cytogenet 8: 277.285.

43. Sandberg AA (1986): Chromosome changes in bladder cancer: Clinical and other correlations. Cancer Genet Cyrogenet 19:163-175.

44. Shigematsu $S$ ( 1965$)$ : Significance of the chromosomes in vesical cancer. Report of the XIII congress of the societé international d'urologie. Vol 2, pp $111-121$, Livingstone, London.

45. Slamon DJ, de Kernion JB, Verma IM, Cline MJ (r984): Expression of cellular oncogenes in tuman malignancies. Science 224: 256-262.

46. Slater RM, de Kraker J (1982): Chromosome number $\mathbb{1}$ and Wilms' tumor. Cancer Genet Cyrogenet 5 : $237-245$. 
47. Spooner $\mathbf{M E}_{3}$ Cooper EH ( 1972$)$ : Chromosome constitution of Iransitional cell carcinoma of the urinary bladder. Cancer 29: 1401-1412.

48. Summers $\mathrm{JL}$, Falor WH, Ward R (1981): A 10-year analysis of chromosomes in non-invasive papillary carcinoma of the bladder. J Urol 125: 177-178.

49. Tavares AS, Costa J, Carvalho A, de Reis M: Tumour ploidy and prognosis in carcinomas of the bladder and prosiate. In: The chromosomes in buman cancer and leukemia. A S Sandberg (1980). ed. ElsevierNorth Holland, New York, pp 458.516.

50. Trent J, Crickard K, Gibas Z, Goodacre A, Pathak S, Sandberg AA, Thompson F, Whang-Peng J, Wolman $\mathrm{S}$ (1986). Methodologic advances in the cy togenetic analysis of human solid rumors. Cancer Gener Cylogener 19:57-66.

51. Tribukait B, Gustafson H, Esposti PL (1982): The sugnificance of ploidy and proliferation in the clinical and biological evaluation of bladder tumours: A study of 100 untreated cases. Br J Urol 54: 130-135.

52. Wake N, Slocum HK, Rustum YM, Matsui SI, Sandberg AA (1981): Chromosomes and causation of human cancer and leukemia. XLIV. A method for chromosome analysis of solid tumors. Cancer Genet Cyloganer 3: 1-10.

53. Wolman SR (I984): Cytogenetics and cancer. Arch Path Lab Med 108: 15-19.

54. Wolman SR (1986): Cyrogenetic heterogeneiry: Its role in tumor evolution. Cancer Genet Cytogenet 19. $129-140$.

55. World Health Organization (1973): Histological typing of urinary bladder tumours. In: International Histological Classification of T"umours, no. 10, WHO, Geneva.

56. Wijkström H, Granberg-Öhman I, Tribukait B (1984): Chromosomal and DNA patterns in transitional cell bladder carcinoma. A comparative cytogenetic and flow-cy tofluorometric DNA study. Cancer 53:17181723 .

57. Yunis J (1983): The chromosomal basis of human neoplasia. Science 221:227-236. 


\section{Chapter II}

\section{Chromosomal analysis of bladder cancer.}

\section{Technical aspects.}

Wim Smeets', Ruud Pauwets", and Joep Geraedts

'Stichting Ziekenhuisapotheek en Klinisch Laboratorium Venray.

${ }^{2}$ Department of Urology, st. Maartens Hospital, Venlo.

${ }^{3}$ Department of Genetics and Cell Biology of the State University Limburg. 


\section{Abstract}

Of 77 patients with bladder carcinoma, 99 tissue specimens-including tissues of patients with recurrent tumors taken after radiotherapy or cytostatics - were subjected to chromosomal analysis. Of 42 specimens, recognizable metaphases could be obtained after conventional Giernsa staining and in a smaller number after $\mathrm{C}$-and/or $\mathrm{G}$-banding. All except one had abnormalities of the chromosomes. Short-term culnures for 24-48 hrs in RPMI- 1640 plus $15 \%$ fetal calf serum plus penicillin-streptomycin gave better results than a direct technique $\left(30 \mathrm{~min}\right.$ in $0.075 \mathrm{M} \mathrm{KCl}+0.1 \mu \mathrm{g}$ colcemid $/ \mathrm{ml}$ at $37^{\circ} \mathrm{C}$, followed by fixation). In low stage/grade tumors the number of recognizable metaphases obtained after short-term cultures is lower than in higher stage/grade tissue specimens.

\section{Introduction}

Since 1965 several studies have been published on chromosomal abnormalities in bladder tumors [3-8, 13,14, 17-19, 21-23]. We have started a prospective study to see if information can be obtained at a very early stage about the future tumor behavior in superficial bladder carcinoma, based on the presence or absence of chromosomal abnormalities.

Chromosomes of bladder rumors usually were examined without prior cell culture. Cell suspensions were made using various protocols $[4,13]$.

Karyotyping bladder tumors has always been problematic, mainly because of the small amount of recognizable metaphases. Various techniques that ought to increase the number of good metaphases have been published. The results obtained with several of the published techniques are discussed for different stages and grades of tumor in this article.

\section{Materials and methods}

\section{Patients}

Between $1 / 1 / 81$ and $6 / 30 / 83$ material from 77 patients (67 male and 10 female) with a transitional cell carcinoma was subjected to chromosomal examination (Table 1 ). When the first material for cytogenetic examination was obtained, only one patient had been given cylostatic treatment and none of the patients had been subjected to radiotherapy before the first chromosomal analysis. In view of tumor recurrence, a number of patients had been examined two to four times, so that from these 77 patients a total of 99 biopsies of tumorous tissue were available for cytogenetic analysis. Specimens were taken by coldcup biopsies or by transurethral diathermical resection (TURT). One part of the same biopsy went to the pathology laboratory, another to the cytogenetic laboratory.

Table 1

Patients examined.

Tumor stage

$\begin{array}{lrrrrr}\text { Grade } & \text { Ta } & \text { T1 } & \text { T2 } & \text { T3 } & \text { Total } \\ \text { G1 } & 3 & - & - & - & 3 \\ \text { G2 } & 40 & 10 & 2 & 5 & 57 \\ \text { G3 } & - & 5 & 4 & 8 & 17 \\ \text { Total } & 43 & 15 & 6 & 13 & 77\end{array}$


Staging was performed according to the TNM-classification for malignant tumors [26]. In the TNM-system, T stands for the degree of local growth of the tumor, $N$ for the metastasis to lymphatic glands, and $M$ for metastasis (at a wide range into other organs). Ta tumors are confined to the superficial epithelial tissue, without infiltration; T1 tumors infiltrate into the connective tissue below; $\mathrm{T} 2$ tumors invade the superficial muscular tissue; T3 tumors develop into the inner muscular tissue or into the perivesical fat; and T4 tumors grow into adjacent organs.

Ta and $T 1$ tumors remain superficial, in the sense that they have a comparatively good prognosis, but have a high degree of recurrency. In general they can be treated by means of transurethral resection. T2 and T3 tumors have a lethal prognosis of approximately $50 \%$, despite aggressive therapy (cystectomy and/or radiotherapy). T4 tumors are believed to be incurable.

The histologic grading was based on World Health Organization (W.H.O.) recommendations [27]. Grade 1 tumors show hyperplasia but are highly differentiated; grade 2 tumors show moderate polymorfia, nuclear arypia, and hyperplasia of the epithelium; in grade 3 tumors these phenomena are more serious, sometimes to the exten that the tissue is no longer recognizable as urothelial tissue.

\section{Chromosome analysis}

\section{Technical variations tested in the beginning of this study}

Collection and transportation of bladder tissue:

The biopsies were collected and transported in one of the following solutions: Ringerglucose solution, Hanks' solution, or RPMI 1640 medium. All the solutions were at a temperature of $\pm 0^{\circ} \mathrm{C}$ or at roomtemperature, with or without addition of colcemid (between $0.01 \mu \mathrm{g}$ and $10 \mu \mathrm{g} / \mathrm{ml}$ ).

Preparation of cell suspension:

After mincing and scraping the tissues were mixed for $10-30 \mathrm{~min}$ in $0.9 \% \mathrm{NaCl}$ in a magnetic stirrer. After mechanical pretreatment, the tissues were enzymatically treated with the enzymes protease and/or collagenase (Boehringer Mannheim B.V.).

Hypotonic treatment:

Tests were made with: $0.037 \mathrm{M} \mathrm{KCl}$ for $30-120 \mathrm{~min}$ at $37^{\circ} \mathrm{C} ; 0.064 \mathrm{M} \mathrm{KCl}$ for $30-120 \mathrm{~min}$ at $37^{\circ} \mathrm{C} ; 0.7 \%$ sodium citrate [16] and $0.6 \%$ glucose in $0.7 \%$ sodium chloride $/ 0.44 \%$ sodium citrate $(\mathbb{1}: 1)[17]$.

Cell fixation:

Cells were fixed with: $50 \%$ acetic acid [4]; $60 \%$ acetic acid; methanol/acetic acid $4: 1$ or methanol/acetic acid 3:1.

Preparation of slides:

The following techniques were used to prepare slides:

Application of cell suspension on a clean heated slide with 1 drop of $60 \%$ acetic acid already on the slide [2].

As a variation on Croizier's method, the cell suspension was mixed with the acetic acid as it fell onto the slide [11].

Slides were stored in $50 \%$ acetic acid of $4^{\circ} \mathrm{C}$ and the suspension was flame-dried [13]. 
A few drops were placed on clean wet slides, which were kept in distilled water at $4^{\circ} \mathrm{C}$, and then flame or air-dried.

Tissue culture:

After dissociation of the tissue with collagenase, a short-term culture in Leibovitz L-15 medium with $20 \%$ fetal calf serum, $10-20 \mu \mathrm{g}$ porcine insulin/ml, and $16 \mu \mathrm{g}$ glutathione $/ \mathrm{ml}$ was performed [12].

\section{Current method}

The tissue is put into a solution of $0.9 \% \mathrm{NaCl}$ at approximately $0^{\circ} \mathrm{C}$ and within $30 \mathrm{~min}$ a cell suspension is made by mincing and scraping the material as finely as possible.

Treatment of the tumor:

Direct technique involves incubating the tumor material for $30 \mathrm{~min}$ in $0.075 \mathrm{M} \mathrm{KCl}$ plus $0.1 \mu \mathrm{g}$ colcemid/ml at $37^{\circ} \mathrm{C}$ followed by fixation in methanol/acetic acid, 3:1. (Recently, we have also used an incubation period of $2 \mathrm{hrs}$ in RPMI 1640 plus $0.1 \mu \mathrm{g}$ colcemid at $37^{\circ} \mathrm{C}$ prior to hypotonic treatment).

Short-term culture, only used if a good cell suspension can be obtained, involves incubation for 24-48 hrs in RPMI 1640 plus $15 \%$ fetal calf serum and $4 \%$ penicillinstreptomycin $(100 \mathrm{U} / \mathrm{ml}$, respectively $100 \mathrm{\mu g} / \mathrm{ml})$ at $37^{\circ} \mathrm{C}$. Two hours before termination of the culture, $0.1 \mu \mathrm{g} / \mathrm{ml}$ colcemid is added, followed by hypotonic treatment, and fixation as above.

Long-term culture is performed only with cold-cup biopsy material, in the absence of a good cell suspension, in plastic bottles with Ham's F-10 plus 15 , respectively $25 \%$ fetal calf serum $1-4 \mathrm{wk}$ in $5 \% \mathrm{CO}_{2}$ atmosphere.

Treatment of the normal bladder tissue:

Normal bladder tissue is always subjected to a long-term culture, since it is very solid and cannot be easily worked into a cell suspension.

Preparation of slides:

Three or four drops of the cell suspension are placed on clean, wet object slides that have been stored in aqua dest of $4^{\circ} \mathrm{C}$. The preparations are slowly flame-heated and then airdried. The preparations are stained by conventional method with Giemsa.

In those cases where sufficient slides are available and the unbanded preparations show good metaphases, CBG-banding [24] and GTG-banding methods are used [20].

\section{Results}

\section{Technical variations for chromosomal examination}

All the solutions examined produced a worse, or in any case, no better metaphase result than the use of $0.9 \% \mathrm{NaCl}$ at $0^{\circ} \mathrm{C}$.

The use of a magnetic stirrer did not produce a better cell suspension than the conventional technique of mincing and scraping. The use of protease and/or collagenase damaged many cells or resulted in chromosomes with a very fuzzy appearance.

None of the solutions used gave a better spreading of chromosomes than $0.075 \mathrm{M} \mathrm{KCl}$; the optimal time was $30 \mathrm{~min}$.

Use of $60 \%$ acetic acid damaged the chromosomes and had negative effects on banding. The same effect on banding was noted with use of $50 \%$ acetic acid. This fixative did not increase the percentage of recognizable metaphases, as compared to methanol/acetic acid, 
3:1. Methanol/acetic acid, $4: 1$ yielded no better results. Spreading of metaphases after $60 \%$ acetic acid was improved, as compared to methanol/acetic acid, but application of more than $50 \%$ acetic acid reduced the quality of the chromosomes.

Culture after treatment with collagenase only produced some metaphases, when a very large amount of material was available. The number of metaphases, spreading, and quality of chromosomes was worse with this method than after short-term culture with RPMI 1640 , without enzymatic treatment.

\section{Current method}

In 42 of 99 tumors examined with the direct technique or with the short-time culture, recognizable metaphases were found (Table 2). Metaphases were considered recognizable if there were only a few overlaps, if the centromeres were visible, and if the A-G groups could be identified. The number of metaphases varied between three and a large number per tumor, or between 1 and 25 per slide.

Table 2

Number of patients and cases where metaphases were found in relation to $T / G$.

\begin{tabular}{lrrrrrrrrrr}
\hline & ToGo & TaGl & TaG2 & TiG2 & T1G3 & T2G2 & T2G3 & T3G2 & T3T4G3 & Tolal \\
\hline n pat. & 40 & 3 & 40 & 10 & 5 & 2 & 4 & 5 & 8 & 77 \\
ncases & 50 & 4 & 55 & 12 & 7 & 2 & 4 & 5 & 10 & 99 \\
Inc.meta. I & 11 & 2 & 39 & 7 & 6 & 2 & 4 & 4 & 8 & 72 \\
Inc. meta. II & 7 & 0 & 20 & 5 & 4 & 2 & 2 & 2 & 5 & 42
\end{tabular}

$\begin{array}{ll}\text { n pat. } & \text { : number of patients. } \\ \text { nz cases } & \text { : number of cases. } \\ \text { Inc. meta. I } & \text { : Incidence of metaphases with recognizable and/or unrecognizable chromosomes, } \\ \text { Inc. meta. Il } & \text { : Incidence of metaphases with recognizable chromosomes (more than three metaphases per case) } \\ \text { ToGo } & \text { : Normal bladder tissue. }\end{array}$

Of the 50 control experiments performed with normal bladder tissue metaphases were found in 11 cases, of which seven were recognizable: six tissue cultures with $46, \mathrm{XY}$ and one with $46, \mathrm{XX}$. These metaphases were obtained after long-term culture.

Only one tumor (TaG2) showed a normal karyotype, in all other cases there were abnormalities that will be published in a separate report.

In total 78 superficial (Ta-Tl) bladder tumors were examined from 58 patients. Recognizable metaphases were found in 29 tumors $(37 \%)$. A group of 21 deeply infiltrating tumors (T2-T4) from 19 patients showed recognizable metaphases in 13 tumors $(62 \%)$. These numbers include four tissue specimens from three patients with recurrent tumors who received radiotherapy after the first chromosomal analysis and which did not show recognizable metaphases after treatment.

The short-term culture of cold-cup biopsies yielded significantly better metaphases with the deep tumors than with the superficial tumors (Table 3). If we counted the recognizable and/or unrecognizable metaphases, there was no difference in this respect (Table 4). 
Table 3

Recognizable metaphases in superficial and deep tumors in relation to the technique applied.

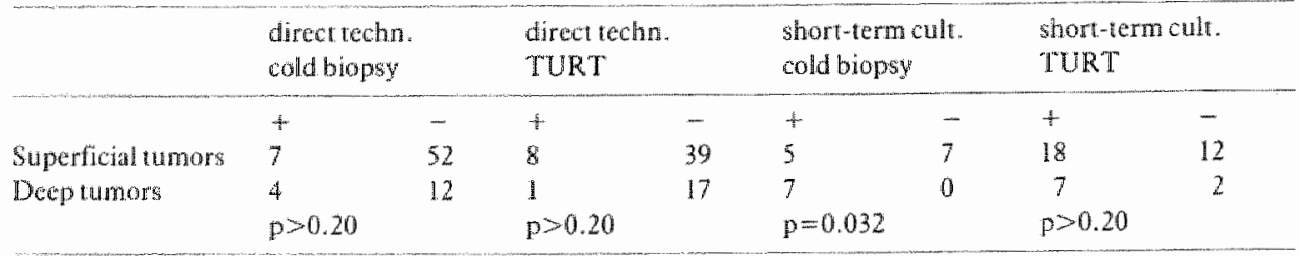

+ : number of cases with recognizable chromosomes.

- : number of cases without recognizable chromosomes.

Table 4

Recognizable and/or unrecognizable metaphases in superficial and deep tumors in relation to the technique applied.

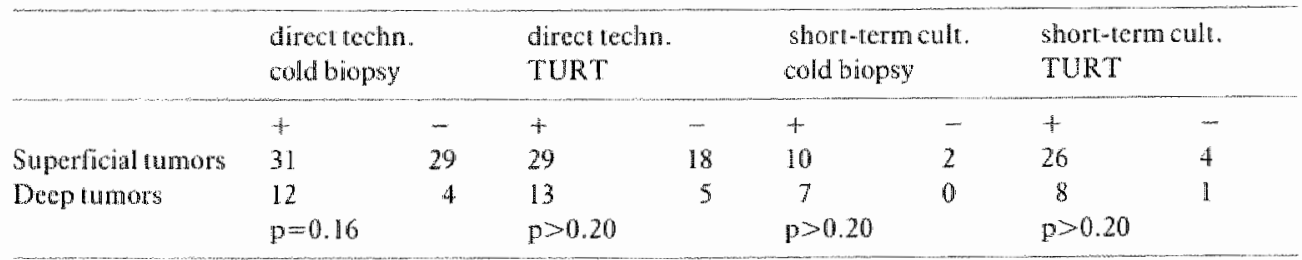

+ : number of cases with recognizable and/or unrecognizable metaphases.

-: number of cases withour metaphases.

If the percentage of metaphases, whether or not they were suitable for further cytogenetic analysis, is related to the technique applied (Table 5), it appears that with the direct technique metaphases are present in $52 \%$ of all cold-cup biopsies, (at least three per biopsy) and in $61 \%$ of the TURT material. When applied to those operations where both cold-cup biopsies and TURT tissues were removed, McNemar's test produces no significant difference in metaphase results with the direct technique $(p>0.20)$.

The use of short-term culture produced metaphases in $94 \%$ of the cold-cup biopsies and in $88 \%$ of the TURT-materials ( $\mathrm{p}>0.20$, McNemar's test).

No difference was observed between either the metaphase production of the direct technique or short-term culture, when applied to cold-cup biopsies and TURT materials. In $12 \%$ of all cold-cup biopsies and in $13 \%$ of the TURT materials recognizable metaphases ( $\geqslant$ three per biopsy) were obtained with the direct technique $\langle p>0.20$, McNemar's test). Recognizable metaphases with the use of short-term culture were found in $63 \%$ of the cold-cup biopsies and in $68 \%$ of the TURT tissues $(\mathrm{p}>0.20$, McNemar's test). McNemars'test, when applied to cold-cup biopsies where both the direct technique and short-term culture is applied, showed significantly more recognizable metaphases with the short-term culture $(p=0.016)$. The sane test applied to TURT-materials, where both direct technique and short-term culture is applied, also showed significantly more recognizable metaphases with the short-term culture $(p<0.001)$. 
Recognizable and/or unrecognizable metaphases in relation to the technique applied.

\begin{tabular}{|c|c|c|c|c|c|c|c|c|}
\hline & \multicolumn{4}{|c|}{ Direct method } & \multicolumn{4}{|c|}{ Shori-termollure } \\
\hline & \multicolumn{2}{|c|}{ cold biopsy } & \multicolumn{2}{|c|}{ TURT } & \multicolumn{2}{|c|}{ cold biopsy } & \multicolumn{2}{|c|}{ TLRT } \\
\hline Rec.t unrec. & $\begin{array}{l}\text { Il cases } \\
85\end{array}$ & $\begin{array}{l}\text { I meta. } \\
44(52)\end{array}$ & $\begin{array}{l}\text { I cases } \\
70\end{array}$ & $\begin{array}{l}\text { nineta } \\
4(61)\end{array}$ & $\begin{array}{l}\text { 1. cases } \\
16\end{array}$ & $\begin{array}{l}\text { when } \\
15(94)\end{array}$ & $\begin{array}{l}n \cos c 5 \\
40\end{array}$ & $\begin{array}{l}\text { he meto } \\
36(88)\end{array}$ \\
\hline Rec. & 85 & $10(12)$ & 70 & $9(13)$ & 11 & $10(63)$ & 4 & $28(68)$ \\
\hline
\end{tabular}

n mela. $\quad$ number of cases with metaphases.

In parentheses is the percentage of cases with metaphases.

Rec. + untec. "metaphases with recognizable and/or unrecognizable chromosomes.

Rec. : metaphases with recognizable chanosomes.

\section{Discussion}

The overall result of recognizable metaphases was $37 \%$ with superficial tumors (Ta-T1) and $62 \%$ with deep infilltrating tumors (T2-T4). This may be related to a lower mitotic frequency in superficial tumors, as discussed by Sandberg [17]. Only by use of short-term culture with cold-cup biopsies did the deeply infiltrating tumors yield significantly more metaphases than superficial tumors (Table 3). However, taking together the unrecognizable and the recognizable metaphases in superficial and deep infiltrating tumors, there is no significant difference (Table 4).

In the majority of cases we could only perform chromosome analysis of superficial tumors with the direct technique, because the tissue specimen was too small $\left(<2 \mathrm{~mm}^{3}\right)$ to perform short-term culture as well. Very solid material, which could not be dispersed easily into a cell suspension, was of no use for short-term culture.

If tumorous tissue is removed during a TURT, the amount of material available for analysis is usually much larger (sometimes more than $1 \mathrm{~cm}^{3}$ ). For short-term culture it hardly matters if the tissue is a cold-cup biopsy or taken by TURT. A large amount of tissue is preferable because it is important to have many slides with many metaphases for banding techniques. After transurethral resection, the tissue becomes partially necrotic as a result of electroresection. This has a negatieve effect on the number of recognizable metaphases. Since the amount of resection material usually is larger, the final result is identical.

Culture of cells of a transitional cell carcinoma in vitro is difficult. [15]. After long-term culture of tumor tissues, only 3 out of 10 tumors yielded recognizable metaphases. The use of the short-term agar culture in the cyrogenetic analysis of human tumors, as mentioned by Hamburger and Salmon [10], has only rarely been reported. The preliminary results as reported by Trent and Salmon [25] demonstrated the potential application of this technique to cancer genetics. Because long-term culture is time consuming and provides poor metaphases (and it is uncertain which cells are growing), we prefer the use of the direct technique and short-term culture.

A comparison of our percentages of metaphases with the results of other investigators is difficult. Often, only recognizable metaphases are given and no mention is made of the number of non-recognizable metaphases or of their total absence. Although there are more metaphases observed in many tumors (Table 5), a great number is unrecognizable because of poor spreading or the fuzzy appearance of the chromosomes. To improve spreading, 
fixation in acetic acid of higher concentration [2], was applied [11, 13]. Although use of $60 \%$ acetic acid afforded better spreading than with methanol/acetic acid 3:1, the chromosomes were thin, elongated, fuzzy, and even showed gaps in the chromatids. Even more important was the finding that after this procedure, banding was almost impossible. Harbott [11] had a similar experience. Flame-drying or air-drying slides provided no improvement in spreading. No improvement was seen when the slides were stored in $50 \%$ acetic acid at $4^{\circ} \mathrm{C}$ or room temperature, or in distilled water of differing temperature. Changing the concentration, the volume, or the kind of hypotonic solution did not give better metaphase spreads.

C-banding was attempted in 42 tumors with recognizable metaphases. Some banding pattern was obtained in 18 cases. In 13 of these the quality was good and in the remaining five cases the chromosomes were very contracted or had a very fuzzy appearance. Gbanding was attempted in 15 tumors. Only three cases were successful, some chromosomes were recognizably banded in eight, and in the remaining four it did not work at all. The following factors may have contributed: the small number of metaphases; the very contracted or fuzzy chromosomes and the poor spreading. Tumor metaphases also might have shown an unexplainable resistance to banding.

It is the experience of many investigators dealing with bladder tumors that banding is a major problem. Atkin et al. [1] were successful in only 12 of 30 cases using C-banding, and a lower success rate using $\mathrm{G}$-banding. The problem with banding might be attributable to the use of the direct technique [22]. Granberg-Ohman et al. [9] state that in spite of the numerous and well spread metaphases, banding was not of good quality. According to Sandberg [19], satisfactory banding analysis has been obtained in only $20 \%-30 \%$ of bladder tumors in the best hands.

\section{Conclusions}

Short-term cultures of the tumor tissues provided a larger percentage and better quality of metaphases than the use of the direct-technique. This applied to both cold-cup biopsies and TURT material. The short-term cultures of cold-cup biopsies yielded significantly more good metaphases in infiltrating tumors (T2-T4) than in the superficial tumors (TaT1).

Long term cultures of tumor material as well as healthy bladder tissues was time consuming and the number of cultures with sufficient metaphases was limited. The successful cultures of normal tissue always revealed only normal karyotypes.

After the use of $60 \%$ acetic acid to obtain well-spread metaphases, the chromosomes were no longer suitable for G-banding. Banding was also difficult after fixation with methanol/ acetic acid $3: 1$.

Technical improvements are necessary to obtain better spread metaphases without disturbing the chromosomes.

The authors thank Drs R. Schapers and R. Retera, pathologists and Drs J. Scheepers, urologist, for their cooperation. Miss D. van Gog for technical assistance. Miss C. Bouten for typing the manuscript. Drs Ederveen-Lucas for translation. Drs P. Peer M.S.A. Nijmegen for statistical evaluation and the board of directors of the Z.A.L.V. and Psychiatric Hospital Venray for financial support. 


\section{References}

1. Atkin NB, Baker MC (I977): Abnormal chromosones and number I heterochomatin variants tevealed in C-banded preparanons from 13 bladder carcinomas. Cytobios 18: 101-109.

2. Croizier RH (1968): An acetic acid dissociation, air-drying technique for insect chromosomes, with atectolactic orcein staining. Srain Tech 43:171-173.

3. Falor WH (r97 1 ): Chromosomes in noninvasive papillary carcinoma of the bladder. J Am Med Assoc 216:791-794.

4. Falor WH, Ward RM (1973): DNA banding patterns in carcinoma of the bladder. J Am Med Assoc 226:1322-1327.

5. Falor WH, Ward RM (I976): Cytogenetic analysis: A potential index of recurrence of enrly carcinonia of the bladder, IUrol 115:49-52.

6. Falor WH, Ward RM (1977): Prognosis in well-differentiated non-invasive carcinoma of the bladder based on chromosomal analysis. Surg Gynecoll Obstet 144:515-518.

7. Falor WH, Ward RM (1978): Irognosis in early carcinoma of the bladder based on chromosomal analysis. JUrol 119:44-48.

8. Granberg-Öhman, I, Tribukait B, Wijkström H, Berlin T, Collste LG (1980): Papillary carcinoma of th: urinary bladder. A study of chromosomal and cytofluoromerric DNA analysis. Urol Res 8:87-93.

9. Granberg-Öhnan I, Tribukait B, Wijkström H, Alim A, Berlin T (1982): Chronosome and DNA cytometric study of a papillary carcinoma of the bladder with a high stemline and numerous double minutes. Cancer Genet Cylogenet 5:227-235.

10. Hamburger AW, Salmon SE (1977): Primary bioassay of human tumor stem cells. Science 197:461-463.

11. Harbott J (I98I): Urologische universitatsklinik. Marburg a.d.L. (personal communication).

12. Kusyk CJ, Edwards CL, Arrighi FE, Romsdahl MM (1979): Improved method for cytogenetic studies of solid rumors. J Natl Cancer Inst 63:1199-1203.

13. Lamb D (1967): Correlation of chromosome counts with histological appearances and prognosis in uransitional-cell carcinoma of bladder. Br Med J 1:273-277.

14. Martorana G, Giberti C, Ferrari de M, Calvi P, Ottaggio L, Pescatore D (1983): Cytogencic analysis of transitional cell carcinoma of the bladder. Clinical implications, Eur Urot 9:28-31.

15. Niell HB, Soloway MS (rg83): Use of the tumour colony assaty in the eqaluation of pationts with bladder cancer. Br ] Urol 55:271-274.

16. Pathak S, (1980): Cyrogenetic analysis in human breast tumors. Cancer Genet Cytogenet 1:281-289,

17. Sandberg AA (1977): Chromosome markers and progression in bladder cancer. Cancer Res 37:2950-2456

18. Sandberg AA (1980): The Chromosomes in Humar Cancer and Leukemia. Eilsevier-North Holland, New York, pp. 503-510.

19. Sandberg AA (1982): Chromosomes in bladder cancer In: American Urological Association. Seminar on bladder cancer. Monogr. 1, Bladder Cancer. Bonney WW, w. Williams and Wilkins, Baltimore, pp. 81-94.

20. Seabright $\mathbf{M}$ (1971): A rapid banding technique for human chromosomes. Lancet ii:971-972.

21. Shigematsu $\mathbf{S}$ (1965): Significance of the chromosomes in vesical cancer. In: International Socicty of Urology, 13th Congress, Vol. 2, E and $\$$ Livingstone, London, pp. 111-121.

22. Spooner ME, Cooper EH (1972): Chromosome constitution of transirional cell carcinoma of the wrinary bladder. Cancer 29:1401-1412.

23. Summers JL, Falor WH, Ward R (1981): A 10-year analysis of chromosomes in non-invasiwe papillary carcinoma of the bladder. J Urol 125:177-178.

24. Sumner AT (1972): A simple technique for demonstrating centric heterochromatin. Exp Cell Res $75: 304$. 306. 
25. Trent JM, Salmon SE ( 1980 ): Potential application of a buman tumor stem cell bioassay to the cylogenetic assement of human cancer. Cancer Genen Cytogenen 1:291-296.

26. Union International Contre le Cancer (1978): TNM Classiffation of Malignant Tumours. 3rd edition, UICC, Geneva.

27. World Health Organization (1973): Histological lyping of urinary bladder tumours. In: International Histological Classification of Turnours, no. 10, WHO Genewa. 


\section{Chapter III}

\section{Comparison of tissue disaggregation techniques of transitional cell bladder carcinomas for flow cytometry and chromosomal analysis.}

A.W.G.B.Smeets, R.P.E. Pauwels ${ }^{2}$, H.L.M. Beck, W.F.J. Feitz, J.P.M. Geraedts" F.M.J. Debruyne, L. Laarakkers', G.P. Vooijs, F.C.S. Ramaekers".

"Stichting Ziekenhuisapotheek en Klinisch Laboratorium Venray.

2 Department of Urology, st. Maartens Hospital, Venlo.

${ }^{3}$ Department of Anatomic Pathology, Radboud Hospital of the Catholic University Nijmegen,

${ }^{4}$ Department of Urology, Radboud Hospital of the Catholic University Nijmegen.

5 Department of Genetics and Cell Biology of the State University Limburg. 


\section{Abstract}

DNA index (DI) measurements and chromosomal analysis of 42 transitional cell carcinomas were done after mechanical and after enzymatical disaggregation of the tumor specimens. The results obtained with these different disaggregation techniques were compared in the 33 cases (79\%) which showed recognizable chromosomes. The enzymatically obtained cell suspensions could not be used for chromosomal analysis after short term culture of 24 hours. In four cases, the DI after enzymatical treatment could not be estimated. In most cases, the DI obtained from the tumor cells was similar for both aggregation techniques, with the exception of four cases of enzymatically treated cell suspensions in which the DI could not be estimated. The average DI of the aneuploid tumors was 13\% higher than the corresponding chromosome count.

In 19\% of the aneuploid tumors the proportion of aneuploid cells could not be measured after enzymatical treatment. In the remaining suspensions the proportion of diploid cells was higher after enzymatical disaggregation than after mechanical treatment. It is concluded that for flow cytometric and direct chromosomal analysis of bladder tumors, the mechanical disaggregation technique is most suitable.

Key terms: tissue disaggregation, bladder carcinoma.

\section{Introduction}

Flow cytometry and chromosomal analysis have been described as important methods for the examination of bladder carcinomas [10-12,23]. The degree of ploidy and the proliferative activity of the iumor can be used as additional parameters in patient treatment $[3,20]$. The same significance may be adjudged to the detection of chromosomal abnormalities in tumor specimens $[6,15,17,18]$. Essential for proper flow cytometric (FCM) investigations and chromosomal analyses are optimal single-cell suspensions of the (malignant) tissues under examination. Current methods for disaggregation of tumor specimens include mechanical and enzymatical treatment of the tissue. It has been reported that the proportions of aneuploid cells in cell suspensions obtained by mechanical disaggregation were higher than in those obtained after enzymatical disaggregation $[5,8]$. Differences may also be due to different enzymatical methods [4].

In this study the DNA content of tumor cells in the GO/G1 phase after mechanical and enzymatical disaggregation was measured. These data were correlated with histological as well as cytogenetical data of the same transitional cell carcinomas. The percentages of diploid cells in the GO/GI phase present in the cell suspensions after the two disaggregation techniques were compared. The effects of disaggregation procedures and the usefulness of the different cell suspensions for FCM and chromosomal analysis are discussed.

\section{Materials and methods}

Forty-two tumor specimens, 38 primary and 4 recurrent ones, from 31 male and 7 female successive patients with carcinoma of the urinary bladder were investigated. They could be divided into tumor stages as folows: $14 \mathrm{pTa}, 11 \mathrm{pTl}, 17 \mathrm{pT}$-p T4 tumors. The tissues were collected after transurethral resections. 
One part of each biopsy was used for pathologic examination, while the remaining part was used for chromosomal and flow cytometric studies.

Clinical staging of the tumor was done according to the rules of Union International Contre le Cancer [13], and grading was done according to the WHO system [24]. Staging and grading were as follows: $\mathrm{pT}$ a tumors are noninvasive; $\mathrm{pT} 1$ tumors do not show invasion into the muscularis; $\mathrm{pT} 2-\mathrm{pT} 4$ tumors show invasion from superficial muscularis to neighbouring organs. Grade 1 tumors show hyperplasia but are highly differentiated. Grade 2 tumors show moderate polymorphia, nuclear atypia and hyperplasia of the epithelium. Grade 3 tumors show severe abnormalities, sometimes to the extent that the tissue is no longer recognizable as urothelial tissue.

\section{Disaggregation procedures}

The specimens were collected and transported in the following medium: $10 \mathrm{ml}$ RPMI 1640 plus $17 \%$ fetal calf serum (FCS), $50 \mu \mathrm{g}$ gentamicin/ml, $100 \mathrm{U}$ penicillin/ml and $100 \mu \mathrm{g}$ streptomicin $/ \mathrm{ml}$.

For mechanical disaggregation, the tissue was minced by scraping and cutting in a petridish and was filtered through a $100 \mu \mathrm{m}$ nylon filter (Ortho Diagnostic Systems, Beerse, Belgium). The cell suspensions were divided in two parts, one for short-term or long-term chromosomal analysis and the other one for flow cytometry. For the latter purpose, the cells were centrifuged at $400 \mathrm{~g}$ for 7 minutes. Then, $70 \%$ ethanol $\left(-20^{\circ} \mathrm{C}\right)$ was added rapidly to the cell pellet under constant shaking. The final concentration was about $3 \times 10 \mathrm{cel} l \mathrm{~s} / \mathrm{ml}$ ethanol. Ar this stage, the fixed cells could be stored several weeks at $-20^{\circ} \mathrm{C}$.

For enzymatical disaggregation, the specimen was cut into small fragments and incubated $1-2 \mathrm{hr}$ at $37^{\circ} \mathrm{C}$ in the medium with $0.8 \mathrm{~g} / 100 \mathrm{ml}$ collagenase II (Worthington, Freehold, NJ). The cell pellet was washed with medium, filtered, and centrifuged. This washing step was repeated three times, and the cell suspension was divided into two parts, one for short-term or long-term chromosome culture and the other one for flow cytometry. For the latter purpose, the cells were fixed in $70^{\%} \%$ ethanol, at $-20^{\circ} \mathrm{C}$, as mentioned above.

For direct chromosomal analysis, the specimens were collected and transported in $10 \mathrm{ml}$ sodium citrate $+0,5 \mu \mathrm{g}$ colcemid/ml and disaggregated mechanically.

\section{Chromosomal analysis}

For chromosomal analysis one or more of the following techniques were applied: Direct method (in preparation). Briefly: The tissue specimens were collected and disaggregated as mentioned above. After incubation in Hanks BSS again, a colcenid solution was added ( $2 \mu \mathrm{g} / \mathrm{ml}$ Hanks BSS). Hypotonic treatment was done with a mixture of $6 \mathrm{ml} \mathrm{FCS}$ and $24 \mathrm{ml} 0.052 \mathrm{M} \mathrm{KCl}$. Fixation was performed with acetic acid-methanol $3: 7$.

Short term culture [19]. Briefly: The cells obtained after the disaggregation procedures as described were incubated for $24 \mathrm{hrs}$ in the medium. Metaphase arrest with colcemid 0.1 $\mathrm{\mu g} / \mathrm{ml}$ was followed by hypotonic treatment with $0.075 \mathrm{M} \mathrm{KCl}$ and fixation in methanolacetic ancid $3: 1$.

Long term culture [9]. Briefly: The cells obtained after the disaggregation methods as described were incubated for 1-2 weeks in flasks containing the culture medium. 
Methotrexate synchronization was done, followed by colcernid arrest, hypotonic treatment, and fixation.

All slides were stained with Giemsa. C-banding and, when enough appropriate metaphases were available, $\mathrm{G}$-banding was performed.

Metaphases were photographed and analyzed according to the standard rules.

From every tumor, the chromosomal range, the modal number, the distribution according to ploidy $(n=23 \pm 11,2 n=46 \pm 11,3 n=69 \pm 11$ etc. $)$ and the presence of (double) minutes and marker chromosome(s) were recorded (see Table 1). In those cases in which metaphases were obtained with the direcr method as well as with the short-term culture the results were pooled.

Our detailed chromosomal observations will be published elsewhere (in preparation).

\section{Flow cytometry}

For DNA measurements the sample was stained with the fluorochrome propidium iodide (PI) and thereafter the cells were treated with RNAse and inspected microscopically. Cell analysis was performed using a cytofluorograph $5 \mathrm{OH}$ (Ortho Instruments, Westwood, MA).

PI was excited at $488 \mathrm{~nm}$ with an argon ion laser (Spectra Physics, Mountain View, CA). Fluorescence was measured using a 630-nm long-pass filter. All data were stored on a PDP 1.1/34 computer (Digital Equipment Corporation, Marlboro, MA) for subsequent data analysis.

Chicken red blood cells (CRBC) were used as an internal standard, while human lymphocytes were used as an external standard. Ploidy measurements conformed to the method described by Jakobsen [14].

Samples with a DNA-index (DI) of more than 1.13 or lower than 0.89 (= mean \pm 3 S.D. of measurements of normal bladder cells) after mechanical disaggregation and more than 1.12 or lower than 0.88 after enzymatical disaggregation were classified as abnormal. Measurements of percentage of $\mathrm{GO} / \mathrm{G} 1$ diploid cells conformed to the method described by Baisch et al. $[1,2]$.

\section{Results}

\section{Normal bladder tissue ( 7 cases)}

The DI after mechanical disaggregation was 1.01 (range 0.95-1.07) with a s.d. $=0.04$. After enzymatical disaggregation it was 1.00 (range 0.93-1.09) with a s.d. $=0.04$. The percentage of $\mathrm{Go} / \mathrm{G} 1$ diploid cells after mechanical disaggregation was 82.5 (range $75.4-91.4$ ) with a s.d. $=3.6$. After enzymatical disaggregation it was 86.7 (range 71.1 94.5) with a s.d. $=4.7$.

\section{Bladder tumors}

Of the 42 tumor specimens, analyzable metaphases were obtained in 33 cases ( $79 \%)$. The metaphases were obtained with the direct method and/or the short-term culture of $24 \mathrm{hrs}$ and in two cases only after a long-term culture. Enzymatical disaggregation did not result in analyzable metaphases after 24 hrs culture, but in two out of five cases the long-term culture was successful. The DI could be obtained in all the specimens after mechanical 
disaggregation and in 36 cases after enzymatical treatment. The mean coefficient of variation (c.v.) for the $\mathrm{GO} / \mathrm{G} 1$ peak was 5.8 (range 3.5-9.3) after mechanical

disaggregation and 6.2 (range 2.4-9.4) aftur enzymatical disaggregation, respectively. As the study was restricted to the 33 cases with recognizable metaphases the DI of both pTI and also of two pT2-pT4 tumor suspensions could not be examined after enzymatical treatment of the specimens. In five suspensions, the percentage of diploid cells in the $\mathrm{GO} /$ G1 phase could not be estimated after enzymatical disaggregation of the specimens, owing to a large amount of debris.

Table 1

Flow cytometric and chromosome data of cell suspensions disaggregated by mechanical and enzymatical procedures in relation to stage and grade.

Chromosomat nesilts

\begin{tabular}{|c|c|c|c|c|c|c|c|c|c|c|c|c|}
\hline Tumor & $\begin{array}{l}\text { Age } \\
\text { (years) }\end{array}$ & Sex & $\mathrm{pT} / \mathrm{G}$ & $\mathrm{D} \mathrm{H}^{1}$ & $\mathrm{Ol}^{2}$ & $\mathrm{mn}$ & range & $2 n$ & $3 n$ & 41. & $5 n$ & $\operatorname{dm}$ \\
\hline 1 & 70 & $\mathrm{M}$ & $\mathrm{TaG}_{2}$ & 1.00 & 0.99 & 46 & $45-47$ & 10 & & & & \\
\hline 2 & 72 & $\mathrm{M}$ & $\mathrm{TaG}_{2}$ & 1.03 & 1.03 & 46 & $34.48^{1}$ & 30 & & & & \\
\hline 3 & 53 & $M$ & $\mathrm{TaC}_{2}$ & 0.99 & 0.98 & 43 & $40-45$ & 40 & & & & \\
\hline 4 & 70 & $\mathrm{M}$ & $\mathrm{TaG}_{2}$ & 1.02 & 0.99 & 46 & $38-47$ & 20 & & & & \\
\hline 5 & 64 & $\mathrm{M}$ & $\mathrm{TaC}_{2}$ & 1.11 & 1.14 & 43 & 40.90 & 19 & 1 & 5 & & \\
\hline 6 & 54 & $M$ & $\mathrm{TaGl}^{2}$ & 1.05 & 0.97 & 46 & $46^{b}$ & 6 & & & & \\
\hline 7 & 70 & $M$ & $\mathrm{TaG2}$ & 1.02 & 0.97 & 46 & 46 & 10 & & & & \\
\hline 8 & 78 & $M$ & $\mathrm{TaG} 2$ & 0.97 & 1.05 & 46 & $39-87$ & 32 & 1 & 2 & & \\
\hline 9 & 66 & $M$ & $\mathrm{TaC}_{2}$ & 1.01 & 0.97 & 45 & 36.47 & 15 & & & & \\
\hline 10 & 61 & $M$ & $\mathrm{TaG} 2$ & 1.06 & 1.05 & 46 & 46 & 10 & & & & \\
\hline$\|$ & 44 & $M$ & $\mathrm{TaC2}$ & 1.03 & 0.98 & 46 & $36-46$ & 27 & & & & \\
\hline 12 & 48 & $M$ & $\mathrm{TaG}_{2}$ & 1.00 & 1.00 & 45 & $37-46$ & 15 & & & & \\
\hline 13 & 86 & $M$ & $\mathrm{~T} 1 \mathrm{G} 2$ & 1.45 & 1.61 & 69 & $40-90$ & 11 & 43 & 2 & & + \\
\hline 14 & 50 & $M$ & $\mathrm{~T} 1 \mathrm{G}$ & 2.37 & 2.19 & 87 & $65-90$ & & 3 & 4 & & \\
\hline 15 & 55 & $M$ & $\mathrm{~T} 1 \mathrm{G}$ & 1.09 & 1.03 & 44 & $37-47$ & 40 & & & & \\
\hline 16 & 84 & $F$ & $\mathrm{~T} 1 \mathrm{G} 2$ & 1.1 & 1.05 & 4.6 & 42.50 & 10 & & & & \\
\hline 17 & 53 & $M$ & $\mathrm{~T} 1 \mathrm{G} 2$ & 0.98 & 1.00 & 43 & $35-60$ & 14 & 1 & & & \\
\hline 18 & 62 & $\mathrm{Fi}^{\mathrm{i}}$ & $\mathrm{T} 1 \mathrm{G} 2$ & 2.11 & 2.14 & 87 & $44 m 87$ & 2 & 1 & 15 & & \\
\hline 19 & 86 & $\mathrm{~F}$ & $\mathrm{~T} 1 \mathrm{G} 2$ & 1.94 & $-{ }^{4}$ & 80 & $75-86$ & & 16 & 4 & & \\
\hline 20 & 75 & $M$ & TIG & 1.96 & -3 & 73 & $44-73$ & 3 & 4 & & & \\
\hline $2 \mathrm{~L}$ & 73 & $M$ & $12 \mathrm{G} 2$ & 1.76 & 1.80 & $46(70)$ & $43-75$ & 27 & 6 & & & \\
\hline 22 & 71 & $M$ & $\mathrm{~T} 2 \mathrm{G} 3$ & 1.69 & 1.87 & $46(70)$ & 42.70 & 5 & 3 & & & \\
\hline 23 & 74 & $\mathrm{~F}$ & $12 \mathrm{G}_{3}$ & 2.37 & 2.50 & 98 & $46-110$ & 3 & 1 & 15 & 1 & \\
\hline 24 & 54 & $M$ & $\mathrm{~T} 2 \mathrm{G} 3$ & 1.68 & 1.69 & 73 & $65+73$ & & 14 & & & \\
\hline 25 & 75 & $M$ & $\mathrm{~T} 2 \mathrm{G}_{2}$ & 1.95 & 1.87 & 85 & 59.93 & & 22 & 28 & & \\
\hline 26 & 53 & $M$ & $\mathrm{~T} 2 \mathrm{G} 3$ & $\begin{array}{l}1.74 \\
(3.28)\end{array}$ & 1.70 & 68 & $54-117$ & 2 & 8 & & 3 & \\
\hline 27 & 64 & $M$ & $T 3 C_{2}$ & 2.00 & $-{ }^{a}$ & 74 & $45 \times 78$ & 4 & 6 & & & \\
\hline 28 & 67 & $F$ & $\mathrm{~T} 3 \mathrm{G}$ & 1.83 & 1.76 & 77 & $46-87$ & 4 & 24 & 4 & & \\
\hline 29 & 67 & $\mathrm{~F}$ & $\mathrm{~T} 3 \mathrm{G} 3$ & 1.74 & 1.79 & 77 & $53-89$ & 1 & 28 & 2 & & \\
\hline 30 & 70 & $M$ & $\mathrm{~T} 3 \mathrm{G}$ & 1.85 & 1.70 & 73 & $53-76$ & 2 & 23 & & & \\
\hline 31 & 74 & $M$ & $\mathrm{~T} 3 \mathrm{G} 3$ & 1.84 & -4 & 73 & $62-40$ & & 38 & 2 & & \\
\hline 32 & 73 & $\mathrm{Fi}$ & $\mathrm{T} 4 \mathrm{G} 3$ & 1.61 & 1.57 & 69 & $46 \% 120$ & 14 & 18 & 3 & & $-f^{*}$ \\
\hline 33 & 66 & $M$ & $\mathrm{~T}_{4} \mathrm{G}$ & 1.67 & 1.65 & 69 & $65 \cdot 125$ & & 13 & $y$ & 5 & \\
\hline
\end{tabular}

DI", DNA index after mechanical disaggregation; $\mathrm{DI}^{2}$, DNA index after enzymatical disaggregation; mn, modal number; $\mathrm{dm}$, double minutes; $M$, marker chromosome(s); $a$, not measured; $b$, long term-culure. 


\section{pTa tumors ( 12 cases)}

The DI of all the cases was within the normal range $(=2 \mathrm{c})$ after mechanical disaggregation (table 1). After enzymatical treatment the DI of one case (No. 5) was slightly higher than normal.

The modal chromosome number was diploid in eight cases, including the two in which only long-term cultures were applied, and hypodiploid in four cases. These 12 samples were obtained from ten patients. Two specimens had a wide range in chromosome number (Nos. 5 and 8 ).

Marker chromosomes of different types could be recognized in six cases. In three out of 12 cases, neither numerical nor structural abnormalities could be observed.

By comparison of the percentages of diploid cells present in the single cell suspensions after the two disaggregation methods were applied, no significant difference was seen $(\mathrm{p}=$ 0.41 ; Wilcoxon test, paired case). The mean percentage of diploid cells after mechanical disaggregation was 85.9 (s.d. $=4.5$ ), and after enzymatical disaggregation it was 84.8 (s.d. $=3.8$ ).

\section{pTr tumors ( 8 cases)}

The DI after mechanical disaggregation was normal in three cases and varied from about $3 \mathrm{c}$ to nearly $5 \mathrm{c}$ in the other ones. After enzymatical treatment the DI was normal in the same three cases as above. In three other cases the DI varied from about $3 \mathrm{c}$ to about $4 \mathrm{c}$. In two cases the DI could not be measured, owing to marked reduction of the fraction of $\mathrm{GO} /$ GI cells. Comparison of the DI's obtained with the two disaggregation methods showed that the results were identical within a $10 \%$ deviation, with the restriction that after enzymatical treatment in two cases the DI could not be measured.

The modal chromosome number varied from hypodiploid to near-tetraploid. All the specimens had an abnormal chromosome constitution. Especially in the aneuploid tumors, a wide range was seen, and cells with different levels of ploidy were present. Marker chromosomes of different types were present in six out of eight cases. In one specimen a lot of double minutes could be observed.

The DI in four out of five cases with an abnormal DNA value was higher than the corresponding chromosome counts. This difference varied from $12 \%$ (No. 18) to about $23 \%$ (No. 20).

Comparison of the percentages of diploid cells present in the single cell suspension after mechanical (mean 42.1 with a $\mathrm{s} . \mathrm{d} .=30.3$ ) or enzymatical $($ mean 65.8 with a $\mathrm{s.d} .=21.3$ ) treatment showed that after enzymatical treatment significantly more diploid cells were present in the cell suspension (Fig. 1$)(p=0.04)$. From two suspensions these percentages could not be estimated owing to bad quality of the cell suspensions. 

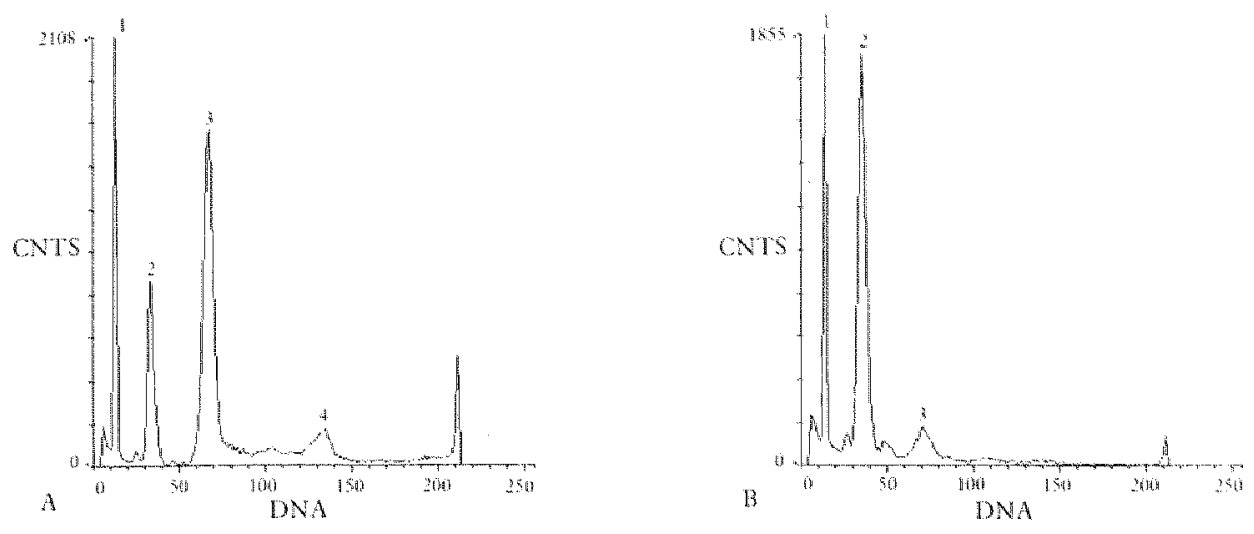

Fig 1.

DNA histogram of a T 1 G 3 bladder carcinoma (No. 20) after mechanical (A) and after enzymatical (B) disaggregation of the tissue specimen.

A) 1, CRBC-peak; 2, normal GO/GI phase; 3, abnormal GO/G1 Plase (DI 1.96); 4, G. M phase of the cells indicated under peak 3 .

B) 1, CRBC-peak; 2, nomal GO/G1 phase; 3, the abnomal cells in B can not be indicated, since ubey seem to be masked by the $\mathrm{G}_{2} \mathrm{M}$-phase cells of the normal cells.

\section{pT2-pT 4 tumors ( 13 cases)}

The DI after mechanical disaggregation varied from about $3 \mathrm{c}$ to nearly $5 \mathrm{c}$. In one case (No. 26) two different populations were found. After enzymatical treatment the DI could not be estimated in two cases, owing to strong reduction of the $\mathrm{GO} / \mathrm{Gl}$ cells. In the remaining cases the DI varied from about $3 \mathrm{c}$ to $5 \mathrm{c}$. Also in this group of tumors, the DI's obtained with the two disaggregation methods were identical.

The modal chromosome number varied from diploid to about tetraploid. All the specimens showed an abnormal chromosome constitution. It is conspicuous that most infiltrating tumors (pT3-pT4) showed a modal number in the triploid range.

Marker chromosomes of different types could be observed in ten out of 13 cases. In one specimen many double minutes were seen.

The DI as estimated by flow cytometric analysis was in all cases higher than the corresponding chromosome counts. This difference ranged from $4 \%$ (No. 29) to about $24 \%$ (No. 30), with an average of $12 \%$. Comparison of the percentages of diploid cells obtained after mechanical treatment (mean 26.9 with a s.d. $=13.0$ ) and after enzymatical treatment (mean 62.7 with a s.d. $=17.2$ ) showed that after enzymatical treatment significantly more diploid cells were present in the suspension $(p=0.004)$. In two suspensions these percentages could not be obtained, owing to bad quality of the cell suspensions.

\section{Cell morphology}

Four cell suspensions, one from a non-infiltrating tumor and three from deeply infilt trating tumors, obtained after mechanical or enzymatical disaggregation were examined for cell morphology. The percentage of epithelial cells was reduced after enzymatical treatment. The enzymatical treatment also had a degenerative effect on tumor cells. 


\section{Discussion}

Flow cylometric investigations and chromosomal analyses need optimal single-cell suspensions. Bladder tumor tissue is often very adherent, and a single-cell suspension is often difficult to prepare by mechanical disaggregation. Therefore, enzymatical disaggregation is frequently used. In this study, the usefulness of mechanically and enzymatically obtained cell suspensions for flow cytometry and chromosomal analysis were compared.

Flow cytometry gave data in all cases examined after mechanical disaggregation. In four of the 33 cases compared, the DI could not be examined after enzymatical disaggregation. The DI of the $\mathrm{GO} / \mathrm{GI}$ phase of the tumor cells after both disaggregation methods was, with a marginal exception, identical.

The DI of the pTa tumors was 2c. In superficially infiltrating tumors (pT1), normal as well as abnormal DNA values were found, whereas in deeply infiltrating tumors only abnormal DNA values were seen. This agreed with others [23].

For chromosomal analysis, analyzable data were obtained in 33 of the 42 cases (79\%). In our hands, it appeared that enzymatically obtained cells were not suitable for the 24 -hour short-term culture. For long-term culture we agree with Wake et al, [22] who found that, after enzymatical disaggregation, a large number of cells attached themselves to the bottom of the culture flasks. We do not prefer this long-term culture, since it is time consuming and it is uncertain whether all the cells present in the initial cell suspensions are able to grow, and if so, it is uncertain whether they grow at the same speed. For this reason we remain in doubt about the representativity of the chromosome constitution obtained after long-term culture. Owing to techrical improvements at this moment, it is possible to obtain chromosomes in more than $90 \%$ of the tumor specimens, with a direct technique, after mechanical disaggregation.

In cell suspensions, epithelial as well as non-epithelial cells are present. For this reason, in order to reduce this risk of false-negative karyotypes, a great number of cells must be

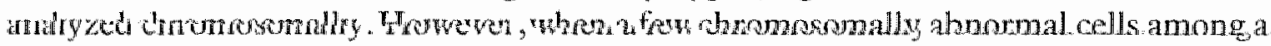
large number of normal ones are found, it may be assumed that these cells represent the malignant part of the tissue, as soon as two or more cells show the same abnormalities. The mean value of the DNA content of abnormal p T1-pT4 tumor cells, as estimated flow cytometrically, was $13 \%$ above the value expected from the corresponding chromosome count, assuming that the average chromosomal DNA is $1 / 46$ of the mean DNA content of the normal diploid genome. In normal bladder tissue a $12 \%$ deviation is accepted (DI $=2 \mathrm{c}$ $\pm 3 \mathrm{s.d}$.). When this percentage also is used in aneuploid tumors, the DI measured is still above or in the upper range of the DI expected on the basis of the chromosome count. This difference has been described earlier $[11,23]$. Contribution of double stranded RNA is excluded, since a RNAse treatment was applied before flow cytometric analysis of the cell suspensions. A disproportionate increase of large chromosomes, as present in many tumors, can not explain this difference, as the ratio of large to small chromosomes did not deviate from normal diploid cells [21]. Premature chromosome condensation also focused attention on the need to explain this difference [3]. However, no integral explanation for the difference between the DNA values and cytogenetic data could be obtained and therefore this phenomenon needs further investigation.

Another difference between both methods of analysing the cells was noted with respect to the chromosomal range. By means of FCM analysis, cumors with two or more abnormal 
cell lines were rarely observed. It is possible that cells with an abnomal DNA walue were masked by the $S$-phase in flow cytomerric examination. Chromosomal analysis especially of infiltrating tumors, showed a great range in the chromosome counts. Possible this represents stem-line(s) with side-line(s), however, without banding analysis it is impossible to discriminate among such lines. Nevertheless, it remains worthwhile to examine the clinical significance of this wide distribution.

When the percentages of diploid cells obtained with the two disaggregation techniques were compared, it appeared that in the aneuploid tumors a higher percentage of diploid cells was present in the cell suspension after enzymatical treatment. In other words, the percentage of aneuploid cells was higher after mechanical disaggregation than after enzymatical disaggregation. This difference is probably due to an increase in the release of stromal cells into the cell suspension as a result of collagenase treatment. The possibility can not be excluded that other enzymes would yield other results. Also, many tumor cells were degenerated. Frankfurt et al. [8] found that in 14 of the 16 aneuploid tumors the proportion of aneuploid cells was higher in the suspensions that were obtained mechanically. In the remaining two cases, enzymatically obtained suspensions contained a slightly higher percentage of aneuploid cells. In three of their cases, the aneuploid cells, which were observed in the DNA histogram after mechanical disaggregation, were not evident in the histogram of enzymatically obtained cell suspensions from the same tumors. In our study, in all of the 15 tumors with an abnormal DI that could be compared, the percentage of aneuploid cells after mechanical treatment was higher than after enzymatical disaggregation. Moreover, in four $(=19 \%$ ) cases of infiltrating tumors, the percentage of aneuploid cells could not be obtained after enzymatical treatment.

Small numbers of aneuploid cells in enzymatically obtained cell suspensions are easily masked by the released non-epithelial cells. Also, in multiparameter analyses, for instance in the determination of percentages of $S$ and $G_{2} M$ phase, stromal and inflammatory cells disturb these estimations. To avoid this problem, mechanical disaggregation can be applied, although a better procedure for discriminating the epithelial from non-epithelial cells is to apply cytokeratin antibodies in a twodimensional FCM analysis $[7,16]$.

From our results we conclude that disaggregation of bladder tumor tissue with the enzyme collagenase II is not suitable for short-term chromosome culture. For flow cytometric analysis it does not influence the DI, as compared to mechanical disaggregation, but in four cases the DI could not be estimated after enzymatical treatment. The percentage of diploid cells is higher after enzymatical treatment of aneuploid tumor specimens. Mechanical disaggregation must therefore be preferred to enzymatical methods in the preparation of cell suspensions to be used for FCM and chromosomal analysis without previous culture.

\section{Acknowledgements}

The authors thank Drs R. Schapers and R. Retera, pathologists, and Drs J. Scheepers, urologist (Venlo), for their cooperation; Mr A. Reintjes M.S.A. Nijmegen, for statistical evaluation. Miss. C. Bouten for typing the manuscript, and the board of directors of the Z.A.L.V. and Psychiatric Hospital Venray and the st. Maartens Hospital Venlo for funancial support. 


\section{Literature cited}

1. Baisch H, Göhde $W$, Linden WA Analywis of PCP data to determine the fraction of cells in the various phases of the cell cycle. Radiat Erviron Biophys 12:31-39, 1975.

2. Baisch H, Otto U, König $K$, Kloppel $G$, Köllermann $M$, Linden WA: DNA content of the human kidney carcinoma cells in relation to histological grading. Br J Cancer 45:878-886, 1982.

3. Barlogie B, Raber MN, Schumann J, Johnson TS, Drewinko B, Swartzendruber DE, Göhde W, Andreeff $M_{n}$ Freireich $\mathbb{E}$ ]: Flow-cytomery in clinical cancer rescarch. Cancer Res 43:3982-3997, 1983.

4. Bijman JTh, Wagener DJTh, van Rennes $H$, Wessels JMC, yan den Broek $\mathbb{P}$ : Flow cytometric evaluation of cell dispersion from human laead and neck tumors. Cytometry 6:334-341, 1985

5. Chin JL, Pontes JE, Frankfurt OS: Flow cytometric desoxyribonucleic acid analysis of primary and metastatic human renal cell carcinoma. J Urol (Paris) $133: 582 \times 585,1985$.

6. Falor WH, Ward RM: Prognosis in early carcinoma of the bladder based on chromosomal analysis. J Urol (Paris) $119: 4448,1978$.

7. Feitz WFI, Beck HLM, Smeets AWGB, Debruyne FMJ, Vooijs GP, Herman CJ, Ramaekers FCS: Tissue-specific markers in flow cytometry of urological cancers. Cyrokeratins in bladder carcinoma. In J Cancer $36: 349-356,1985$.

8. Frankfurt OS, Slocum HK, Rostum YM, Arbrick SG, Pavelic ZP, Petrelli N, Huben RP, Pontes JE, Greco WR: Fiflow cytometric analysis of DNA aneuploidy in primary and metastatic human solid tumors. Cylonetry 5:71-80, 1984.

9. Gibas Z, Prout GR, Connolly JG, Pontes JE, Sandberg AA: Nonrandom chromosomal changes in transitional cell carcinoma of the bladder. Cancer Res 44:1257-1264, 1984.

10. Granberg Öhman I, Tribukait B, Wijkström H, Berlin T, Collste LG: Papillary carcinoma of the urinary bladder. A study of chromosomal and cy tofluorometric DNA analysis. Urol Res 8:87-93, 1980.

11. Granberg-Öhman I, Tribukait B, Wijkstrỏm H, Alim A, Berlin T: Chronosome and DNA cytometric study of a papillary carcinoma of the biadder with a high stemline and nunerous double minutes. Cancer Genet Cytogenet 5:227-235, 1982 .

12. Granberg-Ohman I, Tribukait B, Wijkström H: Cyrogenesic analysis of 62 transitional cell bladder carcinomas. Cancer Gener Cytogener 11:69-85, 1984.

13. Harmer $M H_{\text {, }}$ ed): TNM classilication of makignant tumours. Third edition, Geneva, UICC, 1978 pp $113-$ $\| 17$.

14. Jakobsen $\mathbf{A}$ : the use of trout crythrocytes and human lymphocynes for standardization in flow cytometry. Cytometry 4:16]-165, 1983.

15. Pauwels R, Smeets W, Geraedts J, Debruyne F: Cytogenetic analysis in urothelial cell carcinoma. J Unol (Paris) $137: 210-215,1987$.

16. Ramakers FCS, Beck JLM, Vooujs GP, Herman CJ: Flow-cytometric analysis of mixed cell populations using intermediate filament antibodies. Exp Cell Res $153: 249.253,1984$.

17. Sandberg AA: Chromosome markers and progression in bladder cancer. Cancer Res 37:2950-2956, 1977.

18. Summers JL, Falor WH, Ward R: A 10-year analysis of chronosomes in non-invasive papillery carcinoma of the biander. JUrol (Paris) $125: 177-178,1981$.

19. Smeets W, Pauwels R, Geraedts J: Chronosomal analysis of bladder cancer: Technical Aspects. Cancer Gencr Cytogenet 16:259-268, 1985

20. Tribukait B, Gustafson M, Esposti P-L: The significance of ploidy and proliferarion in the clinical and biological evaluation of bladder cumours: A study of 100 untreated cases. Br J Urol 54:130-135, 1982.

21. Tribukait B, Granberg-Öhman 1, Wijkström H: Flow cytometric DNA and cytogenetic studies in human umors: A comparison and discussion of the differences in modal values obrained by two methods. Cylometry 7: $194 \cdot 199,1986$. 
22. Wake N, Slocum HK, Rustum YM, Matsui S, Sandberg AA: Chromosones and causation of human cancer and leukemia. XLIV. A method for chromosome analysis of solid rumors. Cancer Gener Cyrogenet $3: 1-10,1981$.

23. Wijkstrom $H$, Granberg-Ohman $I$, Tribukait $\mathbb{B}$ : Chromosomal and DNA patterns in transitional cell bladder carcinoma. A comparative oy genetic and now-cytofluorometric DNA study. Cancer 53:1718$1723,1984$.

2*. World Health Organization: Histological typing of urinary bladder tumours. In: International Histological Classification of Tumours No 10. WHO, Genewa, 1973. 



\section{Chapter IV}

\section{Tissue specific markers in flow cytometry of urological cancers.}

III. Comparing chromosomal and flow cytometric DNA analysis of bladder tumors.

A.W.G.B. Smeets, R.P.E. Pauwels ${ }^{2}$, J.L.M. Beck , J.P.M. Geraedes, F.M.J. Debroyne, L. Luarakkers', W.F.J. Feitz ${ }^{5}$, G.P. Vooijs ${ }^{3}$, F.C.S. Ramaekers $s^{3}$.

'Stichting Ziekenhuisapotheek en Klinisch Laboratorium Venray.

2 Department of Urology, st. Maartens Hospital, Venlo.

${ }^{3}$ Department of Anatomic Pathology, Radboud Hospital of the Catholic University Nijmegen.

${ }^{4}$ Department of Genetics and Cell Biology of the State University Limburg.

${ }^{5}$ Department of Urology, Radboud Hospital of the Catholic University Nijmegen. 


\section{Abstract}

Thirty-seven transitional-cell carcinomas (TCC) of the urinary bladder were analyzed by DNA flow cytometry (FCM). After labeling of the cell suspensions with antibodies to cytokeratin, the cytokeratin positive cells and the non-epithelial cytokeratin negative cells could be analyzed separately.

After estimation of $\mathrm{S}$ - and $\mathrm{G}_{2} \mathrm{M}$ phase, 3 of the 17 cases (18\%) with a normal DNA index showed elevated proliferative levels, among cytokeratin labeled suspensions only. Of these 17 cases, 14 showed chromosomal abnormalities. The remaining 20 cases were abnormal irrespective of the technique used.

Although immuno-labeling of tumor cells for cytokeratin in FCM increases the sensitivity of this method in detecting aneuploid tumors or tumors with high proliferation fractions, the discriminating power of chromosomal analysis of TCC is greater than FCM.

\section{Introduction}

Chromosomal analysis as well as DNA flow cytometry have been described as important methods for studying the biology of urinary bladder cancers (Granberg-Öhman et al., 1980, 1982, 1984; Wijkström et al, 1984). An increase in chromosome numbers has been reported to correlate with invasiveness and loss of differentiation (Granberg-Öhman et al., 1980; Lamb, 1967; Spooner and Cooper, 1972). Furthermore, marker chromosomes are regarded as characteristics of clinically more aggressive bladder tumors (Falor and Ward, 1978; Sandberg, 1980, 1982; Summers et al., 1981).

DNA measurements of transitional cell carcinomas (TCC) showed that an abnormal DNA value is a sign of malignancy (Levi et al., 1969; Collste et al., 1980; Tribukait etal., 1982; Barlogie et al., 1983; Frankfurt et al., 1984). DNA values obtained through FCM and proliferative data are useful tools for diagnosis, management and prognosis of parients with bladder tumors (Devonec et al., 1981; Gustafson et al., 1982; Klein et al., 1982; Chin et al., 1985). Normal modal chromosome number and DNA index obtained by FCM are in good agreement with each other in TCC. However, tumors with near diploid chromosome counts and pseudo-diploid abnormalities can apparently not be detected by FCM (Granberg-Öhman et al., 1980; Wijkström et al., 1984). This may be due to the fact that the DNA flow cytometric analysis of carcinomas is often disturbed by the presence of stromal or inflammatory cells in the cell suspensions obtained from these neoplasms. Recently the use of antibodies to cy tokeratin and FCM has made it possible to distinguish between the different tissue types present in such suspensions (Ramaekers et al., 1983, 1984). Virtually all carcinomas, including TCC, contain cytokeratins, contrary to diploid stromal and inflammatory cells. Therefore, immuno-labeling of tumor cell suspensions with cytokeratin antibodies makes possible the analysis of epithelial cells by FCM (Feitz et al., 1985). In this way, the proliferative fraction among tumor cells can be estimated apart from stromal and inflammatory cells. This method also allows cy tokeratin-negative diploid cells to be used as internal standards for calculation of the DI values of the tumor cells. This cannot be done without this labeling procedure, since in that case diploid carcinoma cells cannot be distinguished from non-epithelial cells.

In this study, data on chromosomal analysis and on FCM DNA measurements in tissue specimens from patients with TCC of the urinary bladder, with and without application of antisera to cytokeratin, were compared. The proportion of tumor cells in S-phase, estimated after application of these antisera was correlated with tumor stage. 


\section{Materials and methods}

Thirty-seven tumor specimens, 33 primary and 4 recurrent cases, from 26 male and 7 female patients with TCC of the urinary bladder were succesfully analyzed. According to tumor stage, they could be divided as follows: 14 cases of p Ta, 11 of pT 1 and 12 of pT2pT4.

The cissues were collected following transurethral resection. One part of each biopsy specimen was used for pathologic examination, while the rest was used for chromosomal and flow cytometric studies with and without application of antisera against cytokeratin. Clinical staging of the tumor was done according to the UICC TNM system (Harmer, 1978) and grading according to the WHO system (WHO, 1973).

\section{Chromosomal analysis.}

One or both of the following techniques were used:

Direct method.

The tissue specimens were collected and transported in $10 \mathrm{ml} 0.5 \%$ sodium citrate +0.5 $\mu g$ colcemid/ml $(1 \mathrm{hr})$. They were disaggregated by scraping and cutting in a Petri dish and filtered through a 100 unlon filter (Ortho Diagnostic Systems, Beerse, Belgium). After incubation in Hanks' balanced salt solution (BSS obtained from Gibco, Paisley, U.K.) colcemid was added ( $2 \mu \mathrm{g} / \mathrm{ml}$ Hanks' BSS $0.5 \mathrm{hr}$ ). Hypotonic treatment was done with a mixture of $6 \mathrm{ml}$ foetal calf serum (FCS, Gibco) and $24 \mathrm{ml} 0.052 \mathrm{M} \mathrm{KCl}$. Fixation was performed with acetic acid-methanol $3: 7$.

Short-term culture (Smeets et al., 1985).

The rissue specimens were collected and transported in $10 \mathrm{ml}$ RPMI 1640 medium plus $17 \% \mathrm{FCS}, 50$ ug gentamycin/ml, $50 \mathrm{U}$ penicillin/ $\mathrm{ml}$ and $50 \mathrm{U}$ streptomycin/ $\mathrm{ml}$. They were disaggregated mechanically, then incubated for 24 hrs in the medium mentioned above. Metaphase arrest with colcemid $(0.1 \mathrm{\mu g} / \mathrm{ml})$ was followed by hypotonic treatment with $0.075 \mathrm{M} \mathrm{KCl}$ and fixation in methanol-acetic acid $3: 1$. All slides were stained with Giemsa.

C-banding and $\mathrm{G}$-banding were performed (if sufficient appropriate metaplases were available) and metaphases photographed and analyzed according to the standard rules (ICSN, 1978).

Chromosomal range, modal number, distribution according to ploidy ( $\mathrm{n}=23 \pm 11$, $2 n=46 \pm 11,3 n=69 \pm 11$ etc.) and the presence of marker chromosome(s) were registered. ' Results were pooled in those cases where metaphases were obtained with the direct method as well as with the short-term culture method.

\section{Flow cytometry.}

The specimens were collected in $10 \mathrm{ml}$ RPMI 1640 medium plus $17 \% \mathrm{FCS}, 50 \mu \mathrm{g}$ gentamycin/ml, $50 \mathrm{U}$ penicillin/ $\mathrm{ml}$ and $50 \mathrm{U}$ streptomycin $/ \mathrm{ml}$. The cell suspensions were prepared mechanically as described above for the suspensions used for chromosomal analysis. The filtered cell suspensions were centrifuged at $400 \mathrm{~g}$ for $7 \mathrm{~min}$. Then, $70^{\mathrm{w}} \%$ ethanol $\left(-20^{\circ} \mathrm{C}\right)$ was added rapidly to the cell pellet with constant shaking. The final concentration was about $3 \times 10^{6}$ cells/ml ethanol. At this stage, the fixed cells could be stored for several weeks at $-20^{\circ} \mathrm{C}$. 
Immunohistochemical cell staining procedures:

Cells were incubated with a polyclonal antibody to cytokeratin (pKer; Eurodiagnostics, Apeldoorn, The Netherlands) for an indirect immunofluorescence technique (Ramaekers et al., 1983). About $1 \times 10^{6} \mathrm{cells}$ in $70 \%$ ethanol were centrifuged $(400 \mathrm{~g} ; 1.5 \mathrm{~min})$ and the pellet was resuspended with $1 \mathrm{ml}$ of $5 \% \mathrm{FCS}$ in buffer $\mathrm{A}(8.01 \mathrm{~g} \mathrm{NaCl}, 0.2 \mathrm{~g} \mathrm{KCl}, 1.44 \mathrm{~g}$ $\mathrm{Na}_{2} \mathrm{HPO}_{4}, 0.2 \mathrm{~g} \mathrm{KH}_{2} \mathrm{PO}_{4}$ in $1000 \mathrm{ml}$ water. $\left.\mathrm{pH} 7.4\right)$ and pelleted again. The cell pellet was resuspended in $0.2 \mathrm{ml}$ of the pKer antiserum, diluted 1.5 in $5 \%$ FCS in buffer $A$ and incubated for $30 \mathrm{~min}$ at room temperature with regular shaking. Then the cells were washed 3 times in $1 \mathrm{ml}$ buffer A containing $5 \% \mathrm{FCS}$. After the last washing step the cell pellet was resuspended in $0.5 \mathrm{ml}$ of FITC conjugated goat-anti-rabbit $\operatorname{lgG}$, dilluted $1: 25$ (Nordic, Tilburg, The Netherlands). After incubation for 30 minutes with this second antibody, the cells were washed again.

The cell pellet was then resuspended in $1 \mathrm{ml}$ of a propidium iodide (PI) solution ( $20 \mathrm{mg} / \mathrm{l}$ A -grade in $150 \mathrm{mM}$ sodium phosphate buffer, $\mathrm{pH} 7.4$; Calbiochem-Boehringer, La Jolla, CA). To $1 \mathrm{ml}$ of this cell suspension $0.1 \mathrm{ml}$ of a stock-solution of RNAse (1\% type $A$ in the sodium phosphate buffer; Sigma, St. Louis, $M O$ ) was added, then the cell suspension was incubated for $10 \mathrm{~min}$ at $37^{\circ} \mathrm{C}$. Finally, the cell suspension was filtered through a $100 \mu$ filter and the cells were kept in the dark at room temperature prior to FCM analysis (Ramaekers et al., 1984; Feitzet al., 1985).

\section{DNA measurements:}

Cell analysis was performed using a Cytofluorograph $5 \mathrm{OH}$ (Ortho Instruments, Westwood, MA). The fluorochromes PI and FITC were excited at $488 \mathrm{~nm}$ with an argon ion laser (Spectra Physics, Mountain View, CA). Fluorescence was measured simultaneously using a $515-530 \mathrm{~nm}$ band pass filter and a $630 \mathrm{~nm}$ long pass filter for FITC and PI, respectively. A correction was made for leakage of FITC fluorescence into the PI channel. All data were stored in list mode in a PDP 11/34 computer (Digital Equipment Corporatrom, Marboro, MA) for subsequent data andysis.

Ploidy measurements of the unlabeled tumor cells were done (Jakobsen, 1983). The DNA content was expressed as DNA index (DI) (Hiddemann et al., 1984).

The DI of the tumor cells labeled with pKer was estimated using the non-pKer-labeled cells as internal standards. The DI of normal bladder cells was 1.01 (range 0.95-1.07) with a s.d. $=0.04$.

Samples with a DI of more than 1.13 or less than $0.89(=$ mean $\pm 3 \mathrm{~s} . \mathrm{d}$. of measurements of normal bladder cells) were classified as abnormal (Smeets et al., 1987).

Percentages of cells in S- and $G_{2} M$ phases were measured (Baisch et al., 1975, 1982). The mean coefficient of variation (c.v.) for the Go/G1 peak of the tumor cells was 5.8 (range $3.5-9.3$ ).

\section{Results}

Chromosomal abnormalities were observed in 34 out of 37 cases that were analyzed successfully $(92 \%)$. Both unlabeled and labeled in 20 cases the DI was abnormal and 17 specimens showed a normal DI. In 31/37 tumors which did not contain excessive debris, the percentage of cytokeratin positive cells in $S$ - and $G_{2} M$ phase could be calculated (Fig. 1) which was not possible without pKer labeling. Among the 17 tumors with a normal DI, in one case the $S$-phase and in 2 cases the $G_{2} M$-phase were conspicuously high. Thus in 3 
of the 17 cases, formerly thought to have a normal DNA content, application of cytokeratin antibodies gave indications of abnormalities which were not seen without such labeling.

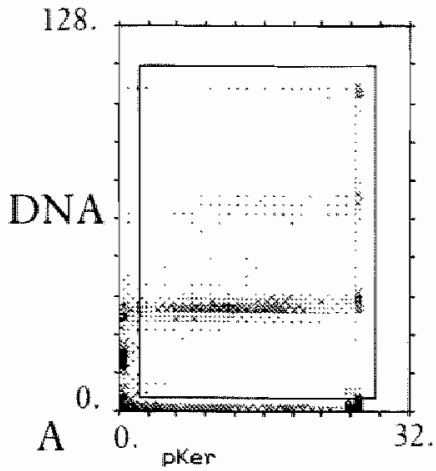

$V \mathrm{C}: 6.2 \%$

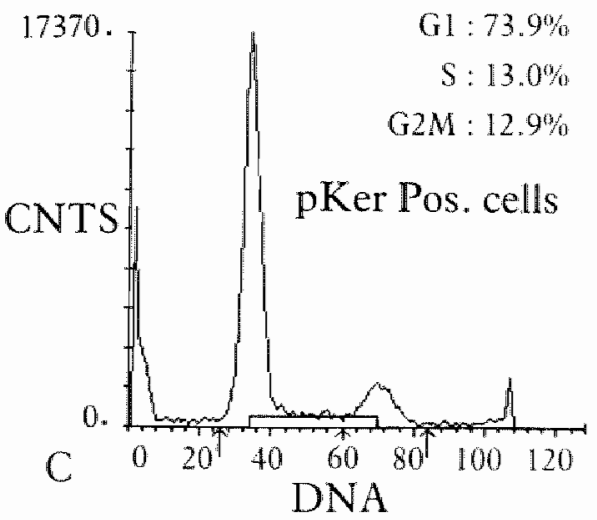

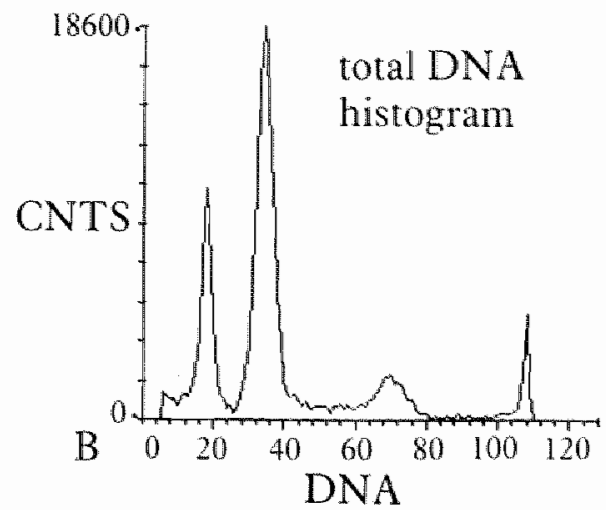

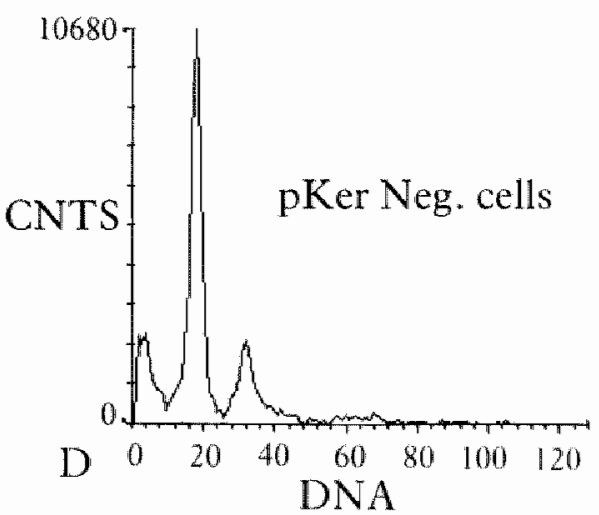

Fig. 1.

FCM analysis of a transitional bladder cell carcinoma after labeling for cytokeratin ( $\mathrm{pKer}$ ) and staining of DNA with $\mathbb{P}, \mathrm{I}$.

A. Two parameter analysis, showing position of the window containing epithelial cytokeratin positive tumor cells.

B. DNA histogram of the total cell suspension.

C. DNA histogram of the cytokeratin positive cells, selected by placing a window as illustrated in $A$.

D. DNA histogram of cytokeratin negative cells.

\section{pTa tumors}

The DI of the Go/Gl fraction in 13/14 cases of superficially growing bladder tumors was normal (2c), irrespective of the labeling for cytokeratin (Table 1). In one case (number 13) the DI was highly abnormal and after labeling a high percentage of cells was found in Sphase (mean 4.7 with a s.d. $=4.1$ ). In one diploid tumor (number 5 ) the S-phase percentage and in another case (number 9) the $\mathrm{G}_{2} \mathrm{M}$-phase percentage were very high. Without labeling the $S$-fractions of the pTa tumors were not abnormal, In 11/14 cases 
Table 1.

Results of DNA flow cytonetric and chronosomal analyses of bladder transitional cell carcinomas in relation to tumor stage.

\begin{tabular}{|c|c|c|c|c|c|c|c|c|c|c|c|}
\hline number & $T / G$ & $\mathrm{Dr}^{\mathrm{I}}$ & $\mathrm{DI}^{2}$ & $\% 5$ & $w_{6} \mathrm{G}_{2} \mathrm{M}$ & $\begin{array}{l}\text { modal } \\
\text { chrom. } \\
\text { number }\end{array}$ & range & $2 \mathrm{n}$ & $3 n$ & 4 & $\begin{array}{r}m=5 \mathrm{n} M \text { bar } \\
\text { din }\end{array}$ \\
\hline
\end{tabular}

\begin{tabular}{|c|c|c|c|c|c|c|c|c|c|c|c|c|c|}
\hline 1. & $\mathrm{TaC2}$ & 1.00 & 0.98 & 3.7 & 17.9 & 46 & $45-47$ & 10 & & & & & \\
\hline 2 & $\mathrm{TaG2}$ & 1.03 & 1.02 & 1.5 & 16.6 & 46 & $34-48$ & 30 & & & & & \\
\hline 3. & $\mathrm{TaG2}$ & 0.99 & 1.00 & 2.3 & 12.3 & 43 & $40-45$ & 40 & & & & + & t \\
\hline 4. & TaGL & 1.02 & 1.05 & 2.5 & 15.9 & 46 & $38-47$ & 20 & & & & + & +4 \\
\hline 5 & $\mathrm{TaG} 2$ & $\mathbb{\|} \| 1$ & 1.09 & 12.6 & 19.8 & 43 & $40-90$ & 19 & 1 & 5 & & + & \\
\hline 6. & $\mathrm{TaC2}$ & 1.05 & 1.13 & 4.3 & 21.4 & 46 & 46 & 6 & & & & & \\
\hline 7 & $\mathrm{TaC2}$ & 1.02 & 1.04 & 2.4 & 9.7 & 46 & 46 & 10 & & & & & \\
\hline 8 & $\mathrm{TaC}_{2}$ & 0.97 & 1.02 & 3.5 & 14.5 & 46 & 39.87 & 32 & 1 & 2 & & + & + \\
\hline 9. & $\mathrm{TaG} 2$ & 1.01 & 1.02 & 3.8 & 32.5 & 45 & $36-47$ & 15 & & & & & + \\
\hline 10 & $\mathrm{TaG} 2$ & 1.06 & 1.05 & 5.5 & 14.7 & 46 & 46 & 10 & & & & & \\
\hline 11. & $\operatorname{TaG} 2$ & 1.03 & 1.04 & 1.7 & 15.5 & 46 & $36 \times 46$ & 27 & & & & & + \\
\hline 12. & $\operatorname{TaG} 2$ & 1.00 & 1.10 & 1.5 & 6.2 & 45 & $37-46$ & 15 & & & & & + \\
\hline 13. & $\operatorname{TaG} 2$ & 1.93 & 1.91 & 15.7 & 15.5 & 78 & $40-83$ & 11 & 13 & 1 & & & \\
\hline 14. & $\operatorname{Tag} 2$ & 1.00 & 1.04 & 4.3 & 20.2 & 45 & $36 \ldots+47$ & 15 & & & & + & + \\
\hline 15. & $\mathrm{~T} 1 \mathrm{G} 2$ & 1.45 & 1.64 & 12.4 & 26.0 & 69 & $40-90$ & 1.1 & 2 & & & & + \\
\hline 16. & $\mathrm{~T} / \mathrm{G} 2$ & 2.37 & 2.23 & 8.3 & 8.7 & 87 & 6590 & & 3 & 4 & & & \\
\hline 17 & TIG2 & 1.09 & 1.06 & 7.4 & 21.9 & 44 & 37.47 & 40 & & & & & + \\
\hline 18 & $\operatorname{TIGL}$ & 1.11 & 1.02 & 2.6 & 37.9 & 46 & $42-50$ & 10 & & & & + & + \\
\hline 19 & $\mathrm{~T}: \mathrm{G} 2$ & 0.98 & 1.07 & 10.2 & 16.5 & 43 & $35-60$ & 14 & 1 & & & + & + \\
\hline 20. & $\mathrm{~T} 1 \mathrm{G} 2$ & 2.11 & 2.24 & 9.6 & 14.5 & 87 & $44-87$ & 2 & 1 & 15 & & + & + \\
\hline 21. & $\mathrm{~T} 1 \mathrm{Q} 2$ & 1.94 & 1.85 & - & - & 80 & $75-86$ & & 16 & 4 & & + & + \\
\hline 22 & $\mathrm{~T} 1 \mathrm{G} 2$ & 1.73 & 1.91 & 11.0 & 18.4 & 72 & $62-77$ & & 25 & & & + & + \\
\hline 23. & TlG3 & 1.96 & 2.00 & 16.6 & 15.1 & 73 & $44-73$ & 3 & 4 & & & + & + \\
\hline 24. & $T 1 G 2$ & 1.12 & 1.08 & 10.3 & 23.0 & $44(68)$ & $43-70$ & 28 & 6 & & & + & + \\
\hline 25. & $\mathrm{~T} 1 \mathrm{G} 2$ & 1.86 & 1.82 & 16.4 & 16.7 & 83 & $75-88$ & & I & 17 & & & + \\
\hline 26. & 1202 & 1.76 & 2.02 & 9.8 & 26.4 & $46(73)$ & $43-75$ & 27 & 6 & & & & \\
\hline 27 & $\mathrm{~T} 2 \mathrm{G3}$ & 1.69 & 1.85 & - & - & $46(70)$ & $42-70$ & 5 & 3 & & & & \\
\hline 28. & 1263 & 2.37 & 2.53 & - & . & 98 & 461110 & 3 & 1 & 15 & 1 & & + \\
\hline 29. & T2C3 & 1.68 & 1.80 & 13.3 & 18.4 & 73 & 65.73 & & 14 & & & & + \\
\hline 30. & $\mathrm{~T} 262$ & 1.95 & 1.91 & 14.2 & 13.5 & 85 & 59.93 & & 22 & 28 & & & + \\
\hline 31. & T2G3 & $\begin{array}{l}1.74 \\
(3.28)\end{array}$ & $\begin{array}{l}1.87 \\
3.60\end{array}$ & 11.0 & 11.8 & 68 & $54-117$ & 2 & 8 & & 3 & & + \\
\hline 32. & 1302 & 2.00 & 2.35 & - & - & 74 & $45-78$ & 4 & 6 & & & & + \\
\hline 33. & $\mathrm{~T} 3 \mathrm{G}$ & 1.83 & 1.79 & 16.2 & 12.1 & 77 & $46-87$ & 4 & 24 & 4 & & & + \\
\hline 34. & 1303 & 1.74 & 1.75 & 16.4 & 14.6 & 77 & $53-89$ & 1 & 28 & 2 & & & H \\
\hline 35 & $\mathrm{~T} 303$ & 1.84 & 2.04 & 11.0 & 18.4 & 73 & $62-140$ & & 38 & & 2 & + & $t$ \\
\hline 36. & $\mathrm{~T} 3 \mathrm{CB}$ & 2.83 & 2.61 & - & - & $\mathbb{1 1 . 5}$ & $73-121$ & & 3 & 2 & 35 & + & + \\
\hline 37 & $\mathrm{~T} / \mathrm{OB}$ & 1.67 & 1.77 & $\cdots$ & . & 69 & $65-125$ & & 13 & 1 & 5 & & + \\
\hline
\end{tabular}

DI' : DNA index of the Go/G1 fraction of the tumor cells, estimated without labeling with pKer.

$\mathrm{DI}^{2}$ : DNA index of the Go/Gl fraction of the tumor cells after labeling with pKer.

$M$ : Marker chromosone(s).

"\% $\mathrm{S}$ : \% cells in S-phase after labeling with $p \mathrm{Ker}$.

\% $\mathrm{G}_{2} \mathrm{M}$ : \% cells in $\mathrm{G}_{2} \mathrm{M}$ phase after labeling with pKer. 
chromosomal abnormalities were observed. With one hyperdiploid exception the modal chromosome number of these cytogenetically abnormal tumors was (hypo-)diploid, while 3 cases (numbers 5,8 and 13) showed a wide range in their chromosome number. Marker chromosomes of different types could be obtained in 7 cases. A G-banded karyotype with some abnormal chromosomes is shown in Figure 2.

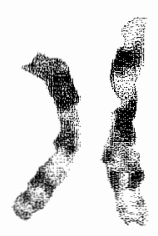

1

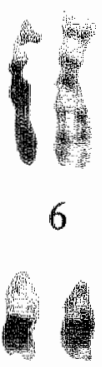

13

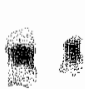

19

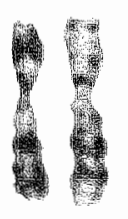

2

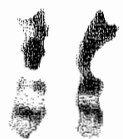

7

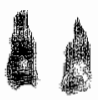

14

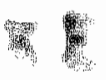

20

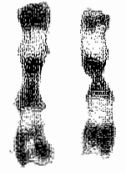

3

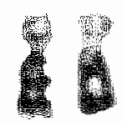

8

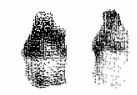

15
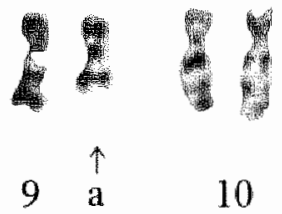

10

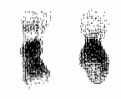

16

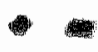

21
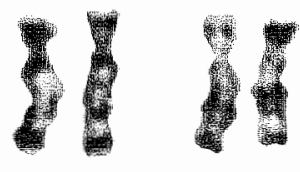

4

5

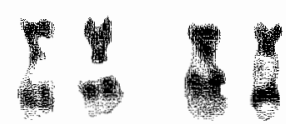

11
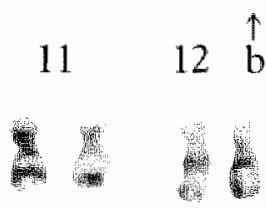

17

18

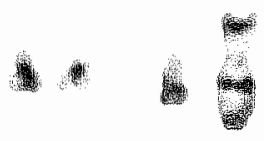

22 y $x$

Pig. 2 .

A G-banded karyotype of a Ta numor $x 4000$. Note the presence of abnomal chromosones indicated by arrows. This nmor was not found to be abnormal by FCM.

\section{pTr tumors}

The DI of the Go/Gl fraction of $7 / 11$ cases was abnormal, either with or without labeling. The mean percentage of cells in S-phase was 10.5 (s.d. $=4.1$ ). In one case with a normal $\mathrm{DI}$ (number 18) the percentage of cells in $\mathrm{G}_{2} M$ phase was extremely high.

All cases showed chromosomal abnormalities. The modal chromosome number was (hypo-)diploid in 4 cases and hyperdiploid in 7 specimens. Marker chromosomes of different types were found in $8 / 1.1$ cases.

\section{pT2-pT 4 tumors}

The DI of the Go/Gl fraction of all these cases of deeply infiltrating tumors was abnormal either with or without labeling. In one case (number 31) 2 different cell populations with an abnormal DI were found. 
The mean percentage of cells in S-phase was 13.1 (s.d. $=2.6$ ). All 12 cases showed chromosomal abnormalities. The modal chromosome number was diploid in 2 cases and hyperdiploid in 12 specimens. Marker chromosomes of different types were found in $9 / 12$ cases.

\section{Correlation between flow cytometric and chromosomal data.}

The mean value of the DNA index, as determined after labeling of pTa tumors, was $6 \%$ above the value expected from the corresponding chromosome count. For pT1 tumors this was $12 \%$ and for pT2-pT4 tumors $18 \%$ (Fig. 3).
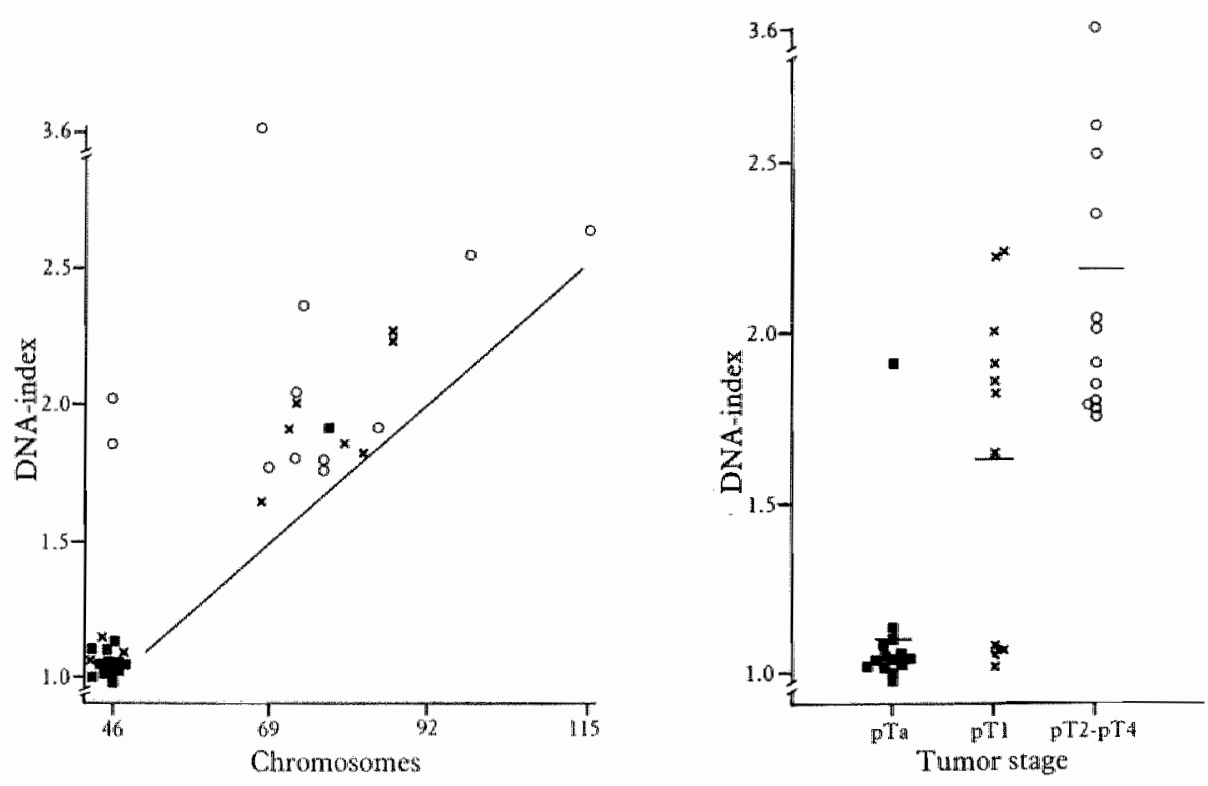

Fig. 3.

Corrdation berween the DNA index of cytokeratin positive cells and modal chromosome number.

$\square=$ p Ta tunor, $x=$ pT 1 tumor, $o=p$ T2-pT4 tumors.

Fig. $\begin{aligned} & \text { a. } \\ & \text {. }\end{aligned}$

Correlation between the DNA index of cytokeratin positive cells and tumor stage.

Mean p Ta: $1.18(\mathrm{~s} \cdot \mathrm{d} .=0.23)$ p $\mathrm{T} 1: 1.63(\mathrm{~s} \cdot \mathrm{d} .=0.45)$.

$\mathrm{pT} 2-\mathrm{pT} 4: 2.02(\mathrm{sd}=0.29)$. The horizontal bars indicate the mean values, wilcoxon test for degree of significance: pTsp T1: $\mathrm{p}=0.005$, pTa-p(T2-T4): $\mathrm{p}=0.0001$. $\mathrm{p}$ T $1-\mathrm{p}(\mathrm{T} 2-\mathrm{T} 4)$ :

$\mathrm{p}=0.069$.

\section{Correlation between DNA index, proliferative fraction and chromosomal number with tumor stage.}

The different parameters estimated from the flow cytometric studies and obtained from chromosomal analysis (Table 1) were correlated with tumor stage. It appeared that DNA 
index, S-phase and modal chromosome number showed a strong correlation with tumor invasiveness (Fig. 4-6). Strikingly, however, 2 cases of pTa tumors (cases 5 and 13) could clearly be distinguished in these comparative studies, since they showed high values for one or more parameters. Similarly, some cases of pTI tumors had values lower than average.
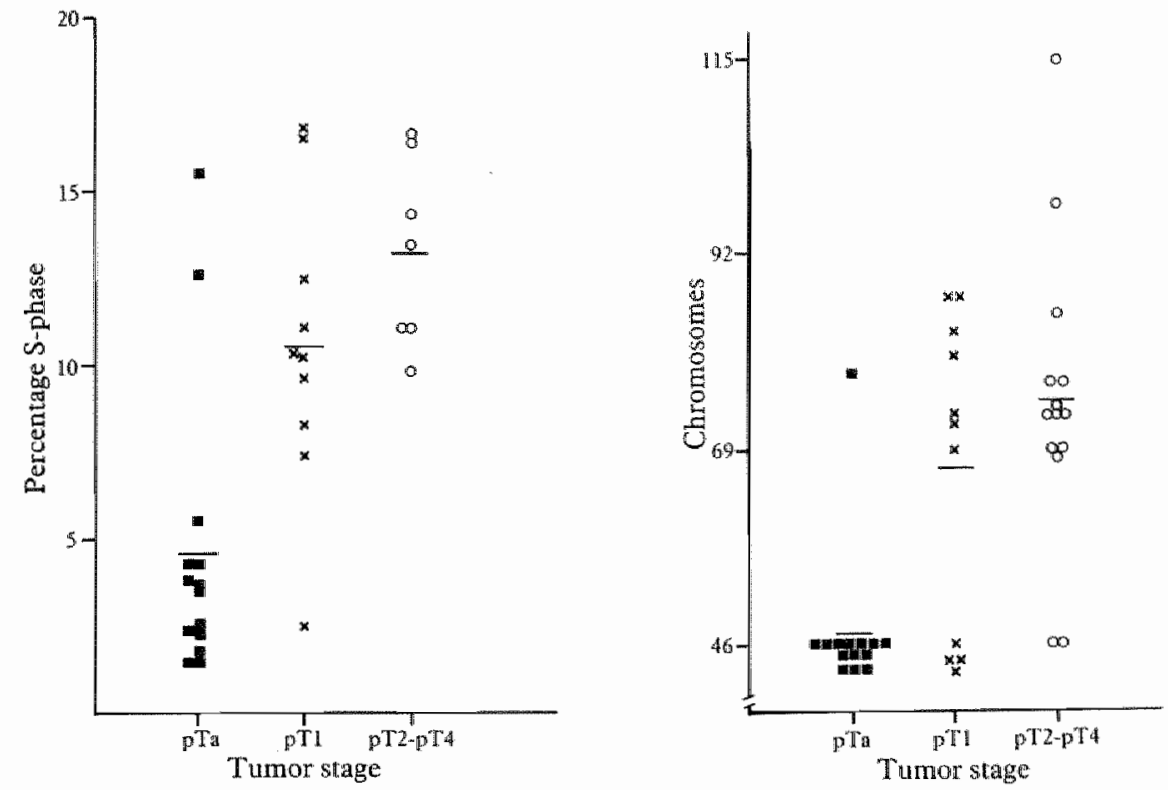

Fig. 5 .

Gorrelation between the percentage of cytokeratin positive cells in S-phase and tumor stage. Mean p Ta: 4.7 (s.d. $=4.1), \mathrm{pTl}: 10.5(\mathrm{~s}, \mathrm{~d}=4.1)$, p $2 . \mathrm{pT} 4: 13.1(\mathrm{~s}, \mathrm{~d}=2.6)$. The horizoral bars indicate the man values.

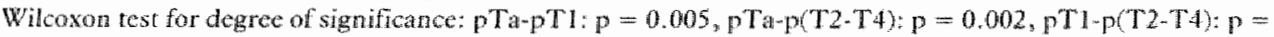
0. 170 .

Wig. 6 .

Corretation beween the rnodal chromosome number and the muor stages, The horizontal bars indicate the menn values.

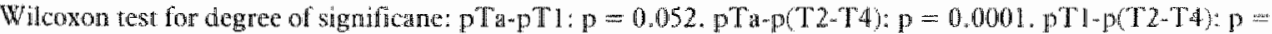
$0 .+4$.

\section{Discussion}

DNA flow cytometric (FCM) analysis of carcinoma cells has been described as a useful and reproducible method in diagnosis and management of patients with bladder tumors (Devonec et al., 1981; Wijkström et al., 1984). In order to analyse the carcinoma cells separately from contamination of non-epithelial cells, antibodies to cytokeratin can be used in a 2 parameter analysis (Ramaekers et al., 1983, 1984; Feitz et al., 1985, 1986). Although chromosomal analysis of bladder cancer is hampered by practical difficulties, essential information such as range in chromosome counts, marker chromosomes and the association of some chromosomal changes and bladder cancer can be obtained (Atkin and Baker, 1977, 1985; Gibas et al., 1984; Sandberg, 1984; Smeets et al., 1985; Vanni et al., 1985; Pauwels et al., 1987). 
In this study, the data obtained by 2 methods of DNA analysis of cells recognized with antibodies to cytokeratin and chromosomal analysis have been compared.

The advantages of using cytokeratin antiserum have been documented (Feitzet al., 1985), This study revealed 17 tumors with an apparent diploid DI. But, after labeling with the cytokeratin antiserum 3 of these cases showed strikingly high percentages of cells in $S$ - and $\mathrm{G}_{2} \mathrm{M}$ phase. This is of importance, since high $\mathrm{S}$-phase may be interpreted as an adverse prognostic factor (Barlogie et al., 1983). The high percentage of cells in $G_{2} M$ phase may possibly indicate the presence of a tetraploid cell population in the tumor. Chromosomal analysis did not show any tetraploid cells in the cases mentioned. However, there is always a risk of missing some cells by cytogenetic examination especially in specimens with low mitotic activity.

In bladder cancer cases it is of extreme prognostic and therapeutic importance to be able to distinguish between $\mathrm{p}$ Ta and $\mathrm{pT} 1$ tumors and furthermore to recognize potentially invasive $\mathrm{p} T$ a tumors. Of the 17 cases of $\mathrm{pT}$ a with a normal $\mathrm{DI}, 3$ showed indications of abnormalities when $S$-and $G_{2} M$ fractions were estimated after labeling, which thus improved the discriminatory power of FCM by $18 \%$.

The two cases of pTa tumors with a high DI and/or S-phase are particularly interesting in this respect. These tumors did also show significant chromosome abnormalities and, therefore, should be considered potentially more aggressive cases.

Chromosomal abnormalities were present in $14 / 17$ cases with a normal DI, while $11 / 17$ cases showed marker chromosomes. The 20 tumors with an abnormal DI showed, within a $10 \%$ variation the same DNA value with or without labeling for cytokeratin. All these cases showed chromosomal abnormalities. The fact that the DI is above the values expected from the corresponding chromosome count (in this study 6-18\%) has been described earlier (Granberg-Öhman et al., 1982; Wijkström et al., 1984).

Neither premature chromosome condensation (Barlogie et al., 1983) nor an increase in the number of large chromosomes, as present in many tumors (Tribukait et al., 1986), can explain this difference. Contribution of double stranded RNA is excluded since an RNAse treatment was applied before flow cytometric analysis of the cell suspensions. It is possible that a random loss of chromosomes especially in the strongly hyperdiploid tumors, may contribute to this difference.

The wide range of chromosome numbers, seen in non-infiltrating as well as in infiltrating tumors, is the result of a great heterogeneity and indicates a more aggressive behavior of the tumor (Pauwels et al., 1987). Banding of chromosomes is still problematic. C-banding could be done in most cases, but G-banding, which is necessary for karyotyping and identification of structurally abnormal chromosomes, could only be achieved in a minority of cases. Nevertheless, the presence of chromosomal abnormalities was unequivocal in most instances.

Although labeling for cytokeratin improved the value of $\mathrm{FCM}$ analysis, the discriminatory power of chromosomal analysis appeared greater than that of FCM. Near diploidy, marker chromosomes and wide range in chromosome count which is present in many superficial tumors could be not recognized by FCM in most cases.

We thus suggest a combination of chromosomal analysis and flow cytometric estimation of DI, $S$ - and $\mathrm{G}_{2} \mathrm{M}$ phase following prior labeling with antibodies to cytokeratin, when trying to recognize the potentially invasive non-infiltrating tumors. 


\section{Acknowledgements}

We thank Drs R. Schapers, R. Retera and J. Schepers (Venlo) for their cooperation. We acknowledge the technical assistance of $\mathrm{Mr}$ G. Schaart and O. Moesker in the preparation and testing of the cytokeratin antibody and the secretarial help of Miss C. Bouten. We thank the board of directors of Stichting Ziekenhuisapotheek en Klinisch Laboratorium, Psychiatric Hospital Venray and the st. Maartens Hospital Venlo for financial support.

\section{References}

Atkin, N.B., Baker, M.C., Abnomal chomosomes and number I hateroctromatin variants ucvealed in C. banded preparanions from 13 bladder carcinomas. Cycobios, 18, 101-109 (1977).

Atkin, N.B., Baker, M.C., Cyrogenecie snudy of ten carcinomas of the bladder" Involvement of chronosomes 1 and 11. Cancer Ginet. Cytogenet, 15,253-268 (1985).

Baisch, H. Gohde, W., Linden, W.A., Analysis of PCP data to determine the fraction of cells in the various phases of the cell cycle. Rad. Environ. Biophys., 12, 31-39 (1975).

Baisch, H., Otto, U., König, K., Klöppel, G., Köllermann, M, Linden, W.A., DNA content of thi human kidney carcinoma cells in relation to histological grading. Brit. I. Cancer, 45, 878-886 (1982).

Barlogie, B., Raber, M.N., Schumann, J., Johnson, T.S., Drewinko, B., Swartzendruber, D.E., Göhde, W., Andreef, M., Freireich, E.J., Flow cytometry in clinical cancer research. Cancer Res., 43, 3982-3997 (1983).

Chin, J.L., Huben, R.P., Nava, E., Rustum, Y., Greco, J.M., Pontes, J.E., Frankfurt, O.S., Flow cytomeric andysis of DNA content in human bladder tumors and irrigation fluids. Cancer, 56, 1677-1681 $(1985)$.

Collste, L.G., Darzynkiewicz, Z., Traganos, F., Sharpless, T.K., Sogani, P., Grabstald, H., Whitunore, W.F. jr., Melamed, M.R., Flow cytometry in bladder cancer detection and evaluation using acridine orange metach romatic nucleic acid staining of irrigation cytology specimens. J. Urol., 123,478-485 (1980),

Devonec, M., Darzynkiewicz, Z, Whitmore, W.F., Melamed, M.R. Flow cytometry for follow-up examinations of conservatively treated low stage bladder tumors. J. Urol., 126, 166-170 (1981).

Falor, W.H., Ward, R.M. Prognosis in tarly carcinoma of the bladder based on chromosomal analysis. Il. Urol., $119,44-48(1978)$

Feitz, W.F. J, Beck, H.L.M., Smeets, A.W.G.B., Debruyne, F.M.J., Vooijs, G.P., Hermati, C.J., Ramakers, F.C.S., Tissue - specific markers in flow cytometry of urologtcal concers: Cytokeratins in blatder carcinoma. Int. J, Cancer, 36, 349-356 (1985).

Feitz, W.F.J., Karthaus, H.F.M., Beck, H.L.M., Romijn, C., van der Meyden, A.P.M., Deburane, F.M.J, Vooijs , G.P., Ramaekers, F.C.S., Tissue-specific markes in flow cy tometry of urological cancers: II. Cytokeratin and wimentim in remal-cell tumors. Int. J. Cancer, 37, 201-207 (1986).

Frankfurt, O.S., Slocum, H.K., Rustum, Y.M., Arbuck, S.G., Pavelic, Z.P., Petrelli, N., Huben., R.P., Pontes, J.E., Greco, W.R., Flow cylometric analysis of DNA ancuploidy in primary and melastatic human solid tumors. Cytometry, $5,71 \times 80(1984)$.

Gibas, Z., Prout, G.R. jr, Connolly, J.G., Pontes, J.E., Sandberg, A.A., Nonrandon chromosomal changes in transitional cell carcinoma of the bladder. Cancer Res., 44, 1257-1264 (1984).

Granberg-Ôhman, 1., Tribukait, B., Wijkström, H., Berlin, T., Collste, L.G.,Papillary cancinoma of the urinary bladder. A study of chromosomal and cyrofuorometwic DNA analysis. Urol. Res., 8, 87.93 (1980).

Granberg-Önman, I, Tribukait, B., Wijkstrom, H., Alim, A., Berlin, T., Chromosome and DNA cytomctrí study of a papilary carcinoma of the bladder with a high stemline and numerous double minutes. Cancer Genet. Cylogener., $5,227-235(1982)$. 
Granberg-Ohman, 1., Tribukait, B., Wijkström, H., Cytogenetic analysis of 62 transitional cell bladder carcinomas Cancer Genet. Cyogenei., 11, 69-85 (1984).

Gustafson, H., Tribukait, B., Esposti, P.L., "The prognostic value of DNA analysis in primary carcinoma in situ of the urinary bladder. Scand. J. Urol. Nephrol., 16,141-146 (1982).

Harmer, M.H., (ed), TNM ditsification of malignant tumours. 3rd ed, pp. 113-117, UICC, Geneva (1978).

Hiddenaan, W., Schumann, J., Andreeff. M., Barlogie, B., Herman, C.J., Leif, R.C., Mayall, B.H., Murphy, R.F., Sandberg, A.A., Conwention on nomenclature for DNA cytometry. Cytometry, 5, 445-446 (1984).

ICSN, An International System for Human Cytogenetic Nomenclature. Cytogenet. Cell Genet., 21, 309-404 (1978).

Jakobsen, A., The usc of trout crythrocytes and human lymphocytes for standardization in flow cytometry. Cytometry, $4,161-165(1983)$.

Klein, F.A., Whitmore, W.F. jr., Herr, H.W., Melamed, M.R., Flow cytomery follow up of pathents with low stage bladder tumors. J. Urol., 128, 88-92 (1982).

Lamb, D., Correlation of chromosome counts with histological appearances and prognosis in transitional cell carcinoma of bladder". Brit. Med. J, 1, 273-277(1967).

Levi, P.E., Cooper, E.H., Anderson, C.K., Williams, R.E., Analysis of DNA content nuclear size and cell proliferation of transitional cell carcinonas in man. Cancer, 23, 1074-1085 (1969).

Pauwels, R., Smeets, W., Geraedts, J., Debruyne, $\mathbf{F}$., Cytogenetic analysis in urothelial cell carcinoma. J. Urol., 137, 210-215(1987).

Ramaekers, F.C.S., Puts J.J.G., Moesker, O., Kant, A, Huysmans, A., Haag, D., Jap, P.H.K., Herman, C.J., Vooijs, G.P., Antibodies to intermediate filamen protens in the immunohistochemical identification of human tumours: An overview. Histochem. J., 15, 691-713 (1983).

Ramaekers, F.C.S., Beck, H.L.M., Vooijs, G.P., Herman, C.J., Flow cytometric analysis of mixed cell populations using intermediate filament antibodies. Exp "Call Res., 153, 249-253 (1984).

Sandberg, A.A., The Chromosomes in Human Cancer and Leukemia. Elsevier North Wolland, New York, pp. $503-511,(1980)$.

Sandberg, A.A., Chromosomes in bladder cancer. In: American urological association. Seminar on Bladder Cancer. W.W. Bonney (ed), Monogr. 1, Bladder Cancer, pp. 81-94, Willians and Wilkins, Baltimore, (1982),

Sandberg, A.A. Chromosomal alterations associated with neoplasit. Tratrsplant. Proc. XVI, 366-369 (1984).

Smeets, W., Pauwels, R., Geraedts $\mathbf{J}$., Chromosomal analysis of bladder cancer: Technical aspects. Cancer Genet, Cytogener, $16,259-268(1985)$

Smeets, A.W.G.B., Pauwels, R.P.E., Beck, H.L.M., Feitz, W.F.J. Geraedts, J.P.M., Debruyne, F.M.J.,

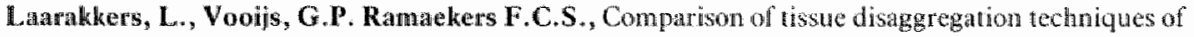
transitional cell bladder conrcinomas for flow cytometry and chromosomal analysis. Cytometry. 8, 14-19(1987).

Spooner, M.F., Cooper, E.H., Chromosone constitution of transitional cell carcinoma of the urinary bladder. Cancer, 29, 1401-1412(1972).

Summers, J.L., Falor, W.H., Ward, R., A 10-year analysis of chromosomes in non-inwasive papillary carcinoma of the bladder. J. Urol., 125, 177-178(1981).

Tribukait, B., Gustafson, H., Esposti, P.L., The significance of ploidy and proliferation in the clinical and biological evaluation of bladder rumors: A study of 100 untreated cases. Brit. J. Urol., 54, 130-135 (1982).

Tribukait, B., Granberg-Öhnan, I., Wijkström, H., Flow cytometric DNA and cytogenetic studies in human tumors: A comparison and discussion of the differences in modal values obtained by the two methods. Cytometry, 7, 194-199(1986).

Vanni, R., Peretti, D., Scarpa, R.M., Usai, E., Deriwative 11 marker chromosome in bladder carcinoma. Cancer Genet. Cytogenet., 16, 289-295(1985). 
Wijkström, H., Granberg-Öhman, I., Tribukait, B., Chromosomal and DNA patterns in transitional cell bladder carcinoma. A comparative cytogenetic and flow cytofuorometric DNA study. Cancer, 53, 1718-1723 (1984).

World Health Organization, Hisnological typing of urinary bladder tumours. In: International Histological Classification of Tumors, no. 10, WHO, Geneva (1973). 



\section{Chapter V}

\section{Grading in superficial bladder cancer.}

\section{Cytogenetic classification.}

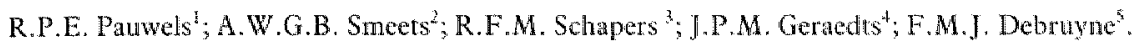

${ }^{1}$ Department of Urology, St. Maartens Gasthuis, Venlo.

${ }^{2}$ Stichting Ziekenhuisapotheek en Klinisch Laboratorium Venray.

${ }^{3}$ Department of Pathology, St. Maartens Gasthuis, Venlo.

${ }^{4}$ Department of Genetics and Cell Biology, State University Limburg.

${ }_{5}^{5}$ Department of Urology, Radboud Hospital of the Caholic University Nijmegen. 


\section{Summary}

Cytogenetic analysis was performed in 92 newly diagnosed transitional cell bladder carcinomas. The results of this analysis were correlated with the clinical course in the superficial tumors. Low grade tumors appeared to have hypo- or peri-diploid chromosomal numbers. Intermediate grade tumors were characterized by chromosomal counts up to the hyperdiploid range, but could have a peri-diploid modal number. With respect to the clinical course of superficial tumors the range in chromosomal counts appeared to be more reliable than the modal number. The significant difference in chromosome numbers between low, intermediate and high grade tumors may be considered as a biollogical basis for grading.

\section{Introduction}

The natural history of a papillary tumor of the bladder is unpredictable. Next to tumor stage, grade is at present the most important indicator of the clinical behavior of a bladder tumor (Kern, 1984). However, reports regarding grade are not always completely comparable because different grading systems are used, or different interpretations are given to one grading system (Hofstädter et al., 1984). Chromosomal analysis is mentioned as one of the more objective criteria of the malignant potential of bladder cancer (Lamb, 1967; Spooner and Cooper, 1972).

Cytogenetic studies showed a positive correlation between histological grade and modal chromosome numbers for low and high grade bladder tumors (Spooner and Cooper, 1972; Wijkström et al., 1984). In intermediate grade tumors normal as well as abnormal modal numbers were found. In another study (Pauwels et al., 1987) an interpretation of the W.H.O. grading criteria was established which appeared to correlate with rate of recurrences and tumor progression.

The aim of this study was to investigate whether this interpretation of the W.H.O.grading classification could be confirmed by a cytogenetic study.

\section{Patients and methods}

Between 1980 and 1986, from 92 patients with a primary transitional cell carcinoma of the bladder only treated by TUR, chromosomal data from tumor specimens were achieved (see table 1).

Table 1 .

Number of patients in relation to tumor stage and grade.

\begin{tabular}{lrrrr} 
Grade & \multicolumn{3}{c}{ Tumor stage } & Totals \\
\hline $\mathrm{G} 1$ & $\mathrm{Ta}$ & $\mathrm{T}$ & $\mathrm{T} 2-4$ & \\
$\mathrm{G} 2$ & 31 & 1 & - & 32 \\
$\mathrm{G} 3$ & 9 & 15 & 11 & 35 \\
Total & - & 5 & 20 & 25 \\
\hline
\end{tabular}

Staging was done according to the T.N.M.-system (Harmer, 1978). As grade 1 were classified tumors showing increased cellularity with or without slight nuclear and cellular variations but with normal polarity of individual cells. Tumors showing clear cytological 
deviations with a tendency to loose normal polarity were classified grade 2 . Tumors were called grade 3 if considerable cellular deviation was seen, with strong variations in size and shape of cells and nuclei and a loss of normal cellular architecture.

Patients with a superficial (Ta-Tl) low or intermediate grade tumor were followed by cystoscopy for 3 to 62 - mean 28 - months. If chemotherapy, immunotherapy or radical therapy was applied, or tumor progression occurred, follow-up ended.

\section{Cytogenetic analysis.}

For microscopic analysis of chromosomes, cells in metaphase were obtained from a suspension of single cells. After colcemid arrest, hypotonic treatment and fixation, the chromosomes were routinely stained with Giemsa. For further identification of chromosomes, specific banding techniques are available. The techniques used for cytogenetic analysis -direct method or short term culture - have been described previously (Smeets et al., 1985).

Analysable metaphases, at least 5 (average 28) per case were photographed and karyotyped according to the Paris nomenclature (I.S.C.N., 1978). The tumors were classified according to the modal chromosome number and chromosome range. The latter classification distinguished the tumors with cells only in the hypo-diploid or peri-diploid range ( 49 or less) and cells with more than 49 chromosomes (hyperdiploid).

Marker chromosomes, structurally abnormal chromosomes, as mentioned in this study were shown by routine techniques, mostly in non-banded preparations.

\section{Results}

\section{Normal bladder tissue.}

In 15 patients with non-infiltrating tumors, random biopsies from cystoscopically normal bladder tissue showed neither histopathological nor cytogenetic abnormalities.

\section{Tumor stage and grade.}

The majority of non-invasive tumors (Ta) had peri-diploid chromosomal numbers ( $\mathrm{sec}$ table 2).

Table 2.

Tumor stage in relation to chromosomal numbers.

\begin{tabular}{|c|c|c|c|}
\hline \multirow[t]{2}{*}{ chromosonal number } & \multicolumn{3}{|c|}{ Number and stage of tumors } \\
\hline & $\mathrm{Ta}$ & T1 & $\mathrm{T} 2-4$ \\
\hline modal number $\leqslant 49$ & 35 & 9 & 6 \\
\hline modal number $>49$ & 5 & 12 & 25 \\
\hline range & 31 & - & - \\
\hline range & 9 & 21 & 31 \\
\hline
\end{tabular}

In all infiltrating tumors, cells with more than 49 chromosomes were present, although the modal number often was peri-diploid. The difference in the range of chromosomal numbers between non-invasive and invasive tumors is significant $(p<0.001)$. As is shown in table 3 all except one grade 1 tumors had a modal number of 49 or less. In nearly half of the 35 grade 2 tumors the modal number was peri-diploid. Nearly always, however, cells in the hyperdiploid range were seen like in all grade 3 tumors. The 
differences in chromosomal numbers (mode and range) between grade 1 and grade 2 tumors are significant $(p<0.001)$. Between grade 2 and grade 3 tumors there was a significant difference in modal number $(p<0.002)$.

Table 3.

Tumot grade in relation to chromosomal numbers.

\begin{tabular}{|c|c|c|c|}
\hline \multirow[t]{2}{*}{ chromosomal number } & \multicolumn{3}{|c|}{ Nunber and grade of umons } \\
\hline & $\mathrm{Gl}$ & $\mathrm{G} 2$ & $\mathrm{G} 3$ \\
\hline nodal number $\leqslant 49$ & 31 & 17 & 2 \\
\hline modal number $>49$ & 1 & 18 & 23 \\
\hline range & 28 & 3 & - \\
\hline range & 4 & 32 & 25 \\
\hline
\end{tabular}

Marker chromosomes were found in 17 of the 40 non-invasive tumors $(43 \%)$ and in 31 of the 52 invasive cases $(60 \%)(\mathrm{p}=0.22)$. Nine out of 32 grade 1 tumors showed markers $(28 \%)$ compared with 39 of the 60 grade 2 and grade 3 cases $(65 \%)$. So, in higher grade tumors more often marker chromosomes were found $(\mathrm{p}=0.003)$.

\section{Follow up of superficial low and intermediate grade tumors.}

Fourty-two patients with a superficial low or intermediate grade tumor were evaluable for follow up (see table 4).

Table 4.

Correlation of results of chromosomal analysis with clinical course for superficial (Ta - Tr) low and intermedilate grade bladder tumors.

\begin{tabular}{|c|c|c|c|c|c|c|}
\hline \multirow{3}{*}{ patients } & \multicolumn{6}{|c|}{ Resulls of chromosomal analysis. } \\
\hline & \multicolumn{2}{|c|}{ modid number } & \multicolumn{2}{|c|}{ Dhromosomal range } & \multicolumn{2}{|c|}{ Inarker chromosomes } \\
\hline & $\leqslant 49$ & $>49$ & $\leqslant 49$ & $>49$ & no & yes \\
\hline cvaluabla & 37 & 5 & 28 & 14 & 24 & 18 \\
\hline digewse lree & $19(51 \%)$ & $0^{\mathrm{i}}$ & $16(57 \%)$ & $3(21 \%)^{\mathrm{h}}$ & $13(54 \%)$ & $6(33 \%)$ \\
\hline $\begin{array}{l}\text { with tumor } \\
\text { progression }\end{array}$ & $7(19 \%)$ & $2(401 / 4)^{d}$ & $3(11 \%)$ & $6(43 \%)$ & $4(17 \%)$ & $5(280 \%)^{1}$ \\
\hline reculariac rate & 3.0 & 2.7 & 2.9 & 3.0 & 2.2 & 3.9 \\
\hline
\end{tabular}

Follow up 3 to 62 - mean 28 - months.

Recurrence rate: $n$ recurrences/n months patient follow up 100 " $\mathrm{p}=0.07 ; \mathrm{p}=0.16 ;{ }^{\mathrm{c}} \mathrm{p}=0.50 ; \mathrm{p}=0.62$; ${ }^{\mathrm{c}} \mathrm{p}=0.05 ; \mathrm{p}=0.63$

Fifty-one percent of the tumors with a peri-diploid modal number did not recur. In the group with hyperdiploid modal numbers all tumors recurred $(p=0.07)$. With respect to tumor progression no significant difference was seen between these two groups $(p=0.62)$. If, however, in a tumor chromosomal numbers in the hyperdiploid range were shown, tumor progression was seen significantly more often than in the group with lower chromosomal numbers ( $\mathrm{p}=0.05$ ).

The tumor recurrence rates showed no significant differences between the groups. However, estimations using the Kaplan-Meier method show that in the group with a hypo- or peri-diploid chromosomal range the first 18 months only $10 \%$ had a recurrence, 
which figure rose to $69 \%$ after 42 months. In the group with a hyperdiploid chromosomal range, $54 \%$ had at least one recurrence after 18 months. So, tumors with a hypo- or peridiploid chromosomal range clearly recurred much later.

In four cases progression was seen in tumors with near normal modal numbers but a hyperdiploid chromosomal range. With respect to the clinical course, no sifnificant difference between the groups with or without marker chromosomes was observed. An addendum shows the histopathological and cytogenetic data, and follow up of the clinical course for each patient.

\section{Discussion}

In a previous study about grading in superficial bladder cancer, a clear correlation between morphological criteria and the clinical course of bladder tumors was found (Pauwels et al., 1.987). The present study was done to see whether a correlation between chromosomal abnormalities and the grading criteria used could be demonstrated.

Grade 1 tumors appeared to have hypo- or peri-diploid chromosomal numbers. Grade 2 tumors show in half of the cases a peri-diploid modal number but nearly always they contain a number of cells with more than 49 chromosomes. In grade 3 tumors the chromosomal mode is strongly hyperdiploid. Other authors also reported that grade 2 tumors are heterogeneous with respect to modal number (Spooner and Cooper, 1972; Wijkström et al., 1984). The significant difference in chromosomal range between grade 1 and grade 2 tumors is not reported before.

Tumors graded by us as intermediate recur significantly earlier, and progress more often than low grade tumors (Pauwels et al., 1987). These grade 2 tumors appear to have chromosomal numbers up to the hyperdiploid range. This means that nuclear pleomorphism, enlargement and hyperchromasia probably reflect the increase in chromosome number and the increased aggressiveness of a tumor.

Tumors having a peri-diploid modal number but a range till in the hyperdiploid region, tended to behave worse than tumors with only near normal chromosomal numbers. The finding of hyperdiploid modal numbers in intermediate grade superficial bladder tumors, like by FCM analysis higher DNA values, is a bad prognostic sign (Wijkström et all, 1984). However, a near normal modal chromosomal number does not always indicate a benign behavior of the tumor.

Marker chromosomes in superficial bladder cancers were regarded as a very bad prognostic factor (Falor and Ward, 1978; Summers et al., 1981). In our study this could not be confirmed. For establishing structural abnormalities so called chromosome banding techniques are necessary.

By the use of different banding techniques non-random chromosomal changes have been demonstrated in bladder tumors (Gibas et al., 1984; Atkin and Baker, 1985). The prognostic significance of the different changes are not yet known. The increasing variation in chromosomal number during the progression of the neoplasia is believed to confer proliferative advantage to the tumor cells (Yunis, 1983).

Our grading criteria in superficial bladder cancer were proved to have a clinical basis with respect to tumor stage, rare of recurrences and tumor progression (Pauwels et al., 1987). The conclusion of this study may be that with chromosomal analysis we were able to give a biological meaning to our grading system. 


\section{Acknowledgements}

The authors wish to thank Drs J. Scheepers, urologist, and Drs R. Retera, pathologist, for their cooperation; Drs W. Doesburg and A. Reintjes, Mathematical Statistical Department, University of Nijmegen, for statistical evaluation; the Operating Room personnel for their willing compliance with this study; Miss L. Laarakkers and Miss W. Janssen for technical assistance; Miss $M$. Maas for typing the manuscript, and the board of directors of the Stichting Ziekenhuisapotheek en Klinisch Laboratorium Venray and of the Psychiatric Hospital Venray, for financial support.

\section{Addendum:}

Historathologic and cylogeneic data for the inital bopsy from individual bladder carcinoma patients with bollow ung.

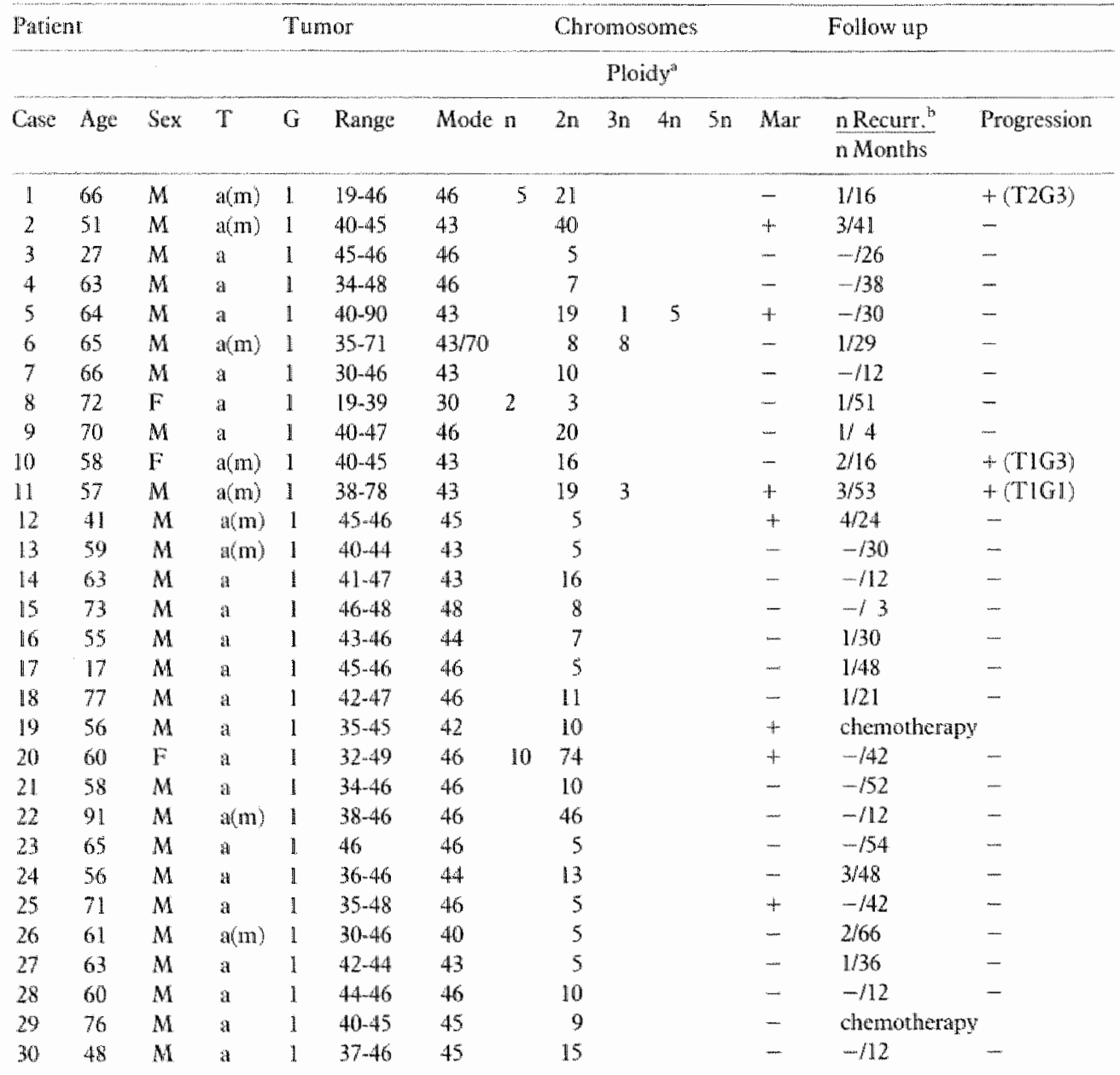




\begin{tabular}{|c|c|c|c|c|c|c|c|c|c|c|c|c|c|c|}
\hline \multicolumn{4}{|c|}{ Patient } & \multicolumn{4}{|c|}{ Tumor } & \multicolumn{5}{|c|}{ Chromosomes } & \multicolumn{2}{|l|}{ Follow up } \\
\hline & & & \multicolumn{12}{|c|}{$\mathbb{P l o i d y}^{\text {th }}$} \\
\hline Case & Age & Sex & $T$ & $G$ & Range & Mode & $\mathrm{n}$ & $2 n$ & $3 n$ & $4 n$ & $5 n$ & Mar & $\frac{\text { a Recurr." }}{\text { n Monihs }}$ & Progression \\
\hline 31 & 66 & $\mathrm{M}$ & $a$ & $\mathbb{1}$ & $36-47$ & 45 & & 16 & & & & + & -115 & - \\
\hline 32 & 65 & $\mathrm{M}$ & $\mathrm{a}$ & 2 & 19.45 & 42 & $\llbracket 1$ & 16 & & & & + & $4 / 24$ & $+\left(\mathrm{T}_{102}\right)$ \\
\hline 33 & 73 & $M$ & $a$ & 2 & $60-89$ & 70 & & & 7 & & & + & $1 / 28$ & $+(\mathrm{T} 2 \mathrm{G} 3)$ \\
\hline 34 & 82 & $\mathrm{M}$ & $a$ & 2 & 50.90 & 67 & & 2 & 7 & 4 & & + & not fit for treat & tment \\
\hline 35 & 61 & M & $\mathrm{a}$ & 2 & 50.75 & 64 & & & 20 & & & + & $1 / 60$ & - \\
\hline 36 & 72 & $\mathrm{~F}$ & $a$ & 2 & $38-57$ & 45 & & 11 & & & & \pm & -118 & - \\
\hline 37 & 66 & $\mathrm{M}$ & a & 2 & $23-44$ & 40 & 4 & 31 & & & & + & $1 / 26$ & - \\
\hline 38 & 78 & $\mathrm{M}$ & a & 2 & 39.87 & 45 & & 31 & 1 & 2 & & + & $1 / 25$ & - \\
\hline 39 & 44 & M & $\mathbf{a}$ & 2 & $36-49$ & 46 & & 27 & & & & t & chennotherapy & \\
\hline 40 & 83 & $M$ & $a$ & 2 & $40-83$ & 78 & & 13 & 13 & l & & + & chemothearpy & \\
\hline 41 & 55 & $M$ & 1 & $\mathbb{1}$ & 37.72 & 44 & & 47 & 1 & & & + & $1 / 20$ & - \\
\hline 42 & 78 & $\mathrm{~F}$ & $1(\mathrm{~m})$ & 2 & $46-92$ & 46 & & 38 & 6 & 4 & & - & $1 / 5$ & $+(\mathrm{T} 2(\mathrm{~m}) \mathrm{G})$ \\
\hline 43 & 66 & $M$ & $1(\mathrm{~m})$ & 2 & $35-72$ & 65 & & 4 & 7 & & & + & $1 / 4$ & $+(\mathrm{T} 2 \mathrm{~m}) \mathrm{G} 3)$ \\
\hline 44 & 77 & $M$ & 1 & 2 & 28.73 & 53 & 2 & 9 & 5 & & & + & $1 / 62$ & - \\
\hline 45 & 86 & $\mathrm{M}$ & 1 & 2 & $46-120$ & 70 & & 14 & 53 & 2 & & + & death umelate & d to cances: \\
\hline 46 & 59 & $M$ & 1 & 2 & $35-72$ & 42 & & 38 & 2 & & & + & -140 & $-\ldots$ \\
\hline 47 & 72 & $\mathrm{M}$ & 1 & 2 & $62-77$ & 72 & & & 25 & & & + & chemotherapy & \\
\hline 48 & 53 & $\mathrm{M}$ & 1 & 2 & $35-57$ & 43 & & 13 & & & & + & radiotherapy & \\
\hline 49 & 54 & $M$ & 1 & 2 & $19-69$ & 44 & 11 & 38 & 6 & & & + & dean umrelate & ed to cancer \\
\hline 50 & 62 & $\mathrm{~F}$ & 1 & 2 & 44.89 & 87 & & 2 & 1 & 16 & & + & chentotherapy & \\
\hline 51 & 86 & $\mathrm{~F}$ & 1 & 2 & $75-86$ & 80 & & & 16 & 4 & & + & chenotherapy & \\
\hline 52 & 70 & F & 1 & 2 & $43-70$ & 44 & & 18 & 6 & & & + & chemotherapy & \\
\hline 53 & 74 & $M$ & 1 & 2 & $44-86$ & 47 & & 21 & & 1 & & - & chemotherapy & \\
\hline 54 & 81 & $M$ & 1 & 2 & $75-88$ & 84 & & & & 18 & & - & chenotherapy & \\
\hline 55 & 69 & $\mathrm{~F}$ & $1(\mathrm{~m})$ & 2 & $23-80$ & 45 & 4 & 7 & 4 & & & - & $1 / 4$ & $+(\mathrm{T} 3 \mathrm{G} 3)$ \\
\hline 56 & 69 & $\mathrm{M}$ & 1 & 2 & $30-87$ & 46 & & 32 & 1. & 2 & & + & $1 / 8$ & $+(\mathrm{T} 2 \mathrm{G} 3 \mathrm{ML})$ \\
\hline 57 & 73 & $\mathrm{~F}$ & 1 & 3 & $70-89$ & 73 & & & 3 & 3 & & + & radiotherapy & \\
\hline 58 & 68 & $M$ & 1 & 3 & $86-100$ & 90 & & & 5 & & & - & radiotherapy & \\
\hline 59 & 45 & $M$ & 1 & 3 & 6590 & 70 & & & 5 & 2 & & - & -19 & - \\
\hline 60 & 60 & $M$ & 1 & 3 & $43-100$ & 88 & & 1 & 1 & 13 & & $\ldots$ & $1 / 3$ & $\ldots$ \\
\hline 61 & 65 & $M$ & 1 & 3 & $43-147$ & 146 & & 1 & 1 & 1 & 4 & + & $1 / 5$ & - \\
\hline 62 & 73 & $M$ & 2 & 2 & $43-75$ & 46 & & 27 & 6 & & & - & -124 & - \\
\hline 63 & 75 & $M$ & $2(\mathrm{~m})$ & 2 & $59 \times 93$ & 85 & & & 22 & 28 & & + & cystectomy & \\
\hline 64 & 84 & $M$ & 2 & 2 & $30-89$ & 72 & 1 & 2 & 1.5 & 2 & & + & radiothorapy & tweytcclomy \\
\hline 65 & 54 & $M$ & 2 & 3 & $65-73$ & 72 & & & 6 & 8 & & + & radiotherapy & + cystecom \\
\hline 66 & 70 & $M$ & 2 & 3 & $53-76$ & 73 & & 2 & 23 & & & + & radiotherapy & + cystectom \\
\hline 67 & 74 & $\mathrm{~F}$ & 2 & 3 & $46-110$ & 98 & & 3 & 1 & 16 & 1 & $\ldots$ & deatle urirelato & ed lo cancer \\
\hline 68 & 82 & $M$ & 2 & 3 & $19-93$ & 58 & 3 & 3 & 3 & & & + & radiotherapy & + cystectomy \\
\hline 69 & 53 & $M$ & 2 & 3 & $54-117$ & 60 & & 2 & 8 & & 3 & + & cystectomy & \\
\hline 70 & 71 & $\mathrm{~F}$ & 2 & 3 & $42-70$ & 44 & & 5 & 1 & & & - & radiothoratpy & + cysncelom \\
\hline 71 & 87 & $F$ & 2 & 3 & $50-220$ & 110 & & & & 15 & 10 & + & radiothe rapy & \\
\hline 72 & 56 & $\mathrm{M}$ & 2 & 3 & $46-90$ & $46 / 90$ & & 3 & 1 & 4 & & - & radictherapy & + cystectomy \\
\hline 73 & 70 & $\mathrm{~F}$ & $2(\mathrm{~m})$ & 3 & $36-90$ & 69 & & 17 & 2 & 10 & & 4 & radiotherapy & \\
\hline 74 & 76 & $M$ & 2 & 3 & $30-69$ & $45 / 90$ & & 20 & - & 24 & & - & death un relate & ed to cancer \\
\hline 75 & 67 & $\mathrm{~F}$ & 3 & 2 & $53-81$ & 77 & & 2 & 28 & 1 & & H & cystitoctony & \\
\hline 76 & 66 & $M$ & 3 & 2 & $46-100$ & 69 & & 1 & 3 & 1 & & - & radionerapy & \\
\hline 77 & 72 & $M$ & $3(\mathrm{~m})$ & 2 & $40-69$ & 46 & & 4 & 2 & & & $t$ & cystectomy & \\
\hline 78 & 78 & $M$ & 3 & 2 & $65-80$ & 73 & & & 13 & & & H & radiontherapy & \\
\hline 79 & 73 & $M$ & 3 & 2 & $42-62$ & 46 & & 9 & 1 & & & - & radiotherapy & \\
\hline 80 & 80 & $M$ & 3 & 2 & $40-90$ & $46 \%$ & & 10 & & 10 & & - & death unrelate & ed to cancerr \\
\hline
\end{tabular}




\begin{tabular}{|c|c|c|c|c|c|c|c|c|c|c|c|c|c|c|}
\hline \multicolumn{4}{|c|}{ Patient } & \multicolumn{4}{|c|}{ Turnor } & \multicolumn{5}{|c|}{ Chromosomes } & \multicolumn{2}{|l|}{ Follow up } \\
\hline & & & \multicolumn{12}{|c|}{ Ploidy } \\
\hline Case & Age & $\operatorname{sex}$ & $\mathrm{T}$ & $G$ & Range & Modle on & & $2 n$ & $3 n$ & $4 n$ & $5 \mathrm{n}$ & Mar & $\frac{\text { nRecurr." }}{\text { n Months }}$ & Progression \\
\hline 81 & 69 & $M$ & 3 & 2 & $46-90$ & 46 & & 6 & & 2 & & - & cystectomy & \\
\hline 82 & 64 & $M$ & 3 & 3 & $45-75$ & 75 & & 4 & 6 & & & + & cystectomy & \\
\hline 83 & 74 & $M$ & $3(m)$ & 3 & $62-140$ & 73 & & & 37 & & 2 & + & radiotherapy & \\
\hline 84 & 75 & $M$ & 3 & 3 & 90.95 & 92 & & & & 5 & & + & radiotherapy & \\
\hline 85 & 73 & $M$ & 3 & 3 & $42-90$ & 45 & & 3 & 2 & & & - & cystectony & \\
\hline 86 & 56 & $\mathrm{M}$ & $3(\mathrm{~m})$ & 3 & $64-90$ & 75 & & & 5 & 5 & & + & ractiotherapy & \\
\hline 87 & 74 & $\mathrm{~F}$ & 3 & 3 & $50-90$ & 70 & & & 4 & $\mathbb{1}$ & & 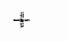 & radiotherapy & \\
\hline 88 & 64 & $M$ & 3 & 3 & $19-69$ & 50 & 1 & 4 & 4 & 13 & & - & death of cancer & \\
\hline 89 & 70 & $M$ & $3(\mathrm{~m})$ & 3 & $73-121$ & 115 & & & 3 & 2 & 35 & + & radiotherapy & \\
\hline 90 & 60 & $M$ & $4(\mathrm{~m})$ & 2 & $40-140$ & 43 & & 19 & 4 & 1 & 5 & $-\cdots$ & radiotherapy & \\
\hline 91 & 66 & $\mathrm{M}$ & 4 & 3 & $65-135$ & 69 & & & 13 & 1 & 6 & - & death of cancer & \\
\hline 92 & 44 & $\mathrm{~F}$ & 4 & 3 & $46-120$ & 56 & & 8 & 3 & 1 & & - & radiotherapy & \\
\hline
\end{tabular}

"Ploidy: $n=23 \pm 11 ; 2 n=46 \pm 11 ; 3 n=69 \pm 11$ elc.

${ }^{\text {b }} \mathrm{n}$ Recurr. " number of recurrences per total number months of follow up. n Months

\section{References}

Atkin, N.B., Baker, M.C. (1985). Cytogenetic study of carcinomas of the bladder: involvement of chromosomes 1 and 11 . Cancer Genetics and Cytogenetics, 15, 253-257.

Falor, W.H., Ward, R.M. (1978). Prognosis in early carcinoma of the bladder based on chromosomal analysis. The Journal of Urology, 119, 44-48.

Gibas, Z., Prout jr., G.R., Conolly, J.C., Pontes, J.E., Sandberg, A. A. (1984). Nonrandom chromosomal changes in transitional cell carcinoma of the bladder. Cancer Research, 44, 1257-1264.

Harmer, M.H., editor. (1978). T.N.M.-classification of malignant rumours. Third edition, U.I.C.C., Geneva.

Holstädter, F, Jakse, G., Lederer, B., Mikux, . G., Delgado, R. (1984). Biological behaviour and DNA cytophotometry of urotheliat bladder carcinoma. British Journal of Urology $56,289-295$.

1.S.C.N. (1978). An international system for human cytogenetic nomenclature. Birth defects: Original Article Series, Vol. XIV, no. 8. The National Foundation, New-York.

Kern, W.H. (1984). The grade and pathologic stage of bladder cancer. Cancer, 53, 1185-1189.

Lamb, D. (1967). Correlation of chromosome counts with histological appearances and prognosis in transirional cell carcinoma of bladder. British Medical Journal, 1, 273-277.

Pauwels, R.P.E., Schapers, R.F.M., Smeets, A.W.G.B., Geraedts, J.P.M., Debruyne, F.M.J. (I987). Grading in superficial bladder cancer. 1. Morphological criteria. British Journal of Urology. In press.

Smeets, W., Pauwels, R., Geraedts, J. ( 1985 ). Chromosomal analysis of bladder cancer: technical aspects. Cancer Genetics and Cytogenetics, 16, 259-268.

Spooner, M.E., Cooper, E.H. (1972). Chromosome constitution of transitional cell carcinoma of the urinary bladder. Cancel, 29, 1401-1412.

Summers, J.L., Fallor, W.H., Ward, R.M. (1981). A 10- year analysis of chromosomes in non-invasive papillary carcinoma of the bladder. "The Journal of Urology, $125,177-178$.

Wijkström, H., Granberg-Öman, I., Tribukain B. (1984). Chromosomal and DNA patterns in transitional cell bladder carcinoma. A comparitive gytogenetic and flowcytofuorometric DNA study. Cancer, 53, 1718-1723.

Yunis, J.J. (1983). The chromosomal basis of human neoplasia. Science, 221, 227-236. 


\section{Chapter VI}

\section{Chromosomal analysis of bladder cancer. II.}

\section{A practical method.}

Wim Smeets ${ }^{1}$, Ruud $\mathbb{P}_{\text {auwels }}{ }^{2}$, Lisette Laarakkers', Frans Debruyne ${ }^{3}$ and foep Geraedts".

'Stichting Ziekenhuisapotheek en Klinisch Laboratorium Venray.

${ }^{2}$ Department of Urology of st. Maartens Hospital, Venlo.

${ }^{3}$ Department of Urology, Radboud Hospital of the Catholic University Nijmegen.

${ }^{4}$ Department of Genetics and Cell Biology of the State University Limburg. 


\section{Abstract}

Twenty-seven successive bladder cancer tissue specimens varying from non-infiltrating to deeply infiltrating ones, were chromosomally analyzed using a new direct method. Recognizable metaphases were obtained in twenty-five specimens $(93 \%)$. In nearly all cases suitable C-banding, and in nine cases G-banding was achieved.

Essential steps in this method are colcemid application in two steps, interrupted by washing with Hanks BSS and two separated hypotonic treatments.

This method is easy to use and not time expensive.

\section{Introduction}

Chromosome analysis of bladder cancer is often hampered by several of the following factors: small number of recognizable metaphases, lack of spreading and condensed or fuzzy nature of the chromosomes. Successful chromosome analysis, using a direct technique combined with conventional staining appeared possible in about $50 \%$ of the tumor specimens [1-3].

This percentage decreased when banding was applied [4,5]. As pointed out in the past, most of the tumor specimens contained metaphases but they could not be analyzed due to the poor morphology. Hence, technical improvements are necessary to obtain recognizable metaphases [2]. Several laboratories introduced methodologic improvements, especially with regard to tumor disaggregation and in vitro culture [6]. In this study a simple direct technique is described which can give recognizable metaphases in nearly all stages and grades of bladder tumors.

\section{Materials and methods}

Twenty-seven tissue specimens were obtained by transurethral resection (TURT) or by cold-cup biopsy from 26 successive patients, 25 with primary and one with recurrent tumors. None of these patients had previously been treated with radiation or intravesical chemotherapy. The specimens came from the urological department of one clinic and were taken by two urologists with many years of experience. The tumors varied from noninfiltrating to deeply infiltrating ones (Ta-T3).

The specimens were cut in two parts in the operating room. One part was put in $10 \mathrm{ml}$ $0.5 \%$ sodium citrate $+0.5 \mu \mathrm{g} / \mathrm{ml}$ colcemid (Gibco) and the other in $10 \mathrm{ml}$ of Earl's solution (room temperature). The specimens arrived at the cytogenetic laboratory within one hour. Method I - The tissue, collected in $0,5 \%$ sodium citrate $+0,5 \% \mu \mathrm{g} / \mathrm{ml}$ colcemid, was cut in some pieces and incubated for 1 hour (room temperature).

- With a pair of tweezers the pieces were put in $5 \mathrm{ml} \mathrm{Hanks} \mathrm{BSS} \mathrm{(calcium} \mathrm{and}$ magnesium (ree) in a Petri dish and incubated for 1 hour (room temperature). - A solution of $19 \mathrm{ml}$ Hanks BSS and $6 \mathrm{ml}$ colcemid was added, to obtain a final concentration of $2 \mathrm{~kg}$ colcemid $/ \mathrm{ml}$.

- The tissue was minced immediately in a collector tissue sieve (Bellco Glas Inc. N.Y.) and incubated for 30 minutes at $37^{\circ} \mathrm{C}$.

- Centrifugation at $1000 \mathrm{rpm}, 10$ minutes, and aspiration of the supernatant.

- A prewarmed hypotonic solution of $6 \mathrm{ml}$ foetal calf serum (FCS) (Gibco) and $24 \mathrm{ml} 0,052 \mathrm{M} \mathrm{Kll}$ was slowly added and incubated for 15 minutes at $37^{\circ} \mathrm{C}$. -Centrifugation at $1000 \mathrm{rpm}, 10$ minutes, and aspiration of the supernatants. 
$-30 \mathrm{ml}$ fixative (acetic acid - methanol $3: 7$ ) was slowly added, mixed and incubared for 15 minutes.

- Centrifugation and aspiration of the supernatant were repeated several times.

- Ultimately a cell suspension in about $1 \mathrm{ml}$ fixative remained for slide preparation.

Method II The specimens (collected in Earl's solution) were used for chromosomal analysis according to a modification of the direct technique as described by Arkin and Baker [7]. The modification implied the use of a collector tissue sieve.

For slide preparation cool wet slides were used. The preparations were gently flame dried. From each of the methods, initially three slides were made, stained with Giemsa and evaluated blindly, by two persons. After this check, more slides were prepared. In superficial tumors there is often not more than $\pm 3 \mathrm{~mm}^{3}$ specimen available so a maximum of about 10 slides could be achieved. CBG-banding [8] was performed in all cases. GTGbanding [9] was done if the following criteria were fullilled: if the chromosomes were not fuzzy, not overcontracted, not too elongated and when they were well spread. The age of the slides for GTG-banding was about 1 week; banding was performed with $0.1 \%$ trypsin (Trypsin $1: 250$, Difco).

\section{Results}

With the technique as described under I, recognizable metaphases were present in 25 of the 27 specimens $(93 \%)$. Furthermore, in one of the remaining two cases metaphases were present, but these were not suitable for cytogenetic investigation (Table 1 ).

With the technique as described under II recognizable metaphases were present in 14 of the 27 cases $(52 \%)$. Including the metaphases with insufficient quality for cytogenetic investigation, in 19 of the 27 cases $(70 \%)$ metaphases were found.

Assuming that the cell suspensions of both methods were roughly equal in density, as seen microscopically, the highest metaphase frequency per slide was nearly always seen with method I. In two cases no quantitative differences were observed. In non-infiltrating tumors 2-5 metaphases per slide were present with method 1 , compared with $1-2$ with method II. In deeply infiltrating tumors these counts were $5-10$ and $2-5$ respectively. In general, the chromosomes obtained with method I were better spread and more elongated than with method II. C-banded chromosomes were obtained in 23 cases and G-banded chromosomes in 9 cases. In all of these 9 cases the best G-banded preparations were achieved with method 1 .

Detailed cytogenetic data are published as part of a larger group in a separate article [10].

\section{Discussion}

In a previous study we found recognizable metaphases more frequently in deeply infiltrating tumors than in superficial ones. However, taken together the presence of recognizable and unrecognizable metaphases, regardless of the frequency per slide or per biopsy in superticial and deeply infiltrating tumors, there is no significant difference, as we stated previously [2].

To obtain more recognizable metaphases we focused our attention on the observation that in order to increase the number of metaphases mitotic blocking agents were given 
intravenously by some authors, before resection of the tumor $[1,11]$. Therefore, the application of colcemid in two steps was introduced. Furthermore, an improvement of the direct technique as described by Atkin and Baker [7] was attempted. We used $0.5 \%$ sodium citrate with $0.5 \mathrm{\mu g} / \mathrm{ml}$ colcemid as collecting and transporting medium. The inclusion of colcemid in the sodium citrate solution appeared necessary in our technique, since in the absence of colcemid no recognizable metaphases were found. Before incubation with $2 \mu \mathrm{g} / \mathrm{ml}$ colcemid in Hanks BSS, the cells were incubated in pure Hanks BSS. This appeared to be an essential step.

To receive a cell suspension we preferred mechanical disaggregation of the tumor specimen, than with collagenase many tumor cells appeared to be degenerated [12]. In spite of the fact that with this method, recognizable metaphases were found in $93 \%$ of the specimens, G-banding remains problematic, especially in superficial tumors. The frequency of available metaphases per biopsy in non-infiltrating tumors, in general, is lower than in infiltrating ones. Besides the poor quality of the chromosomes is related to a low percentage of G-banding. IIl-defined, fuzzy chromosomes present a major obstacle in banding $[13,14]$.

This technique, compared with that of Atkin and Baker (method II), in our hands proved its value both with regard to quantity and quality of recognizable metaphases.

In conclusion, there are three essential steps in our technique: colcemid application in two steps, interruption of this treatment with Hanks BSS, and two separated hypotonic treatments. A possible explanation of augmentation of recognizable metaphases by a twostep colcemid treatment may be that a reasonable proportion of cells are arrested in metaphase by the first colcemid action. The colcemid is removed by application of Hanks BSS and a significant number of cells in interphase than enter mitosis. These newly dividing cells will be blocked by the second colcemid treatment. Both rounds of metaphase-arrest act cumulatively and therefore a fair amount of cells in metaphase is obtained. In addition to this quantitative improvement, the quality was significantly increased. Mast probably this is due to the two hypotonic treatments. In particular this appeared to be benedicial for solid tumors.

In our opinion this quick and inexpensive method should be recommended since it gives a high yield of usable metaphases.

We thank Drs R. Schapers and Drs R. Retera, pathologists, Drs J. Scheepers, urologist, for their cooperation; Miss C. Bouten for typing the manuscript; Miss N. Peeters for technical assistance and the board of directors of ZALV, Psychiarric Hospital Venray, and st. Maartens Hospital, for financial support. 
Table 1.

Cytogenetical data of the different methods in relation to tumor stage.

\begin{tabular}{|c|c|c|c|c|c|c|c|c|}
\hline \multirow[t]{2}{*}{ tumor } & \multirow[t]{2}{*}{$\mathrm{T} / \mathrm{G}$} & \multicolumn{2}{|c|}{ Methodl } & \multicolumn{2}{|c|}{ MethodII } & \multicolumn{2}{|l|}{$\mathrm{HMF}$} & \multirow{2}{*}{$\begin{array}{l}\text { nodal } \\
\text { number }\end{array}$} \\
\hline & & al & $\mathrm{b}$ & a & $b$ & 1 & II & \\
\hline 1. & $\mathrm{TaC}_{2}$ & + & + & - & - & + & & 46 \\
\hline 2. & $\mathrm{TaCL}_{2}$ & + & + & H & - & + & & 46 \\
\hline 3. & $\mathrm{TaG}_{2}$ & + & $t$ & + & $t$ & + & & 46 \\
\hline 4. & $\mathrm{TaC}_{2}$ & + & + & $t$ & + & + & & 45 \\
\hline 5 & $\mathrm{TaG}_{2}$ & + & + & + & + & + & 4 & 78 \\
\hline 6. & $\mathrm{TaG2}$ & + & + & - & - & + & & 43 \\
\hline 7. & $\mathrm{TaC}_{2}$ & + & + & - & - & + & & 42 \\
\hline 8. & $\mathrm{TaGl}$ & - & $\ldots$ & - & - & - & - & - \\
\hline 9. & $\mathrm{~T}_{\mathrm{a}} \mathrm{G} 2$ & + & + & + & + & t & & 45 \\
\hline 10. & T1G2 & + & + & + & - & + & & 72 \\
\hline 11. & $\mathrm{~T} 1 \mathrm{G} 2$ & + & + & $t$ & + & tw & & 87 \\
\hline 12 & $\mathrm{~T} 1 \mathrm{G} 2$ & to & + & - & - & + & & 88 \\
\hline 13. & $\mathrm{~T} 1 \mathrm{G} 2$ & + & + & + & - & to & & 43 \\
\hline 14. & $\mathrm{~T} 1 \mathrm{G} 2$ & + & - & - & - & & - & - \\
\hline 15 & TIG2 & + & + & + & - & * & & 84 \\
\hline 16. & $\mathrm{~T} 1 \mathrm{G} 2$ & + & + & + & + & t & & 44 \\
\hline 17 & $\mathrm{~T} 1 \mathrm{G} 2$ & + & + & + & + & + & & 47 \\
\hline 18. & TIG2 & + & + & + & + & H & & 87 \\
\hline 19. & T102 & + & + & + & + & + & & 80 \\
\hline 20 & TIGL & + & + & - & - & + & & 95 \\
\hline 21. & TIG2 & 4 & + & + & - & + & & 43 \\
\hline 22. & $\mathrm{~T} 2 \mathrm{GL}$ & \# & + & + & + & + & + & 85 \\
\hline 23. & $\mathrm{~T} 2 \mathrm{~GB}$ & + & + & - & - & to & & 68 \\
\hline 24. & $\mathrm{~T} 2 \mathrm{G} 3$ & + & + & + & + & + & & 61 \\
\hline 25. & T3G3 & + & + & + & + & + & & 73 \\
\hline 26. & $\mathrm{~T} 3 \mathrm{G} 3$ & + & + & + & + & + & & 73 \\
\hline 27. & $\mathrm{~T} 3 \mathrm{G} 3$ & + & + & + & + & + & & 115 \\
\hline Total + & 26 & 25 & 19 & 14 & & & & \\
\hline
\end{tabular}

Method $\mathrm{I}=$ the method as described in the materials and methods section.

Method II = method of Atkin and Baker [7]

a $\quad=$ recognizable plus unrecogrizable metaphases $(t=$ prescnt $)$.

b = recognizable melaphases.

HMF Highesh Metaphase Frequency per slide. (n case 5 and 22 no difference in metaphase frequency of method I and II was observed).

\section{References}

1. Wijkström H, Granberg-Öhnan I, Tribukait B (T984): Chronosomal and DNA patterns in transitiona coll bladder carcinoma. Cancer 53:1718-1723.

2. Smeets W, Pauwels R, Geraedts I/ (1985): Chromosomal analysis of bladder cancer: Technical aspects. Cancer Genet Cytogenet 16:259:268.

3. Pauwels R, Smeets $\mathbf{W}$, Geraedts J, Debruyne $\mathrm{F}$ ( 1987 ): Cyrogenetic analysis in urathetial cell carcinoma, J Urol 137: 210-215.

4. Sandberg AA (1982): Chromosomes in bladder cancer. American Urological Association. Seminat on Bladder Cancer. Monogr 1: Bladder Cancer. Bonney WW, ed. Williams and Wilkins, Baltimore, pp. 8I-94.

5. Atkin NB, Baker MC (1985): Cytogenetic study of ten carcinomas of the bladder: Involwement of chromosomes 1 and 1.1. Cancer Genet Cylogenet 15: 253-267. 
6. Trent J, Crickard $K$, Gibas $\mathbf{Z}$, Goodacre A, Pathak $\$$, Sandberg AA, Thompson $F$, Whang-Peng I, Wolman $S$ (1986): Methodologic advances in the cylogenetic analysis of human solid rumors. Cancer Genet Cytogener 19:57-66.

7. Atkin NB, Baker MC (1982): Nontandom chromosome changes in carcinoma of the cervix uteri I. Nine near-diploid tumors. Cancer Genet Cytogenet 7: 209-222.

8. Summer AT (1972): A simple technque for demonstrating centric heterochromatin. Exp Cell Res 75 : 304 306.

9. Seabright $M(1971)$ : A rapid banding 1echnique for human chronosomes. Lancel II: $971-972$.

10. Smeets W, Pauwels R, Laarakkers L, Geraedts J, Debruyne F (1987): Chromosomal analysis of bladder cancer. III. Nonrandom alterations. Cancer Genet Cylogenet: in press.

11. Spooner MF, Cooper EH (1972): Chromosome constitution of transitional cell carcinoma of the urinary bladder. Cancer 29: 1401-1412.

12. Smeets AWGB, Pauwels RPE, Beck HLM, Feitz WFJ, Geraedts JPM, Debruyne FMJ, Laarakkers L, Vooys GP, Ramaekers FCS (1987): Comparison of tissue disaggregation techniques of transitional cell badder carcinornas for flow cy tometry and chromosomal analysis. Cyrometry 8: 14-19.

13. Sandberg AA (1982): Chromosomal changes in human cancers: Specificity and heterogeneiry. In: Tumor Cell Heterogeneity: Origins and Implications, wol 4, AH Owens Jr, DS Coffey, SB Barlin, ed. Academic Press, New York, pp. 367.397.

14. Wake N, Slocum HK, Rustum YM, Matsui S, Sandberg AA (I981): Chromosomes and cautsation of human cancer and leukemia. XLIV. A method for chromosome analysis of solid tumors. Cancer Genet Cytogene 3: 1-10. 


\section{Chapter VII}

\section{Chromosomal analysis of bladder cancer. III.}

Nonrandom alterations.

Wim Smeets', Ruud Pauwels, Lisette Laarakkers' ${ }^{1}$, Frans Debruyne ${ }^{3}$ and Joep Geraed ts".

${ }^{1}$ Stichting Ziekenhuisapotheek en Klinisch Laboratorium Venray.

${ }^{2}$ Department of Urology of st. Maartens Hospital, Venlo.

${ }^{3}$ Department of Urology, Radboud Hospital of the Catholic University Nijmegen.

${ }^{4}$ Department of Genetics and Cell Biology of the State University Limburg. 


\section{Abstract}

Chromosome analysis using $\mathrm{G}$ - and $\mathrm{C}$-banding was performed in thirteen primary transitional cell carcinomas of the bladder. The chromosome preparations were obrained by a direct method. In eight tumors with a (near) diploid modal chromosome number the most frequently observed chromosome aberrations were: (partial) monosomy chromosome \# 9 in four cases, deletion of chromosome \#10q in two cases and partial trisomy of chromosome 1 in two cases.

In five tumors with a modal chromosome number in the triploid or tetraploid range the chromosomes \# $1, \# 3, \# 7, \# 9, \# 11$ and \#17 were numerically and or structurally abnormal in at least four cases. In three out of ten males, the $\mathrm{Y}$-chromosome was missing. These findings suggest that the loss of chromosome $\# 9$, and possible also loss of $10 \mathrm{q}$ is a primary event in the karyotypic evolution of transitional cell carcinoma of the bladder.

\section{Introduction}

Chromosome analysis of transitional cell carcinoma (TCC) of the urinary bladder has revealed the involvement of a number of chromosomes. In one study, the presence of an isochromosome i( $5 p)$, an isochromosome i( $8 q)$, deletion and translocation of chromosome \# 8, monosomy \# 9 and interstitial deletion of \# 13 were noticed [1].

Another study reported the involvement of chromosomes \# 1 and \# 11 and to a lesser degree chromosomes \# 3 and \# 17 [2]. Also alterations of chromosomes \#6, and \#13 have been published as non-random abnormalities [3]. Recently deletions of $10 \mathrm{q} 24$ and $21 \mathrm{q} 22$, trisomy \# 7 and aberrations of \#9, \#13, \#15 and \#20 were added to the list of alterations [4].

Hitherto, some dozens of cases are described with successful banding of the tumor chromosomes

After the introduction of a new technique in our laboratory, G-banded chromosomes could be obtained much more frequently during the past [5]. In this report the chromosomal findings of 9 cases, studied with this method, are combined with the results of four patients studied at an earlier date.

\section{Materials and methods}

The tumor samples were collected and transported in $0.5 \%$ sodium citrate $+0.5 \mu \mathrm{g}$ colcemid/ml and prepared as described elsewhere [5].

All tumors were primary tumors. None of the patients, before first resection, received chemotherapy or radiation therapy. Two of them recurred. Further data on the 13 cases are shown in Table 1.

Clinical staging of the tumors was done according to the rules of the Union International Contre le Cancer [6] and grading according to the WHO system [7]. In addition, intermediate tumors were divided in $\mathrm{G} 2 \mathrm{a}$ and $\mathrm{G} 2 \mathrm{~b}$. The latter is less differentiated than the former [8].

In addition to the cells with $\mathrm{G}$ - and $\mathrm{C}$-banded chromosomes, a number of unbanded metaphases could be analyzed. Therefore the chromosomes of at least 15 metaphases of every tumor were counted in order to increase the reliability of the chromosome number. 


\section{Results}

The tumors fell into two groups: those with near diploid modal chromosome numbers (cases 1-8) and those with near tri- or tetraploid modal numbers.

Case 1.: Mode 46. Range 43-90.

Two G-banded and two C-banded metaphases with 46 chromosomes were analyzed. A 10q-[del(10)(q22)] was present. There were some (near) tetraploid cells, which were unsuitable for chromosomal analysis.

The modal karyotype was: $46, \mathrm{XY}$, $\operatorname{del}(10)(\mathrm{q} 22)$.

Case 2.: Mode 46.

All cells counted showed 46 chromosomes.

Two G-banded and two C-banded metaphases were analyzed. One chromosome \# 9 showed a deletion of the long arm 9q-[del(9)(q22?)]. One chromosome \# 12 was missing and one marker chromosome, probably derived from a chromosome \# 12 , was present.

The modal karyotype was: $46, \mathrm{XY}, 9 \mathrm{q}^{-},-12,+$ mar.

Case 3.: Mode 45. Range 44-45.

Five G-banded and two C-banded metaphases were analyzed. Consistent features were monosomy $\# 9$ and $10 \mathrm{q}-[\operatorname{del}(10)(\mathrm{q} 22)]$.

The modal karyotype was: $45, \mathrm{XY},-9$, $\operatorname{del}(10)(\mathrm{q} 22)$.

Case 4.: Mode 47.

All cells, except one, had 47 chromosomes.

Seven G-banded and two $\mathrm{C}$-banded metaphases were analyzed. Consistent features were $2 q-, 9 q+,+i(8 q)$. Furthermore, the short arm of one chromosome \# 8 was probably abnormal.

The single diploid cell showed no karyotypic abnormalities.

The modal karyotype was: $47, \mathrm{XY}, 2 \mathrm{q}-,+\mathrm{i}(8 \mathrm{q}), 9 \mathrm{q}+$.

Case 5.: Mode 46. Range 42-46.

Seven G-banded and two C-banded metaphases were analyzed. Consistent features were an extra chromosome 1.p-[del(1)(p22)] and a missing Y'chromosome.

The modal karyotype was: $46, \mathrm{X},-\mathrm{Y},+1 \mathrm{p}-$.

Case 6.: Mode 44. Range 41-72.

Three $\mathrm{G}$-banded and two $\mathrm{C}$-banded metaphases were analyzed. Missing were one copy of \# 9, \#11, \# 14 and the Y-chromosome.

Two structurally abnormal chromosomes were present: $1 \mathrm{p}$-[probably del(1)(p 13)] and an $11 \mathrm{p}+$ chromosome.

There were some (near) triploid cells, which were unsuitable for chromosomal analysis.

One diploid cell showed no karyotypic abnormalities.

Eleven months after the first resection a biopsy specimen of a recurrent tumor was obtained which showed the same modal karyotype.

The modal karyotype of both resections was: $44, X,-Y,+1 \mathrm{p}-,-9,1 \|_{p}+,-14$. 
Case 7:: Mode 47. Range 44-86.

Three $\mathrm{G}$-banded and two C-banded metaphases were analyzed. In all cells examined trisomy \# 20 was present.

Six months after the first resection, a biopsy specimen of a recurrent tumor at the primary site was obtained which showed the same karyotype.

There were a few near retraploid cells, which were unsuitable for chromosomal analysis.

The modal karyotype of both resections was: $47, \mathrm{XY},+20$.

Case 8.: Mode 42. Range 41-86.

Ten G-banded and two C-banded metaphases were analyzed. Missing chromosomes were one copy of \#3,\#6,\#7,\#17, one X-chromosome and both copies of \# 9. A dicentric translocation, tdic $(7 ; 9)(\mathrm{p} 11 ; \mathrm{p} 11)[7 \mathrm{qter} \rightarrow \mathrm{p} 11:$ : $9 \mathrm{pl} 1 \rightarrow \mathrm{qter}]$ and two marker chromosomes were present. Mar 1, a large marker, was composed of most of a chromosome \# 3 and the short arm (including the centromere) of \#6. Between these parts a homogeneously staining region (HSR) was present. With C-banding the presence of the two centromeres was demonstrated. The composition of this marker is probably: 3 qter $\rightarrow$ pl $3 ;$ HSR; $6 \mathrm{q} 13 \rightarrow$ pter. Mar 2 is a derivative 9 chromosome and is probably a $\mathrm{t}(9 ; 17)(\mathrm{q} 34 ; \mathrm{q} 21$ ? $)$ [9pter $\rightarrow \mathrm{q} 34:: 17 \mathrm{q} 21$ ? $\rightarrow$ qter?].

A cell with 57 chromosomes was also fully karyotyped. The HSR containing marker and two of the dicentric translocation chromosomes as described were present. Besides, a small metacentric marker chromosome was seen.

In the metaphases with about 85 chromosomes, present in 8 out of 60 cells, two HSR containing markers were present. Further karyotyping was impossible. The modal karyotype was: $42, \mathrm{X},-\mathrm{X},-3,-6,-7,-9,-9,+\mathrm{t}(7 ; 9),-17,+$ mar 1 , $+\operatorname{mar} 2$.

Case 9.: Mode 60. Range 52-63.

Six $\mathrm{G}$-banded and two C-banded metaphases were analyzed. Consistem features were: a translocation $\mathrm{t}(1 ; 6)(\mathrm{p} 12 ; \mathrm{p} 12)[6 \mathrm{pter---)} \mathrm{pl} 2:: 1 \mathrm{p} 12$--) lqter], del $2(q 12), 4 p+$, del $9(q 13), 11 p+, 12 p+$, two abnormal derivative 13 and 14 chromosomes, $17 \mathrm{q}+, 19 \mathrm{q}+, 20 \mathrm{q}+$ and three different markers. Chromosomes \#1, \#3, \# 7, and \# 17 were present in triplicate. Chromosomes \# 2 , \#10, \# 12 , \# 14, were present in single copies. No normal \# 13 and \# 14 were seen. The modal karyotype was most probably: $60, \mathrm{XY},+\mathrm{X},+1,+\mathrm{t}(1 ; 6)(\mathrm{pl} 2 ; \mathrm{pl})$, $2 \mathrm{q}-,+3,+4 \mathrm{q}+,+7,+9 \mathrm{q}-,-10,+11 \mathrm{p}+, 12 \mathrm{p}+, 13 \mathrm{p}+, 13 \mathrm{p}+, 14 \mathrm{p}+, 14 \mathrm{p}+$, $+17,+17 \mathrm{q}+,+19 \mathrm{q}+,+20 \mathrm{q}+,+\operatorname{mar} 1,+\operatorname{mar} 2,+\operatorname{mar} 3$.

Case 10.: Mode 83. Range 64-85.

Four G-banded and two C-banded metaphases were analyzed. Consistent features were 5 structurally abnormal chromosomes, three of which could be identified to some extent: $12 q+, 6 q-, 21 p+$ ?. The remaining two were qualified as markers.

Therefore, the modal karyotype was most probably: $83, \mathrm{XX},+\mathrm{X},+1,+2,+3$, $+3,+4,+5,+6,+6 \mathrm{q}-,+7,+8,+8,+9,+10,+10,+11,+11,+12$, $+12 \mathrm{q}+,+13,+14,+15,+16,+17,+17,+18,+19,+19,+20,+20,+21$, $+21,+21 p+?,+22,+22,+\operatorname{mar} 1,+\operatorname{mar} 2$. 
Case 11.: Mode 77. Range 46-87.

Four $\mathrm{G}$-banded and two C-banded metaphases were analyzed. Consistent features were: an extra 1q- [del (1)(q12?)], a large $11 p+$ chromosome composed of most of chromosome \# 11 and the long arm of \# 1 , including the centromere. Berween these two chromosome parts, a HSR was present. The probable composition of this marker was: 1lqter $\rightarrow$ pl 14 ? HSR; 1 p 12? $\rightarrow$ lqter.

Eleven markers varying in length from the $A$ - to $G$-group were present. Most chromosomes were present in triplicate, except for \#2,\#4, \#8, \#10, which were normal, and \# 22 showing four copies.

The modal karyotype was most probably: $77, \mathrm{XX},+1,+1 \mathrm{q}-,+3,+5 ?,+6$, $+7,+9,+11 p+,+12,+13,+14,+15,+16,+17,+18,+19,+20,+21$, $+22,+22,+\operatorname{mar} 1,+\operatorname{mar} 2,+\operatorname{mar} 3,+\operatorname{mar} 4,+\operatorname{mar} 5,+\operatorname{mar} 6,+\operatorname{mar} 7$, $+\operatorname{mar} 8,+\operatorname{mar} 9,+\operatorname{mar} 10+\operatorname{mar} 11$.

Case 12.: Mode 71. Range 53-76.

Two metaphases were completely and three partially karyotyped after $\mathrm{G}$ banding. Two C-banded cells were available. Striking features were: $1 \mathrm{q}-(\mathrm{q} 22)$, $2 q-(q 14), 5 p+, 8 p+, 10 p+, 12 p+$.

Fourteen marker chromosomes, varying in length from the A- to G-group were present.

The modal karyotype was most probably: $71, \mathrm{XY},+\mathrm{Xq}+,+1,+1 \mathrm{q}-,+2 \mathrm{q}-$, $+3,-4,5 \mathrm{p}+,+7,8 \mathrm{p}+,+10 \mathrm{p}+,+11,12 \mathrm{p}+,+13 ?,+17,+17,+21,+\operatorname{mar} 1$, $+\operatorname{mar} 2,+\operatorname{mar} 3,+\operatorname{mar} 4,+\operatorname{mar} 5,+\operatorname{mar} 6,+\operatorname{mar} 7,+\operatorname{mar} 8,+\operatorname{mar} 9,+$ $\operatorname{mar} 10,+\operatorname{mar} 11,+\operatorname{mar} 12,+\operatorname{mar} 13+\operatorname{mar} 14$.

Case 13.: Mode 73. Range 63-79.

Five G-banded and two C-banded metaphases were analyzed. Consistent features were two, and in some cells three, $9 \mathrm{q}+$ chromosomes. It appeared that these derivative chromosomes showed two centromeres, one of which was suppressed [psu dic (9)]. An isochromosome i(2q) and two markers were present.

The modal karyotype was most probably: $73, \mathrm{X},+\mathrm{X},-\mathrm{Y},+1,+1,-2,+\mathrm{i}(2 \mathrm{q})$, $+6,+6 \mathrm{q}-,+7,+8,+8,+$ psu dic $(9),+$ psu $\operatorname{dic}(9),+10,+11,+11,+12$, $+12,+13,+13,+14,+14,+15,+15,+17,+18,+18,+19,+20,+$ mar 1 , $+\operatorname{mar} 2$.

\section{Discussion}

As reported in a previous study, non-infiltrating bladder tumors mostly have a modal chromosome number and a chromosomal range in the near diploid region, whereas infiltrating cancers mostly show hyperdiploidy [9].

In this study representative karyotypes of the modal chromosome numbers or $13 \mathrm{G}$ banded tumors are given.

In three (cases 5,6 and 13) of the ten males the $Y$ chromosome was missing. In bone marrow this is frequently observed and could be an age dependent phenomenon [10]. The ages of our three patients where 54,73 and 90 years, respectively. In three of four primary gastric cancers, recently published, the $Y$ chromosome was missing. The age of these patients was $27,68,54$ years, respectively, whereas in the fourth patient, age 74 the $Y$ 
chromosome was present [11]. Our data suggest that the loss of the $Y$ chromosome is not merely related to age.

The autosomes most frequently involved in strucrural and/or numerical aberrations are in numerical sequence:

Chromosome \# 1: This chromosome was involved in structural rearrangements in 6 cases (Table 2)(Fig. 1). Also, in published series of bladder cancer, chromosome \# 1 frequently underwent structural changes $[2,3,12-14]$. Furthermore, abnormalities of \# $\mathbb{1}$ are reported as occurring in various other types of human neoplasia [15-19]. However, there is much variation in the position of the breakpoints. The eleven recognized breakpoints in the cases of bladder cancer, cited above and in our cases, are between $1 \mathrm{p} 22$ and $1 \mathrm{q} 25$, i.e. in the proximal regions of the chromosome arms, consisting of approximately of half of the entire chromosome.

Chromosome \#2 showed structural changes in four cases: in three a deletion of part of the $q$-arm and in one an i $(2 q)$ were observed. The involvement of chromosome \# 2 is not striking in the reports of previous authors dealing with bladder tumors. On the other hand in malignant melanoma structural aberrations of \#2 are frequent [19].

Chromosome \# 3 was involved in a structural change in one case and in four other cases it was present in triplicate.

Chromosome \# 6 was frequently involved. In case 9 a translocation, $t(1 ; 6)(\mathrm{p} 12 ; \mathrm{p} 12)$, and in case 8 a translocation $\mathrm{t}(3 ; ? ; 6)(\mathrm{p} 13 ;$ HSR; 13$)$, were seen. Trisomy 6 was present in four near triploid cases. In the study of Gibas et al. [3] chromosome \# 6 was affected in five of the nine tumors, mostly as a deletion of the long arm. Deletions of the long arm of chromosome \# 6 are often found in malignant disorders [20]. Involvement of chromosome \# 6 in structural or numerical alterations of the karyotype, was accompanied by other chromosomal changes in all cases including ours. Thus we agree with other authors [3, 21]. that abnormalities of chromosome \#6 most likely are secondary changes.

Chromosome \# 7 was involved in structural rearrangements in one case and in the five near triploid tumors as an additional chromosome. Trisomy 7 has been reported as a possible primary change in TCC of the ureter [4]. In bladder cancer this change was present in two near triploid cases of Atkin and Baker [2] and in one near diploid and one near triploid case of Gibas et al. $\llbracket 1,3 \rrbracket$. Because trisomy \# 7 was absent in our near diploid cases and absent in all (except one) near diploid bladder tumors of the studies cited above, we tend to consider trisomy \# 7 as a secondary change.

Chromosome \# 8 was involved in structural changes in two cases. An isochromosome $\mathrm{i}(8 \mathrm{q})$, as in our case 4 , has been reported before by Gibas et al. $[1,3]$ in two cases.

Chromosome \# 9 was involved in five of the eight near diploid cases: $(9 q-;-9 ; 9 q+;-9 ;-9$, $-9,+t(7 ; 9)$ respectively). Arkin and Baker [2] found a missing \# 9 in three of six near diploid bladder tumors and in one of four strongly hyperdiploid ones.

Gibas et al. [1] reported monosomy \# 9 in three of six near diploid tumors and in one of three near tetraploid cases. In the following study of this authors [3] monosomy \# 9 has been reported in one of four near diploid cases.

Berger et al. [4] found a missing \# 9 in two of six near diploid cases. The case described by Kovacs [13] and the diploid case examined by Vanni et al. [22] also showed a missing \# 9. Taken together, the cited studies and our data, in 14 of 32 near diploid bladder tumors 
chromosome 9 was missing and in two other cases a structural aberration was recognized (Table 3). It is more and more likely that loss of chromosome 9 is a primary change in bladder tumor.

In two cases a deletion of the long arm of 10 , breakpoint at $\mathrm{q} 22$, was present. This is very interesting since Gibas et al. [1] and Berger et al. [4] each reported a patient with a deletion of $10 \mathrm{q}(24)$. The deletion in one of our cases was the sole abnormality, in the other it was accompanied by monosomy \# 9 .

Deletion of \#10 could be a primary change, since it was found in two near diploid tumors.

Chromosome \# 11 was involved at least three times in structural rearrangements; in one case with a near diploid chromosome count and in two near triploid cases. Thus, it appears to us, that chromosome \# 11 is preferentially associated with invasiveness and that it is not inwolved in the initial steps of carcinogenesis of the bladder. Arkin and Baker [2] reported frequent structural changes of \# 11, including short arm deletions. This could be of interest since the oncogene c-Ha-ras 1 is located on 11 p 14 [23]. In our cases we were unable to recognize the breakpoint in \# 11 rearrangements.

Deletions of $11 \mathrm{p}$ are well known to occur in tumor cells of patients with Wilms' tumor [24].

Two of our cases (cases 8 and 11 ) contained homogeneously staining regions (HSR). This phenomenon has been described in a variety of tumors and is related to gene amplification $[25,26]$. It may be a reaction of exposure to drugs [27]. However, our cases were primary tumors and the patients did not receive chemotherapy before resection of the tumors mentioned.

Atkin and Baker [2], using a direct technique, revealed involvement of chromosome \# 11 as structural change in all six near diploid cases. In the eight cases examined by Berger et al. [4], data obtained after enzymatical disaggregation of the specimens and culturing the mallignant cells, no involvement of \# 11 was seen. Our results show an abnormal chromosome \# 11 in one of the near diploid tumors.

The simultaneous application of both methods, to more tumors is necessary to draw conclusions about the significance of chromosome 11 in bladder carcinogenesis.

Chromosome 17 had undergone structural aberrations in two cases and was present in three or more copies in all near triploid cases. The involvement of this chromosome thas been reported before [2].

In one case an additional chromosome \# 20 was seen as a sole abnormality. In a resection specimen obtained six months after the first, the same karyotype was present. Atkin and Baker [2] reported on the presence of one or more extra $\# 20$, together with other chromosomal changes. Berger et al. [4] reported this in two bladder tumors, but an extra $\# 20$ was even more frequently found in renal tumors. "They interpreted trisomy 20 as a possible secondary change.

Our findings confirm those of others in some cases, but it is also clear that differences were observed. The most obvious example is the absence of i( 5 p). This isochromosome was reported by Gibas et al. $[1,3]$ in 7 out of 16 tumors. It cannot be established with certainty that $\mathrm{i}(5 \mathrm{p})$ was missing in our study. For instance, in case 8 a small metacentric chromosome was present which resembles $1(5 p)$ or a deletion of $5 q$ al $q 13$. However, both copies of chromosome \# 5 present were normal. 
In some cases normal diploid cells were present. Presumably, they represent normal stromal, epithelial or muscle cells.

The number of translocations found in this study was low. Furthermore, different breakpoints in different chromosomes were involved. Therefore, specific translocations were not observed.

Reciprocal translocations characterise several forms of leukemia and lymphoma and contribute to the process of neoplastic transformation by activating oncogenes situated close to the breakpoints $[21,28,29]$. Solid tumors in contrast, generally present unbalanced chromosomal changes, rather than reciprocal translocations. This results in duplication or loss of (parts of) chromosomes [30]. This mechanism is relevant for the acquisition of cancer genes in hemizygous form. As suggested by Knudson [31] invisible mutations - which can lead to homozygoty for recessive cancer genes - or loss of genetic material by deletion of (a part of) the chromosomes - which leads to hemizygoty of the recessive cancer gene - can produce cancer, as demonstrated in Wilms' tumor and retinoblastoma. Further support for Knudson's model has been obrained at the DNA level [32].

To find chromosomal changes which are specific or directly related to the origin of the tumors, near diploid tumors are needed, with preferably a few or ideally one chromosome abnormality. In spite of the problem of many chromosome abnormalities in poorly differentiated tumors, it is worthwhile to examine these tumors as well, since possible specific rearrangements could be found, which are indicators for aggressiveness of the tumor [28].

To establish the primary chromosome change, direct cytogenetic examination offers the best chance of success, in spite of the fact that after culturing the cells, banding of the chromosomes is better. Chromosomal changes in vitro and growth advantage of a special cell line include the risk of contradictory data.

This study stresses loss of chromosome 9 as a probable primary change. Deletion of chromosome $10 \mathrm{q}$ at band $\mathrm{q} 22$ is possibly another primary change.

If more well differentiated transitional cell carcinomas of the bladder are chromosomally analyzed, it might be possible to divide bladder cancer in subgroups analogous to the situations in the acute leukemias.

Prospectives in the field of therapeutic approaches and clinical behavior of the tumors also may be improved. 
Table 1.

Summary of the clinical data, range and modall chromosome number.

\begin{tabular}{|c|c|c|c|c|c|}
\hline \multirow[b]{2}{*}{ Ga⿻ } & \multirow[b]{2}{*}{ age } & \multirow[b]{2}{*}{ sex } & \multirow[b]{2}{*}{ stage/grade } & \multicolumn{2}{|c|}{ chromosomes } \\
\hline & & & & range & m. $n$ \\
\hline 1 & 74 & $\mathrm{M}$ & $\mathrm{TaC} 2 \mathrm{~b}$ & $43-90$ & 46 \\
\hline 2 & 64 & $M$ & $\mathrm{TaG}^{\mathrm{T}}$ & 46 & 46 \\
\hline 3. & 80 & $\mathrm{Mi}$ & $\mathrm{TaC2a}$ & $44-45$ & 45 \\
\hline 4. & 33 & $M$ & TaG2b & 47 & 47 \\
\hline 5. & 73 & $M$ & $\mathrm{Ta}(\mathrm{m}) \mathrm{C} 2 \mathrm{a}$ & $42-46$ & 46 \\
\hline $6 \mathrm{~A}$ & 54 & $M$ & $\mathrm{Tl}(\mathrm{m}) \mathrm{Ca} a$ & 41.72 & 44 \\
\hline B. & 55 & $M$ & $\mathrm{TaC}_{2}$ & $41-75$ & 44 \\
\hline $7 A$ & 74 & M & $\mathrm{T} 1 \mathrm{G} 2 \mathrm{~b}$ & $44-86$ & 47 \\
\hline B. & 74 & $\mathrm{ML}$ & $T 1 G 2 b$ & $45-83$ & 47 \\
\hline 8. & 87 & $\mathbb{F}$ & $\mathrm{T} 2 \mathrm{G} 2 \mathrm{~b}$ & $41-86$ & 42 \\
\hline 9. & 74 & $M$ & $\mathrm{~T} 2 \mathrm{G3}$ & $52-63$ & 60 \\
\hline 10. & 79 & $\mathrm{~F}$ & T.26b & $64-120$ & 83 \\
\hline 11 & 67 & $\mathrm{~F}$ & T3G3 & $46-87$ & 77 \\
\hline 12 & 69 & $\mathrm{M}$ & 1303 & $53-76$ & 71 \\
\hline 13 & 90 & $M$ & $\mathrm{~T} 3 \mathrm{G} 3$ & 63.79 & 73 \\
\hline
\end{tabular}

m.n. = modal number of chromosomes.

(m) = multiple amors

Table 2.

Summary of the most frequently involved chromosomes and their abnormalities.

\begin{tabular}{|c|c|c|c|c|c|c|c|c|}
\hline conse & $\mathrm{m} \cdot \mathrm{n}$ & 1 & 3 & 7 & 9 & 10 & 11 & 17 \\
\hline 1. & 46 & & & & & $10 q_{-}^{-}$ & & \\
\hline 2. & 46 & & & & $90-$ & & & \\
\hline 3 & 45 & & & & -9 & $10 \mathrm{~g}-$ & & \\
\hline 4 & 47 & & & & $99+$ & & & \\
\hline 5. & 46 & $+1 p-$ & & & & & & \\
\hline 6 & 44 & $+1 \mathrm{p}-$ & & & -9 & & $11 p+$ & \\
\hline 7. & 47 & & & & & & & \\
\hline \multirow[t]{3}{*}{8} & 42 & & -3 & -7 & -9 & & & \\
\hline & & & $(3 ; H ; 6)$ & $1(7 ; 9)$ & -9 & & & \\
\hline & & & & & $19 ; 17)$ & & & -17 \\
\hline \multirow[t]{2}{*}{9} & 60 & $+1(1 ; 6)$ & $4-3$ & +7 & $+9 \mathrm{q}$ & -10 & $+11 p+$ & +17 \\
\hline & & + & & & & & & $+176+$ \\
\hline \multirow[t]{2}{*}{10} & 83 & +1 & +3 & +7 & +9 & +10 & +11 & $* 17$ \\
\hline & & & +3 & & & +10 & +11 & +17 \\
\hline \multirow[t]{2}{*}{11} & 77 & $+19-$ & +3 & +7 & +9 & & $+1(11 ; 11 ; 1)$ & +17 \\
\hline & & +1 & & & & & & \\
\hline \multirow[t]{2}{*}{12} & 71 & $+19-$ & +3 & +7 & & $+10 p+$ & +11 & H* 17 \\
\hline & & +1 & & & & & & +17 \\
\hline \multirow[t]{2}{*}{13.} & 73 & +1 & & +7 & $+9 q+$ & -10 & +11 & +17 \\
\hline & & +1 & & & $+9 q+$ & & +11 & \\
\hline
\end{tabular}


Table 3.

Summary of the near diploid tumors and the most frequently involved chromosomes.

\section{A. Culture method:}

\begin{tabular}{|c|c|c|c|c|c|c|c|c|c|c|c|}
\hline \multirow[t]{2}{*}{ author(s) } & \multirow{2}{*}{$\begin{array}{l}\text { all } \\
\text { itum. }\end{array}$} & \multirow{2}{*}{$\begin{array}{l}\text { dipl. } \\
\text { tum. }\end{array}$} & \multirow{2}{*}{ case } & \multirow[t]{2}{*}{$\mathrm{m}, \mathrm{n}$. } & \multicolumn{7}{|c|}{ chromosome involwed } \\
\hline & & & & & 1 & 5 & 6 & 8 & 9 & 10 & $\mathbb{1 1}$ \\
\hline \multirow[t]{6}{*}{ Gibas: 4} & 9 & 6 & 1 & 48 & & $+i(5 p)$ & & $\mathrm{i}(8 \mathrm{q})$ & & & \\
\hline & & & 2 & 45 & $p+$ & & $q-$ & & -9 & $p+$ & -11 \\
\hline & & & 3 & 44 & & & & $\mathrm{p}-$ & & $9+$ & \\
\hline & & & 5 & 47 & & & & & -9 & & \\
\hline & & & 6 & 47 & & $+1(5 p)$ & $q-$ & & & $q-$ & \\
\hline & & & 7 & 45 & & & & & -9 & & \\
\hline \multirow[t]{5}{*}{ Gibas 86} & 7 & 4 & 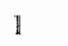 & 45 & $q+$ & & & & -9 & & \\
\hline & & & 2 & 47 & & & & & & & \\
\hline & & & 3 & 43 & $\mathrm{p}+; \mathrm{q}-$ & $i(5 p)$ & qow & & & & $p-i p+p^{n}$ \\
\hline & & & 5 & 48 & & $q-$ & $:(6 ; X)$ & & & & $1(11 ; 13)$ \\
\hline & & & & & & & & & & & $q_{m}$ \\
\hline \multirow[t]{6}{*}{ Berger' 86} & 8 & 6 & 1 & 46 & & & & $\mathrm{p}-$ & \multicolumn{2}{|l|}{$-9 ; i(9 q)$} & \\
\hline & & & 2 & 45 & & & & & & & \\
\hline & & & 3 & 46 & & & & & & & \\
\hline & & & 4 & 46 & & & & & & $q-$ & \\
\hline & & & 6 & 46 & & & & & -9 & & \\
\hline & & & 7 & 47 & & & & & & & \\
\hline
\end{tabular}

B. Direct method:

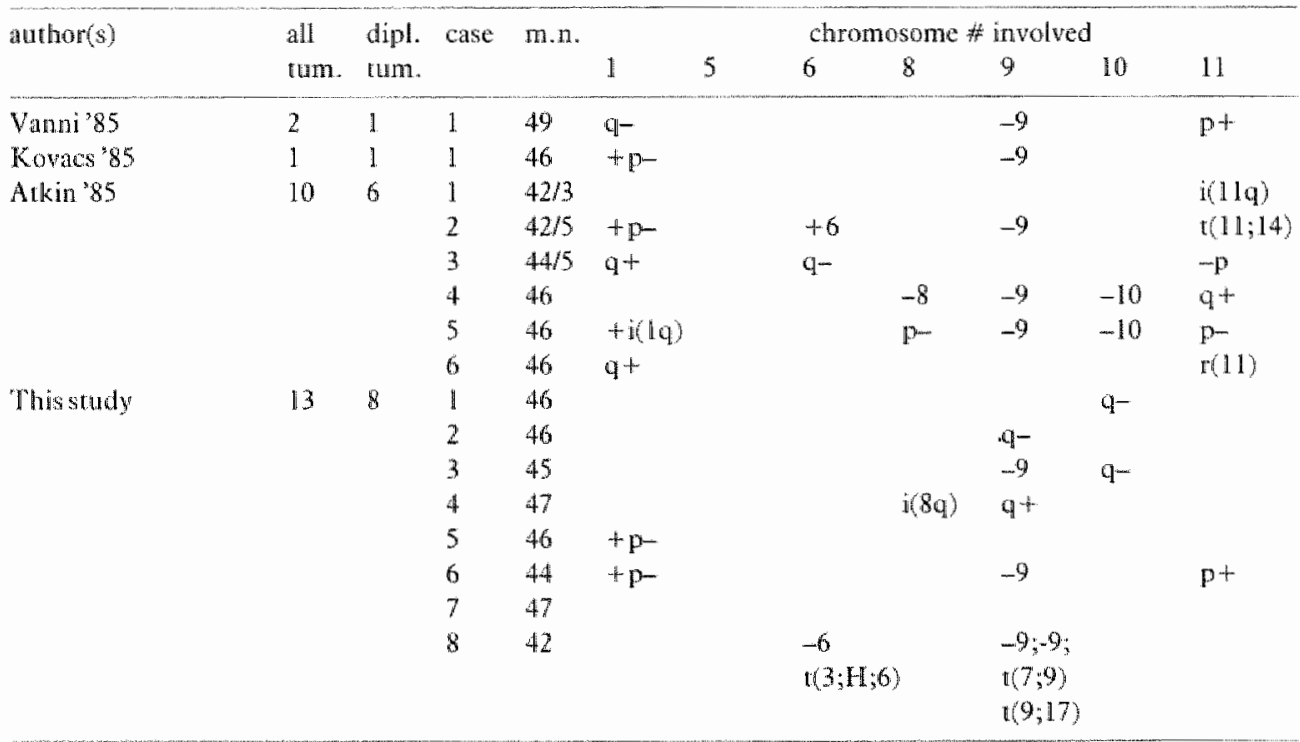

Allwam. : patients examined; near diploid and strongly byperdiploid tumors.

dipl. num. : number of tumors with an near diploid chromosome number.

m.th. :modal number. 


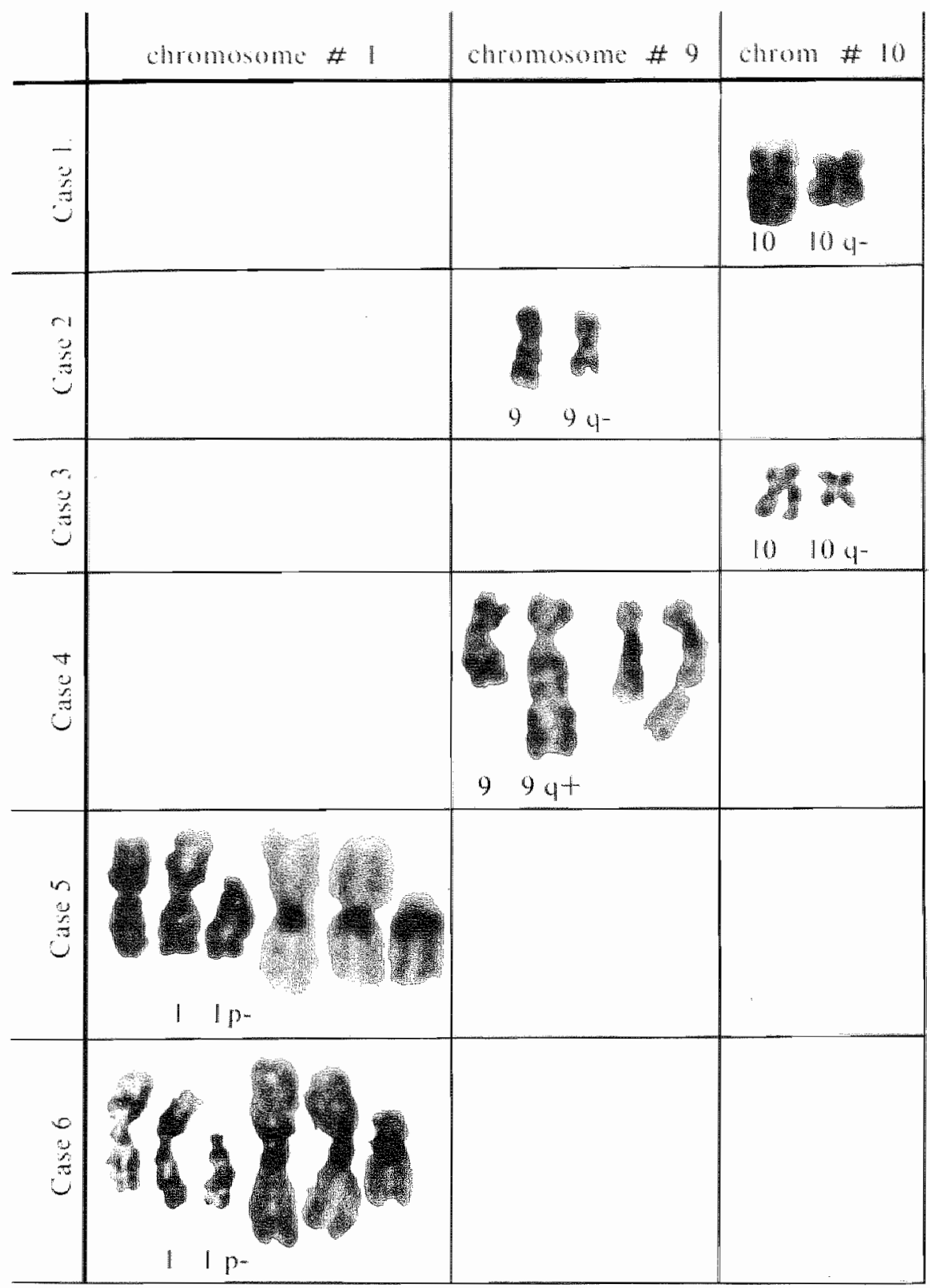

Fighire 1

Structural abnomal G-banded chromosomes derived from 1 , 9 , 10 and wo HSR containing chromosomes. In a rumber of cases the C-banded chromosomes are placed on the right side. 


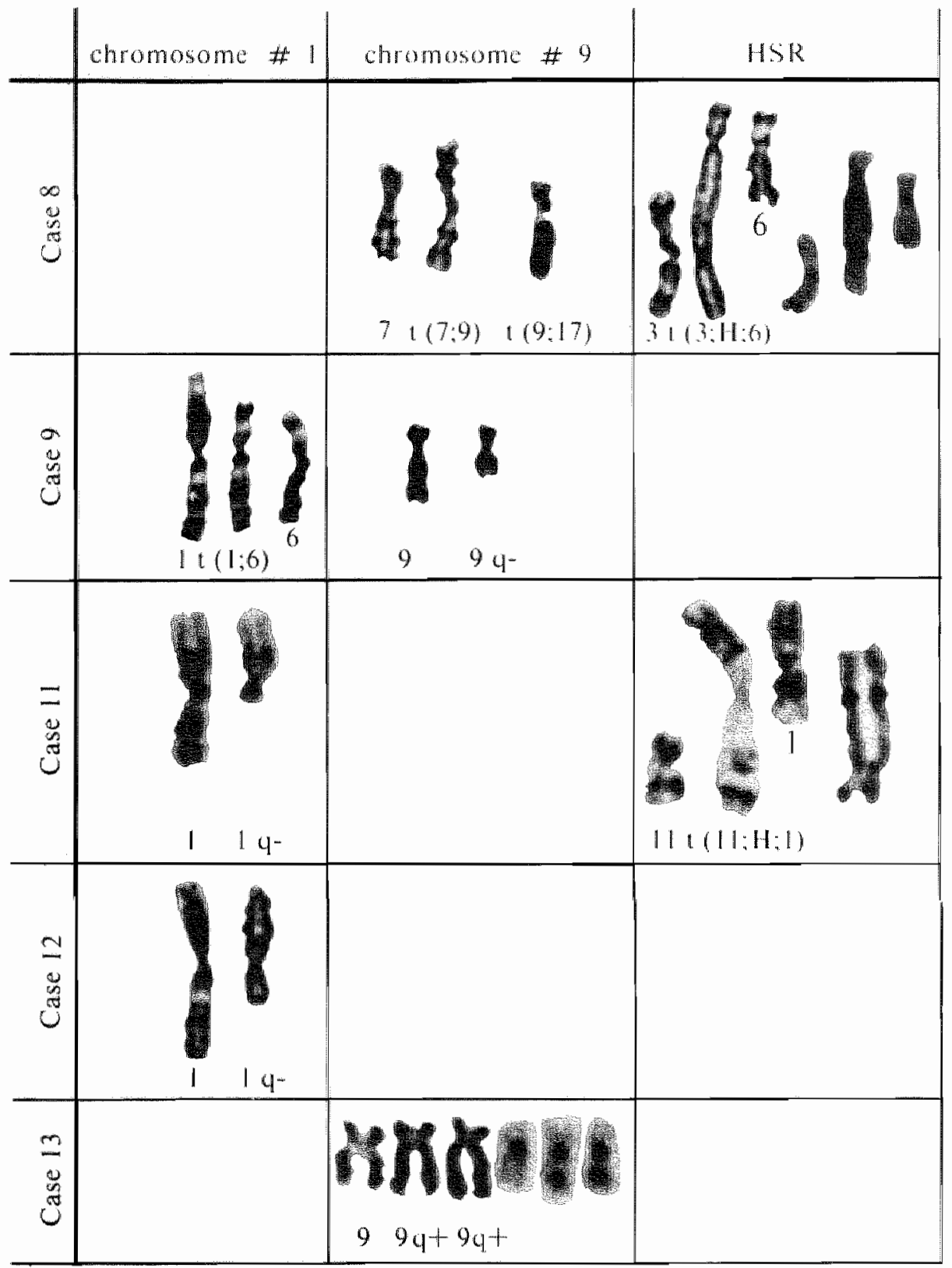

Structural abnormal G-banded chromosomes derived from \# 1 , \# 9 , 10 and two HSR containing chromosomes. In a number of cases the C-banded chromosomes are placed on the right side. 


\section{References}

1. Gibas Z, Prout GR jr, Connolly JG, Pontes $\int E$, Sandberg AA (1984): Nonrandon chromosomal changes in transinional cell carcinoma of the bladder. Cancer Res 44: 1257-1264.

2. Atkin NB, Baker MC ( $\mathbf{9 8 5}$ ): Cytogenetic study of ten carcinomas of the bladder: Involventent of chromosomes 1 and 11. Cancer Gener Cytogenet 15:253-268.

3. Gibas Z, Prout GR jr, Pontes JE, Connolly JG, Sandberg AA (1986): A possible specific chromosome change in transitional cell carcinoma of the bladder. Cancer Genet Cyrogener 19:229-238.

4. Berger CS, Sandberg AA, Todd IAD, Pennington RD, Haddad FS, Hecht BK, Hecht IF (r986): Chromosomes in kidnes, ureter, and bladder cancer. Cancer Genet Cytogenet 23: 1-24.

5. Smeets W, Pauwels R, Laarakkers L, Geraedts J, Debruyne F (I987): Chromosomal analysis of bladder cancer. II. A practical method. Cancer Genet Cytogenet. In press.

6. Harmer MH (ed.) (1978): TNM classification of malignant tumours. Third edition, pp. 113-1.17, U/CC, Geneva.

7. World Health Organization (1973): Histological typing of urinary bladder tumours. In: International Histological Classification of Tumours, no. 10, WHO, Geneva.

8. Pauwels RPE, Schapers RFM, Smeets AWGB, Geraedts JPM, Debruyne FM] (1987): Grading in superficial bladder cancer. 1. Morphological criteria. Bric J Urol. In press.

9. Pauwells RPE, Smeets AWGB, Schapers RFM, Geraed ts JPM, Debruyne FMJ (1987a): Grading in supenficial bladder cancer. 2. Cylogenetic classification. Brit J Uroh. In press.

10. Sandberg AA (1980): The chromosomes in human cancer and leukemia. Elsevier North Holland, Now York, pp. 216-225.

11. Ochi H, Douglass HO jr, Sandberg AA (1986): Cytogenetic studies in primary gastric cancer. Cancer Genet Cytogenet 22: 295-307.

12. Kovacs $\mathbf{G}$ ( $\mathbf{1 9 7 8 )}$ : Abnormalities of chromosone no. 1 in human solid malignant tumors. In J Cancer 21 : 688-694.

13. Kovacs $G$ ( 1985 ): Serial cytogenetic analysis in a patient with pseudodiploid bladder cancer. J Cancer Res Clin Oncol 110: 249-251.

14. Sandberg AA (1986):Chromosome changes in bladder cancer Clinical and other cortelations. Cancer Genet Cynogenet 19: 163-175.

15. Pathak S (1980): Cytogenetic analysis in human breast tumors, Cancer Cenet Cytogenet 1: 281-289.

16. Atkin NB, Baker MC (1982): Nonrandom chromosome changes in carcinoma of the cervis uteri. I. Nine near-diploid tumors. Cancer Genel Cytogenet $7: 209-222$.

17. Gilbert F, Balaban $G$, Moorhead P, Bianchi D, Schlesinger H (1982): Abnormalitice of chromosome $1 \mathrm{P}$ in human neuroblastoma tumors and cell lines. Cancer Gerwet Cyrogenet 7: 33-42,

18. Martinville de B, Cunningham JM, Murray MJ, Francke U (1984): The N-ras oncogenc assigned to the short arm of human chromosome 1 . Nucleic Acids Res $11: 5267-5275$.

19. Pederson MI, Bennett JW, Wang N (1986): Nonrandom chromosome strucuiral abertations and oncogenc loci in human malignant melanoma. Cancer Genet Cytogenet 20:11-27.

20. Bullerdiek J, Bartnitzke $S(1985)$ : The deleted long arm of chromosome 6 : A secondary chromosonnc abnormality in solid tumors and lack of congenital aberrations monosomic for part of the critical segment? Cancer Gienet Cytogenet 18: 183-185.

21. Yunis JJ (1983): The chromosomal basis of human neoplasia. Science 221: 227-236.

22. Vanni R, Peretti D, Scarpa $\mathbf{R M}$, Usai $\mathbf{E}$ (1985): Derivatwe 1 1 marker chromosome in bladder carcinoma. Cancer Genet Cylogenet 16: 289-295.

23. Pimentel E (1985): Oncogenes and human cancer. Cancer Gener Cytogener $14: 347-368$. 
24. Slater RM, de Kraker J (rg8z): Chromosome number 11 and Wilms' numor. Cancer Gener Cyrogener 5 : $237-245$.

25. Kovacs $G$ (1979): Homogencously staining regions on marker chronosomes in malignancy. In I Cancer 23: 299-301.

26. Gebhart E, Tulusan AH, Maillot KV, Mulz D (1983): Double minutes - new markers in cells of human solid tumors. J Genet Hum 31: 45-47.

27. Wolman SR (1986): Cytogenetic heterogeneiry: It role in tumor evolution. Cancer Genet Cytogenet 19 : $129-1401$.

28. Sandberg AA ( 9983$)$ : A chromosomal hypothesis of oncogenesis. Cancer Gener Cytogenet 8: 277-285.

29. Rowley JD (1984): Biological implications of consistent chromosome rearrangements in Jeukemia and lymphoma. Cancer Res 44: 3159-3168.

30. Atkin NB (1986): Lack of reciprocal translocations in carcinomas. Cancer Gener Cytogenet 21:275-278.

31. Knudson AG (r983): Hereditary cancers of man. Cancer Invest 1: 187-193.

32. Cavenee WK, Dryja TP, Phillips RA, Benedict WF, Godbout R, Gallie BL, Murphree AL, Strong LC, Whitte RL ( 1983 ): Expression of recessive alleles by chromosomal mechanisms in retinoblastoma. Nature 305: 779.784 . 


\section{Chapter VIII}

\section{General discussion}

The aim of the present study was to obtain more information about the biology of bladder cancer on the basis of chromosomal analysis and DNA estimations.

\section{Improvements of chromosomal preparations.}

For chromosomal analysis, different steps in the preparative procedure leading to metaphase spreads were tested and improved. Three techniques for cytogenetic examination of neoplastic tissues can be distinguisted: direct technique $[6,19,26]$; short term culture $[18,23]$ and long term culture [9]. Each of these techniques has a variety of modifications, developed in a period of years. In the initial phase of our study all three techniques were applied showing that in $42 \%$ of all tumors examined recognizable chromosomes could be obtained. In superficial tumors this was the case in $37 \%$, while in deeply infiltrating lesions $62 \%$ of the samples gave recognizable chromosomes. If all metaphases were considered, irrespective of the quality, in $52 \%$ to $94 \%$ of the specimens, depending on the technique applied, chromosomes were found. When the direct technique and the short term culture of the same tumor specimens were compared, more metaphases were found with the latter technique. However, despite the higher metaphase frequency after short term culture, we prefer the direct method, since, the risk of chromosomal changes and selection of certain cell types during culture is present $[11,14$, 30].

A requirement for the direct method is the preparation of a single cell suspension, for which currently two methods are in use, i.e. mechanical disaggregation $[1,14,29]$ and enzymatical treatment, with for instance collagenase II [3,30]. Wake et al. [30] found that the use of the latter method yielded more metaphases after culturing the cells for at least 60 hrs compared with mechanical treatment of the tissue. However, no bladder tissue was used in their study. Our results with bladder tumor cells and a culture time between 24 $48 \mathrm{hrs}$ were quite the opposite. Besides, after examination for cell morphology, it appeared that the enzymatic method had a degenerative effect on the tumor cells.

On the first international workshop on chromosomes in solid tumors [27], it appeared that most of the laboratories are using enzymatic tissue disaggregation and afterwards cell culture. However, none of the techniques presented there was completely successful in obtaining analyzable chromosomes. The general consensus of the workshop was that both direct and short term culture must be used.

Owing to technical improvements, at present $93 \%$ of the tumor specimens received, show recognizable and countable chromosomes with our direct technique. Three conditions appear essential to obtain this result: colcemid application in two steps, interruption of colcemid treatment with Hanks BSS solution and two separated hypotonic treatments. Nevertheless, G-banding, or another banding technique with adequate resolution remains a problem. As stated by Trent [27] all workers in the field of cytogenetics have this problem. 


\section{The relation between aneuploidy and tumor behavior.}

The 92 newly diagnosed tumor specmens examined between 1980 - 1986, which yielded recognizable chromosomes, were related to the stage and the grade of the tumor. Of the non-invasive (Ta) tumors, $88 \%$ had a modal number of $\leqslant 49$ chromosomes. In T1 tumors this figure was $43 \%$ and in T2-T4 tumors only $19 \%$.

Taking the chromosomal range as criterion it appeared that all infiltrating ( $T 1$ - $T 4$ ) tumors showed cells with more than 49 chromosomes, compared to $22 \%$ of the non-infiltrating tumors. These differences in chromosome number and chromosome range between noninvasive and invasive tumors were significant. Of the grade 1 tumors $97 \%$ had a modal chromosome number $\leqslant 49$, compared to $49 \%$ of the $\mathrm{G} 2$ and $8 \%$ of the $\mathrm{G} 3$ tumors. The differences in chromosome number and chromosome range between $\mathrm{G} 1$ tumors on the one hand and G2 plus $\mathrm{G} 3$ tumors on the other hand were also significant. Besides, significantly more G3 tumors showed a modal number $>49$ as compared to G2-lesions. Tumors with a chromosomal range of $\leqslant 49$ recur much later than tumors with $>49$ chromosomes. Progression occurs significantly more frequently in tumors with a chromosome range $>49$.

In previous examinations it was found that in high graded bladder tumors much more chromosomes per cell were present as compared to low graded tumors [26]. In invasive tumors the modal chromosome number varied from hypodiploid to hypertetraploid and frequently these tumors contained marker chromosomes [7, 24].

\section{Marker chromosomes.}

Some authors $[7,24]$ have concluded that, if marker chromosomes are present in noninvasive cancers, recurrence will take place in $90 \%$. When marker chromosomes are absent recurrence will take place in less than $5 \%$. The 5 -years survival rate was $40 \%$ when markers were present, as compared to $95 \%$ when markers were absent in non-invasive cancers [24]. It was proposed that the triad markers, tetraploidy and submucosal inwasion in moderately well differentiated tumors appeared to carry such a poot prognosis that radical resection of the bladder was indicated [7].

However, recurrence was not limited to tumors with markers or aneuploidy [5].

Granberg-Ohman [14] postulated that the occurrence of marker chromosomes is related to the histopathological pattern. In our study, the predicting value of marker chromosomes as established by routine techniques, appeared not to be better than the predicting value based on chromosome numbers.

It is my opinion, that the significance of markers has been exaggerated in the past. Only one of the thirteen cases examined for this thesis did not show a structural abnormal banded chromosome. The other cases showed at least one, but sometimes many abnormal chromosomes, which without banding would have been called marker chromosomes, if recognized at all.

The low frequency of abnormal chromosomes in cells of well differentiated tumors as reported in the past may be explanined by technical shortcomings of chromosome identification.

Possibly primary changes related with bladder cancer are a loss of chromosome \# 9 and deletion $10 \mathrm{q} 22[25]$, and isochromosome $\mathrm{i}(5 \mathrm{p})$ as mentioned by Gibas [11, 12]. Other frequently involved chromosomes in near diploid bladder cancers are \# 11 [1] and \# 1 $[17,29]$. It is striking that, unlike the situation in several forms of leukemia and 
lymphoma, in bladder cancers no consistent reciprocal translocations are found. The loss or duplication of (parts of) chromosomes is probably relevant for the acquisition of homoor hemizygoty for recessive cancer genes, as suggested by $\mathbb{K}$ nudson [15].

\section{Flow cytometry.}

Flow cytometric DNA estimations are regarded as an important method for examination of bladder cancer [13]. The mass of DNA can be used as an additional parameter in patient treatment $[28,31]$. To obtain single cell suspensions, mechanical and enzymatical. disaggregation of the tissue were compared with respect to DNA index and percentage of diploid cells in the resulting suspensions. Few studies comparing different disaggregation techniques and their usefulnes for FCM are available $[4,10]$. After mechanical treatment, all the cases were suitable for DNA estimation, compared to $88 \%$ of the enzymatically disaggregated tumors (collagenase II). The DI after mechanical and enzymatical disaggregation was identical. More diploid cells were present in the sample after enzymatical treatment, possibly due to release of stromal cells.

For discriminating epithelial from non-epithelial cells we applied antibodies to cytokeratin in order to increase the discriminating power of flow cytometry $[8,22]$. Thus, the percentage of epithelial cells in $\mathrm{S}$ - and $\mathrm{G}_{2} \mathrm{M}$ phase could be estimated more accurately. Although labeling with antibodies did increase the sensitivity of the FCM technique in detecting tumors with an abnormal DNA mass or abnormal proliferative fractions, the discriminating power of chromosomal analysis appeared to be greater than that of FCM. Tumors with a near diploid chromosome count, translocations, or small aberrations, which do not change the mass of DNA rigorously, can not be recognized by flow cytometry.

\section{Application of chromosomal analysis in daily urological practise.}

When the aim of chromosomal analysis of bladder cancer in daily practise is to determine the modal chromosome number and range, these data can be obtained in about $90 \%$ of all specimens. When the aim is to karyotype the tumor specimen after adequate chromosomal banding, this can be achieved in only $30 \%$ of the cases

In well- and moderately well differentiated superficial rumors chromosomal data are informative with respect to tumor behavior. These chromosome data show that tumors having a chromosome range $\leqslant 49$, recur later than tumors with $>49$ chromosomes. These latter tumors more often show progression. This could imply that after endo-resection of the tumors with $\leqslant 49$ chromosiomes, chemotherapy could be omitted and that the patient could be checked after a longer interval. Tumors having $>49$ chromosomes need extra attention of the clinician. In classifying tumors there is a discrepancy in grading among pathologists $[16,20,21]$. Chromosome numbers as counted and photographed are objective criterions. When a discrepancy in chromosomal count and histopathological data is found, reexamination of the tissue slide is recommended.

\section{Prospectives of future studies.}

The sensitivity of flow cytometry can be increased by application of monoclonal antibodies and other improvements to achieve reliable DNA estimations and proliferative data of the tumor cells. Patients with superficial bladder cancers must be followed over years and the clinical parameters such as multiplicity, recurrence rate and progression should be 
correlated with flow cytometric data. Combination of these data with clinical behavior could result in a malignancy index which may be helpful to obtain a correct prognosis [2]. In search of primary changes of the chromosomes only some dozens of bladder cancers are examined after adequate chromosome banding so far. Already this small number gave indications that some chromosomal aberrations are primary changes. To get certainty, it is necessary to augment the number of cases analyzed. Besides, this gives the possibility to divide bladder cancers in subgroups, depending on their chromosomal abnormalities. In future studies, chromosomal aberrations have to be correlated with the clinical followup of the individual patients with the aim the ultimate use of such chromosomal changes as prognostic factors.

\section{References}

1. Atkin NB, Baket MC (1985): Cytogenetic study of ten carcinomas of the bladder: Involvement of chromosome 1 and 11. Cancer Gener Cytogener 15: 253-268.

2. Baisch H, Otlo U, Kloppel G (1986): Malignancy index based on flow cytometry and histology for renal cell carcinomas and its correlation to progmosis. Cytometry $7: 200-204$.

3. Berger CS, Sandberg AA, Todd IAD, Pennington RD, Haddad FS, Hecht BK, Hecht F ( 1986$)$ : Chromosomes in kidney, ureter and bladder cancer. Cancer Genet Cytogener 23: 1-24.

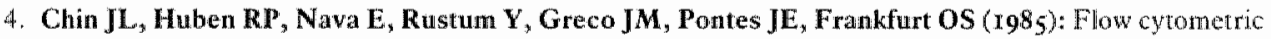
andysis of DNA content in thuman bladder tumors and irrigation fluds. Cancer 56: 1677-1681.

5. Dagg K, Roy JB, Bottomley RH (1980): In: Sandberg AA (1986): Chromosome changes in bladder cancer: Clinional and ofler concelations. Cancer Gene Cytogenet 19: 163-175.

6. Falor WH, Ward RM (1973): DNA banding pattern in carcinoma of the bladder. I Am Med Assoc 226: $1322-1327$.

7. Falor WH, Wand RM (1978): Prognosis in early arcinoma of the bladder based on chromosomal analysis. Jrol 119:44-48.

8. Feitz WFJ, Beck HLM, Smeets AWGB, Debruyne FMJ, Vooijs GP, Herman CJ, Ramaekers FCS (1985): Tissuc-specifo markers in fow cyenciry of tological cancers: Cy cokeratin in bladocr carcinoma. Inu J Cincer $36: 349-356$.

9. Fogh J (1975): Human rumbr cells in viro. Plenum Press. New York pp. 1-557.

10. Frankfurt OS, Sloctm HK, Rostum YM, Arbenck SG, Pavelic ZP, Petrilli $N$, Huben RP, Pontes EJ, Greco WR (1984): Flow cy tometric analysis of DNA aneuploidy in primary and metastat human solid. tunors. Cytometry $5: 71-80$.

11. Gibas Z, Prout GR jr, Connolly JG, Pontes JE, Sandberg AA (1984)" Nonrandom chromosomal changes in transitional cell carcinoma of the bladder. Cancer Res 44: 1257.1264.

12. Gibas Z, Prout GR jr, Pontes JE, Connolly JG, Sandberg AA ( 1986); A possible specific chromosome change in transitional cell carcinoma of ho badder. Cancer Genet Cyogenet 19:229-238.

13. Granberg-Önman 1, Tribukait B, Wijkström H, Berlin T, Collste L (1980): Papillary carcinoma of the urimary bladder. A study of chromosomal and cytofluorometric DNA analysis. Urol Res 8:87-93.

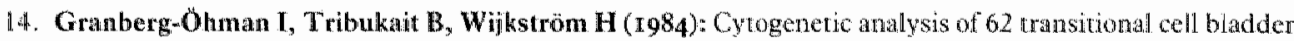
carcinomas. Catmer Gener Cytogenat 11:69-85.

15. Kundson AG (1983): Hareditary cancers of man. Cancer Invest 1: 187-193.

16. Koss LG (1975): Tumor of the arinary bladder. In: Atlas of Tumor Pathology, 2nd. serics, fasc. 11 , pp. 19.43. Fid. Armed Fores Institute of Parhology, Washington, D.C. 
17. Kovacs $\mathrm{G}(\mathbf{1 9 8 5})$ : Serial cytogenetic analysis in a patient with peudodiploid bladder cancer. WCancer Res Clin Oncol 110: $249-251$.

18. Kusyk CJ, Edwards CL, Arrighi FE, Romsdahl MM (1979): Improved method for cyogenetio studies of solid tumors. J Natl Cancer Inst 63: 1199-1203

19. Lamb D (1967): Correlation of chromosome counts with histological appearances and prognosis in transitional-cell carcinoma of bladder. Brit Med J 1: 273-277.

20. Ooms ECM, Andersson WAD, Alons CL, Boon ME, Veldhuizen RW (1983): Analysis of the performance of pathologists in the grading of bladder tumors. Human Pathology 14: 140-143.

21. Pauwels RPE, Schapers RFM, Smeets AWGB, Geraedts JPM, Debruyne FMJ ( 1987 ): Grading in superhicial bladder cancer. 1. Morphological criteria. Brit I Utol. In press.

22. Ramaekers FCS, Beck HLM, Vooys GP', Herman CJ ( 1984$)$ ) Flow cytometric analysis of mixed cell populations using intermediate filament antibodies. Exp Cell Res 153:249.253.

23. Sandberg AA (r.977): Chromosomal markers and progression in bladder cancer. Cancer Res 37:222-229.

24. Sandberg AA (1986): Chromosome changes in bladder wancer: Clinical and other correlation. Cancer Genet Cytogenet 19: 163-175.

25. Smeets W, Pauwels $\mathbf{R}$, Laarakkers $\mathbf{L}$, Debruyne $\mathbf{F}$, Geraedts J ( 1987 ): Chnomosomal analysis of bladder cancer. II. Nonrandom alterations. Cancer Genet Cytogenel. In press.

26. Spooner $\mathbf{M E}$, Cooper $\mathbf{E H}$ (1972): Chromosome constiturion of transitional cell carcimoma of the urinary bladder. Cancer 29: 1401-1412.

27. Trent J, Crickard K, Gibas Z, Goodacre A, Pathak S, Sandberg AA, Thompson F, Whang-Peng J, Wolman S (1986): Methodologic adwances in the cytogenetic analysis of tuman solid tumors. Cancer Genct Cylogenet 19:57-66.

28. Tribukait B, Gustafson H, Esposti PL ( 1982 ): The significance of ploidy and proliferation in the clinical and biological evaluation of bladder tumors: A study of 100 untreated cases. Br J Urol 54: 130-135.

29. Vanni R, Pereti D, Scarpa RM, Usai E (1985): Derivative 11 marker chromosome in bladder carcinoma. Cancer Gener Cytogener 16:289-295.

30. Wake N, Slocum HK, Rustum YM, Matsui SI, Sandberg AA (1981): Chromosomes and catasation of human cancer and leukemia. XLIV. A method for chromosome analysis of solid tumors. Cancer Genet Cytogenet 3: 1-10.

31. Wijkström $\mathrm{H}_{2}$ Granberg-Öhman I, Tribukait B (1984): Chromosomal and DNA patcern in transitional cell bladder carcinoma. A compararive cyogenetic and now cywofuorometric DNA study. Cancer 53: 1718 . 1723. 


\section{Chapter IX}

\section{Summary}

Transitional Cell Carcinoma (TCC) of the urinary bladder has an unpredictable natural history with respect to recurrence and progression. In the daily urological practice the most important diagnostic and prognostic factors of this cancer are its stage and grade as established by histopathological examinations. More information, especially about the prognosis, is required. Chromosomal analysis and DNA-flow cytometry are considered as important methods for a further elucidation of the biological properties of bladder cancer. In this study investigations on chromosomal changes and DNA content of bladder tumor cells are described. The first goal was to develop a useful technique to obtain recognizable chromosomes from as many tumor specimens as possible. Initially in only $42 \%$ of the tumor specimens examined, chromosomes were recognized, mainly after short term culture. A more reliable technique is described in this thesis resulting in recognizable chromosomes in $93 \%$ of the tumors.

To obtain single cell suspensions from the solid tumor specimens, for flow cytomerry as well as for chromosomal analysis, mechanical treatment appeared better than enzymatical disaggregation.

The chromosomal data were correlated with the histopathological classification of the tumor and with the clinical course of the patient. In non-invasive tumors (Ta) almost exclusively cells in the near diploid region ( $\leqslant 49$ chromosomes) were found, in contrast to invasive (T1-T4) lesions, which showed strongly hyperdiploid chromosome numbers ( $>$ 49). In well differentiated tumors (G1) the vast majority of cells was in the near diploid region, and in poorly differentiated (G3) tumors in the strongly hyperdiploid region. In intermediate tumors (G2) both groups were present. Near diploid tumors recur much later than the hyperdiploid cases. Progression of the tumor is observed significantly more often in tumors with hyperdiploid cells than in near diploid lesions.

The discriminating power of flow cytometry after labeling the cells with antibodies to cytokeratin was better than without labeling. After use of these antibodies the percentage of cells in the different phases of the cell cycle could be estimated reliably. However, the tumors with an abnormal karyotype but with a chromosome number in the near diploid range, could not be discriminated by flow cytometric estimations.

Non-random chromosome aberrations were established after banding the chromosomes of the tumor cells. The loss of chromosome \#9 and deletion of a part of chromosone \#10 seem primary alterations in the process of bladder oncogenesis. Aberrations in number or structure of the chromosomes \#1, \#7, \#11 and \#17 are possibly secondary steps in the development of bladder cancer. 


\section{Samenvatting}

Zowel het recidiveren als de progressie in groei van kanker van het overgangsepitheel van de urineblaas is onvoorspelbaar. In de urologische praktijk worden tumorstadium en tumorgraad, zoals vastgesteld doot histopathologisch onderzoek, als belangrijkste diagnostische en prognostische factoren gehanteerd. Met name met het oog op verbetering van de prognose is het verwerven van meer gegevens van groot belang. In dit verband moeten chromosomenonderzoek en DNA-doorstroomcytometrie worden genoemd, als belangrijke methoden om tot opheldering van de biologische eigenschappen van blaskanker te komen. In deze studie worden de gegevens, verkregen uit chromosomenonderzoek en meting van het DNA-gehalte van de tumorcel, beschreven. Eerste doelstelling was het ontwikkelen van een bruikbare techniek om chromosomen van zoveel mogelijk blaastumor-biopsieen te kumnen bestuderen.

In het begin van het onderzoek konden, voornamelijk na kortdurende celkweek, in $42 \%$ van de tumoren beoordeelbare chromosomen worden verkregen. Een later ontwikkelde en meer betrouwbare methode, eveneens in deze studie beschreven, leverde in $93 \%$ van de tumoren beoordeelbare chromosomen op. Verder bleken voor gebruik in doorstroomcytometrie en chromosomenonderzoek tumoren die mechanisch tot celsuspensies waren bewerkt geschikter dan enzymatisch verkregen celsuspensies. De gegevens, verkregen uit chromosomenonderzoek, werden gecorreleerd aan gegevens over het tumorstadium en de tumorgraad, alsmede met gegevens over het klinisch verioop van de tumor. In niet-infiltrerende tumoren ( $\mathrm{Ta}$ ) werden voornamelijk cellen met een nagenoeg diploid chromosomenaantal ( $\leqslant 49$ chromosomen) aangetroffen. Daarentegen werden in infiltrerende tumoren (T1-T4) voornamelijk hyperdiploide chromosomenaantallen $(>49)$ aangetroffen.

In goed gedifferentieerde tumoren (G1) waren bijna alle cellen nagenoeg diploid ( $\leqslant 49$ ), terwijl deze in slecht gedifferentieerde tumoren (G3) bijna allen hy perdiploid (>49) waren. In de groep der $\mathrm{G} 2$-tumoren, waren zowel diploide als hyperdiploide chromosomenaantallen aanwezig. Vervolgens bleek dat tumoren met een nagenoeg diploid chromosomenaantal veel later recidiveren dan tumoren die hyperdiploid zijn. Progressie komt significant vaker voor bij hyperdiploide dan bij nagenoeg diploide tumoren.

Tijdens het onderzoek bleek ook dat het oplossend vermogen van doorstroomcytometrie verbeterde als aan de te onderzoeken tumorcellen anti-lichamen tegen cytokeratine werden gehecht. Bovendien kon door aanhechting van deze anti-lichamen het percentage cellen in de onderscheiden fasen van de celcyclus betrouwbaar vastgesteld worden. Helaas konden tumorcellen met een abnormaal karyotype, maar met een (nagenoeg) diploid chromosomenaantal, met behulp van doorstroomcytometrie niet van normale cellen onderscheiden worden.

Door bandering konden non-randon chromosomenafwijkingen in de tumorcellen worden vastgesteld. Het verlies van chromosoom nummer 9 en het verlies van een deel van chromosoom nummer 10 lijken primaire chromosomenafwijkingen in de ontwikkeling van de blaastumor. Afwijkingen in aantal of structuur van de chromosomen nummers $1,7,11$ en 17 zijn mogelijk secundaire gebeurtenissen in de ontwikkeling van kanker van de urineblaas. 


\section{Acknowledgements}

This thesis could not have been realized without the help of many others. I wish to express my gratitude and acknowledgements to:

- Co-authors of the articles and those I have mentioned in the acknowledgements of the separate articles of this thesis for excellent cooperation for many years.

- Mr. Drs. Ton Ederveen and Drs. Jan Noten, heads of the laboratories, for the energy spent to realize the unhampered continuation of this research.

- Mr. Jac Haegens, chief technician, for his help in the development of technical procedures.

- Miss Carolien Bouten for her excellent secretarial work and critical preparation of the manuscript.

- Mr. Drs. Anton Kroft, for his support both during and after his impressive career in the P.C.V.-hospital.

- The board of directors of the grammar school "Jerusalem" for their cooperation.

- Mr. Anton Uyterwaal, biologist of "Jerusalem" for sharing responsibility if necessary.

- Mr. Drs. Toon den Brok, for his extraordinary skill in the art of photography.

- Mrs. Drs. Mieke Ederveen-Lucas for emendation of the english texts.

I particularly wish to thank my parents for enabling me to have this university education and my wife Winy and our three daughters for their patience, understanding and support. 


\section{Curriculum vitae}

The author of this thesis was born in Limbricht, the Netherlands on January 30th 1941 . He altended High School and afterwards the Agriculture College in Roermond where he took his finals in 1960 .

He started studying Biology at Nijmegen University and graduated as a biologist in 1966 . In 1.965 he started teaching biology, first in Nijmegen and from 1966 onwards at the Grammar School "Jerusalem" Venray.

From 1967 he combined his teaching profession with work as a cytogeneticist with the "Stichting Ziekenhuisapotheek en Klinisch Laboratorium Venray".

In 1971 he continued his studies and graduated at Utrecht University in 1973. His main subject was genetics and his minors were general botany and endocrinology.

In 1980, in combination with his activities as mentioned before, he started working on the present thesis in the laboratories of the "Stichting Ziekenhuisapotheek en Klinisch Laboratorium Venray" and with facilities of the Catholic University Nijmegen and the State University Limburg. 